\title{
RECONSTRUCTING A BUILDING OF HISTORIC SIGNIFICANCE WITHIN CURRENT REGULATORY CONTEXT
}

Focusing on Frank Lloyd Wright's Banff Pavilion

\author{
by \\ Sadek Taha
}

B.A.Sc., École Polytechnique de Montréal, Quebec, Canada, 2017

\author{
A Major Research Project \\ presented to Ryerson University \\ in partial fulfillment of the requirements for the degree of \\ Master of Building Science \\ in the program of \\ Building Science
}

Toronto, Ontario, Canada, 2020

CSadek Taha 2020 


\section{AUTHOR'S DECLARATION}

I hereby declare that I am the sole author of this MRP. This is a true copy of the MRP, including any required final revisions.

I authorize Ryerson University to lend this MRP to other institutions or individuals for the purpose of scholarly research.

I further authorize Ryerson University to reproduce this MRP by photocopying or by other means, in total or in part, at the request of other institutions or individuals for the purpose of scholarly research.

I understand that my MRP may be made electronically available to the public. 


\section{Reconstructing a Building of Historic Significance with Current Regulatory Context Focusing on Frank Lloyd Wright's Banff Pavilion \\ Sadek Taha \\ Master of Science, 2020 \\ Building Science, Ryerson University}

\section{ABSTRACT}

The issue of how to reconstruct buildings with historic significance that have been damaged or demolished has been an important matter in places that have encountered warfare or natural disasters. Reconstructing a heritage building requires deep understanding of the significance of its characterdefining elements. In most of cases, it also requires adaptation and compliance to current codes, standards and regulations particularly if the building is to maintain its use. In this report, the reconstruction process is examined in two parts: assessing the principles governing the significance of historical value and applying those principles in a regulatory framework to the redesign of a demolished building. The Banff Pavilion in Alberta, a building originally designed by esteemed architect Frank Lloyd Wright (FLW) was chosen for the study. Conclusions of the first part showed how the assessment of the historic, cultural, aesthetic, social and spiritual value of buildings is specific to time and place. The second part outlined the process of reconstruction design within a Building Code framework and showed how applying the Building Code to the reconstruction of Banff Pavilion influences the preservation of some character-defining elements. In sum, this research will help heritage restoration practitioners in

understanding the challenges posed to meet current regulatory requirements in heritage building restoration. Although the process was only applied to parts of the building envelope, more investigation is needed in other building elements such as the HVAC or the structural systems.

\section{P.S. All italicized text is a direct quote extracted from an external referenced source.}




\section{ACKNOWLEDGEMENTS}

I want to thank God for giving me such a loving family, to my mother who was always supportive and encouraging, and to my father, who inspired my interest in culture and history.

To the professors at Ryerson University for teaching me the field of building science with such passion. A special thanks to the Frank Lloyd Wright Banff Pavilion revival team at Ryerson, to my supervisor Hitesh Doshi, Yew-Thong Leong my second reader, and to the late Kendra Smith with her kind being.

To my friends and fellow students at Ryerson, with whom I shared amazing moments and remarkable learning experiences.

Finally, to all those who have inspired the preservation of heritage in the social, scientific and political realm, those who gave meaning to this research. 


\section{DEDICATION}

I dedicate this work to The Most Merciful in the following verse of the Holy Quran:

"O people! We created you from a male and a female, and made you races and tribes, that you may know one another. The best among you in the sight of God is the most righteous. God is AllKnowing, Well-Experienced" [49:13]

I hope that exploring the heritage among cultures will be a step towards worldwide self-awareness, compassion, and respect. Indeed, the preservation of heritage is a universal value that benefits all humankind. 


\section{TABLE OF CONTENT}

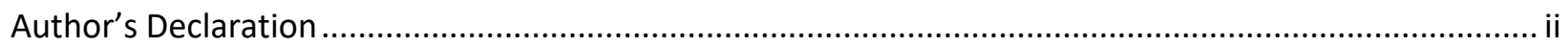

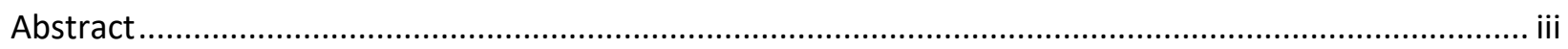

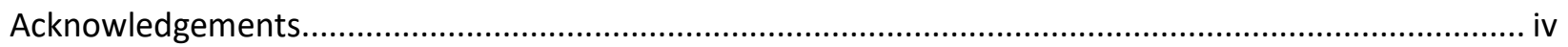

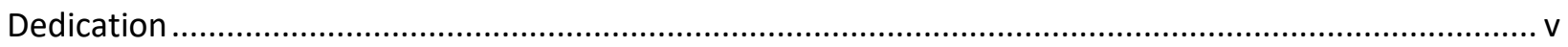

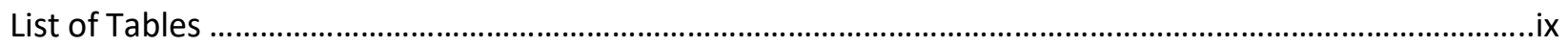

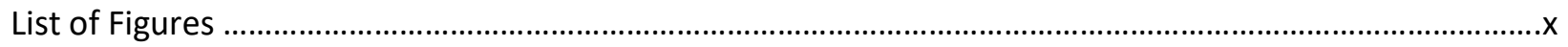

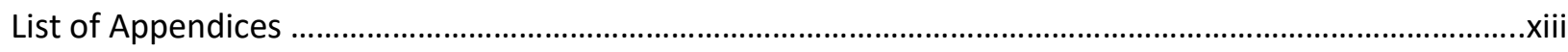

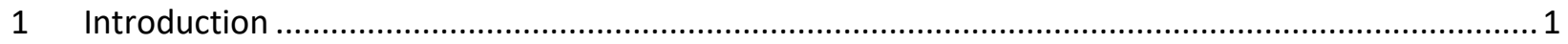

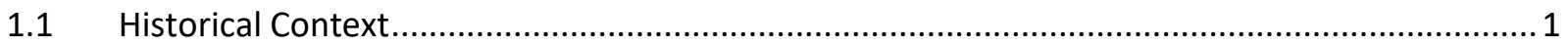

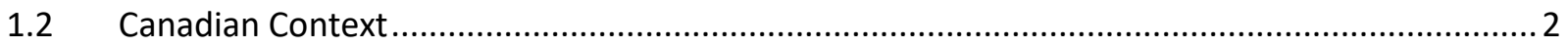

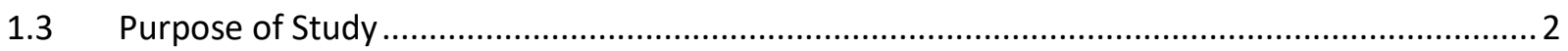

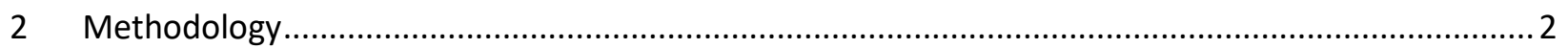

3 Part 1 - Determining the Principles Governing Reconstruction ...................................................... 3

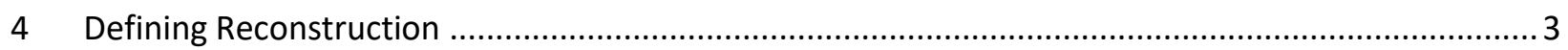

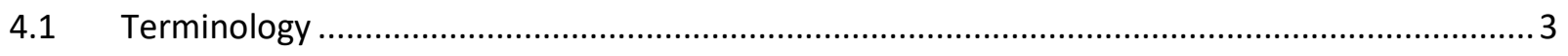

4.2 Reconstruction as a "complete restoration" .................................................................... 5

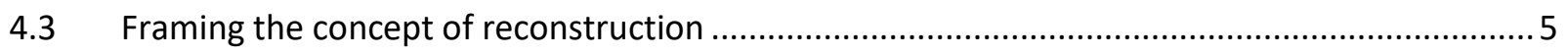

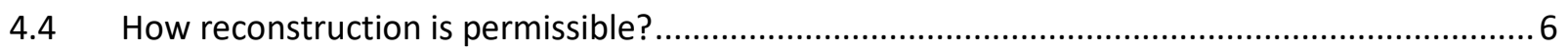

4.5 Reconstruction within the Canadian Framework ........................................................ 7

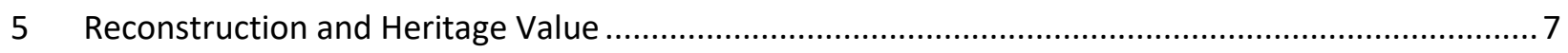

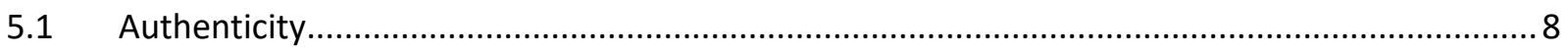

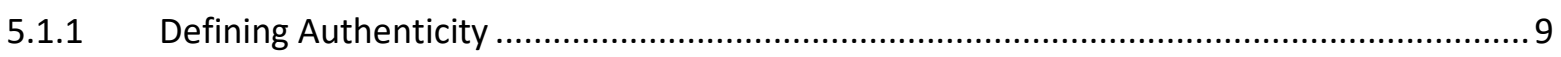

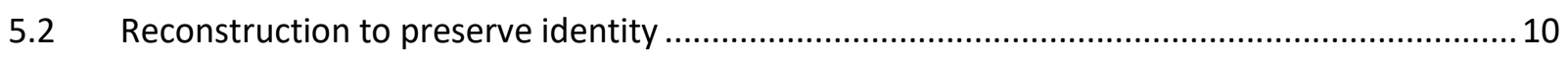

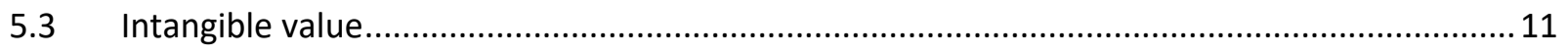

5.3.1 Conservation of the Diamond Sutra on the Sacred Mount Tai, China............................. 12 
5.3.2 The 1300 years old Cyclic Renewal of Shrines in Ise, Japan......................................... 12

5.3.3 Craftsmanship practices in the conservation of the Mosque in Djenné, Mali...................14

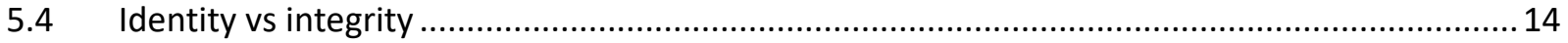

5.4.1 Rebuilding (1898-1908) and Reconstruction (1952-1953) - The Kinkaku-ji Temple in Kyoto, Japan 15

5.4.2 Restoration - The Kandinsky/Klee Meisterhaus in Dessau, Germany ............................. 16

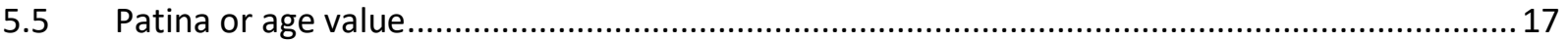

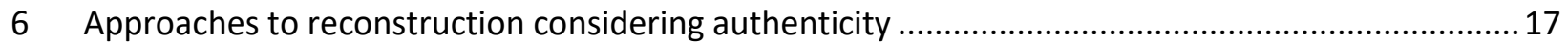

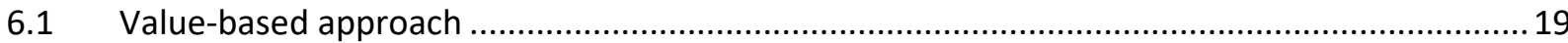

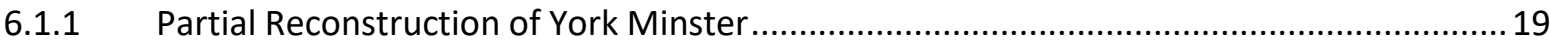

6.1.2 Partial Reconstruction of Uppark House and Garden................................................ 20

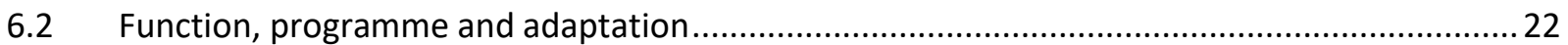

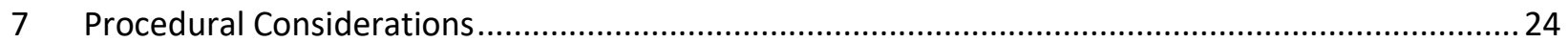

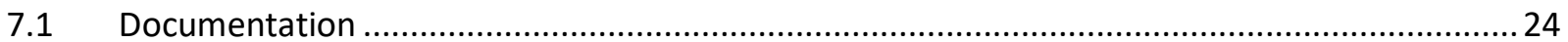

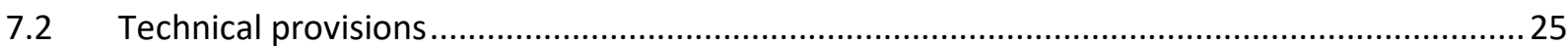

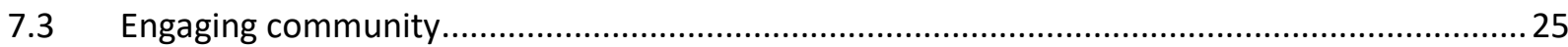

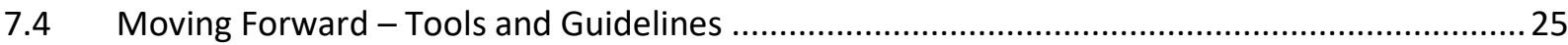

7.4.1 Digital technologies to improve the conservation process.............................................. 25

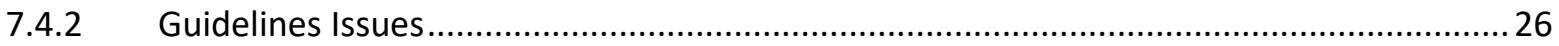

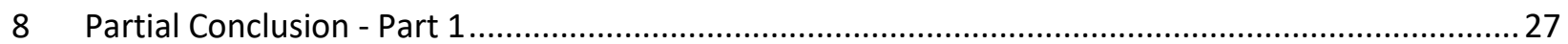

9 Part 2 - Designing heritage building components while complying with current codes and

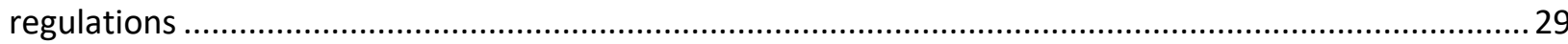

10 Outlining the process of redesign within the Building Code …..............................................29

10.1 Understanding the heritage value using a Statement of Significance ....................................29

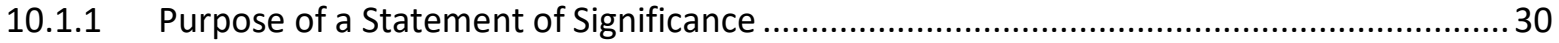

10.2 Character-Defining Elements and their Implications on the Building Code Requirements ........30 
10.3 Determining the Constructional Approach .................................................................... 31

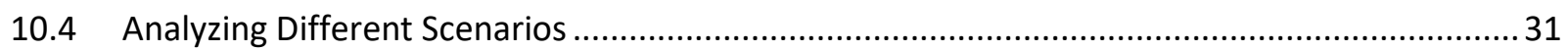

11 Applying the process to the partial redesign of the Banff Pavilion ........................................... 31

11.1 Understanding the heritage value using a Statement of Significance ..................................... 31

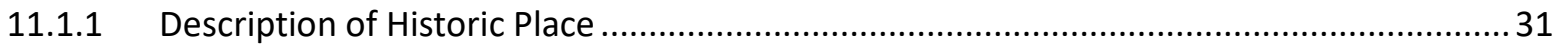

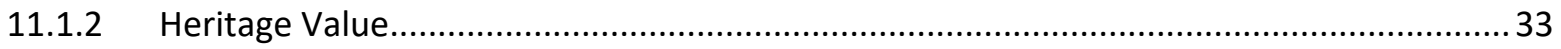

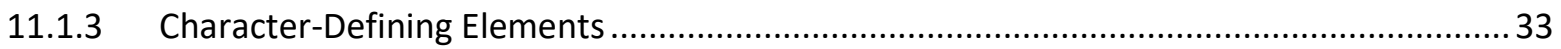

11.2 Character-Defining Elements and their Implications on the Building Code Requirements ....... 40

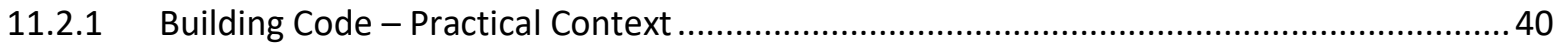

11.2.2 Concerned Parts of the Building Code ....................................................................... 41

11.2.3 Character-Defining Elements in Relation to Some Areas of Part 3, 5, 6 and 9............... 41

11.2.4 Character-Defining Elements in Relation to Specific Building Envelope Requirements..... 43

11.2.5 Prescriptive Building Envelope Option............................................................... 44

11.3 Constructional Approach to Wood-frame Walls and Roof Assemblies .................................. 45

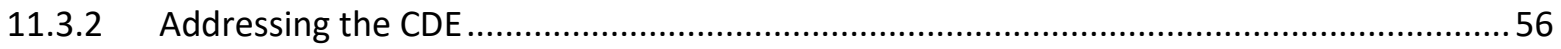

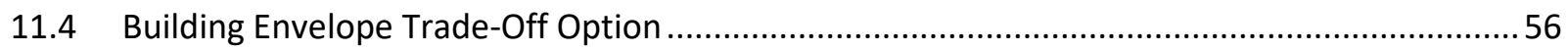

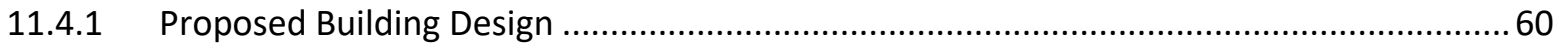

11.5 Discussion over the Building Envelope Challenges ............................................................66

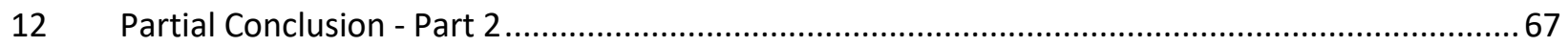

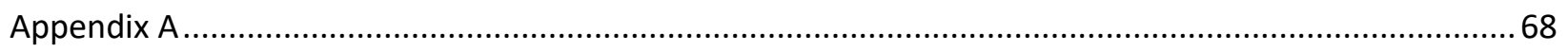

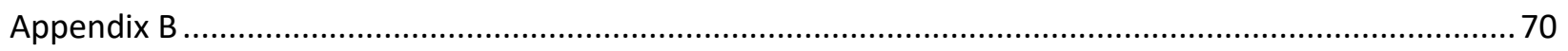

B1 Compliance with Part 3 - Fire Protection, Occupant Safety and Accessibility ................................70

B2 Compliance with Part 5 - Environmental Separation ............................................................. 73

B3 Compliance with Part 6 - Heating, Ventilating and Air-Conditioning .......................................... 76

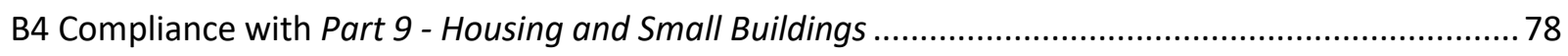

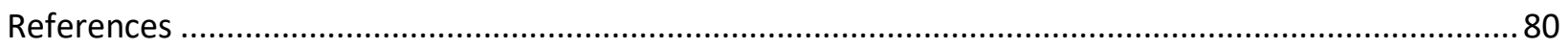




\section{LIST OF TABLES}

Table 1 Building Envelope minimum requirements for non-residential occupancy as per ASHRAE 90.1 and

SB-10 [59],[61]. 44

Table 2 Various insulation types with R-value range, vapour permeability, and air permeability [62]..... 46 Table 3 The thermal resistance for various installed insulation options in $2 \times 6$ wood frame walls and their corresponding minimum thickness to comply with prescriptive requirements

Table 4 The thermal resistance for various installed insulation options in roof assemblies and their corresponding minimum thickness to comply with prescriptive requirements....................................52

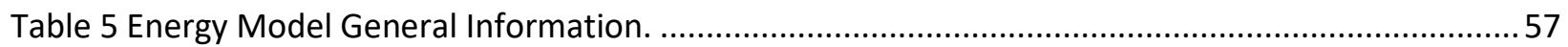

Table 6 3D Energy Modelling Information - Prescriptive Requirements based on Appendix A Rated values.

Table 7 Assembly properties of the modelled baseline wood-frame wall.

Table 8 Heat transfer properties of the modelled baseline wood-frame wall. ....................................... 59

Table 9 Assembly properties of the modelled baseline roof................................................................ 59

Table 10 Heat transfer properties of the modelled baseline roof..........................................................59

Table 11 Modelled building window to wall area ratio and skylight to roof area ratio...........................60

Table 12 Building envelope differences between the baseline building and the proposed building. .......61

Table 13 Building envelope differences between the baseline, proposed building, and the modified proposed building. 


\section{LIST OF FIGURES}

Figure 1 Painting of the Cracow Suburb in Warsaw, Poland by Bernardo Bellotto (1768) [21]................11

Figure 2 Panoramic view of Stone Sutra on the Sacred Mount Tai, China [25] ...................................... 12

Figure 3 Sanctuary of the outer shrine in Ise, after its partial reconstruction (1993) [26].....................13

Figure 4 The Great Mosque of Djenné, Mali. The massive walls are erected by sun-dried mud bricks with

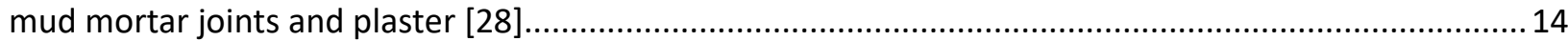

Figure 5 The Kinkaku-ji Temple in Kyoto, Japan [31] ........................................................................ 15

Figure 6 The Kandinsky/Klee Meisterhaus in Dessau, Germany, 1926 [32]..........................................16

Figure 7 Staircase, Kandinsky/Klee Masters' house, Dessau, July 2010 [33] ........................................17

Figure 8 Royal Ontario Museum in Toronto, Canada [36].................................................................. 18

Figure 9 York Minster south vault destroyed by a fire in 1984 [37] .................................................. 19

Figure 10 York Minster cathedral after restoration of the roof [38] ......................................................2 20

Figure 11 South Transept Vault, York Minster, as seen in 1965 (left) [39] and rebuilt after the fire in 1984

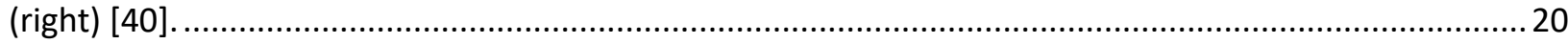

Figure 12 View of Uppark by Pieter Tillemans, circa 1728-30 [41]...................................................21

Figure 13 At Uppark, some burnt details were left unpainted to show where the old and new meet [43].

Figure 14 A plasterer working on the reinstatement of the ceiling of the Red Drawing Room at Uppark [43].

Figure 15 Reconstructed envelope on the Battersea Arts Centre using original salvaged bricks [44]...... 22

Figure 16 New timber lattice ceiling at the Battersea Arts Centre [45] .............................................2 23

Figure $17 \mathrm{~A}$ detail section of the Grand Hall in Battersea Arts Centre [44] ..........................................2 23

Figure 18 The Marketplace of the Old Town (Stare Miasto) of Warsaw following the WWII attacks (left), and following reconstruction (right) [46].

Figure 19 A 3D computer model can image surface detail and texture with stunning accuracy, an important

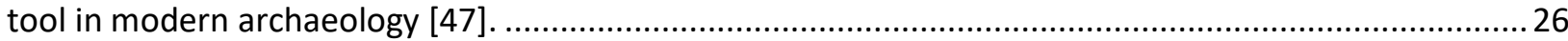

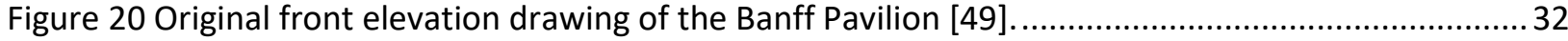

Figure 21 Banff Pavilion architectural modelling by a team of students at Ryerson University led by Pr. Yew-Thong Leong [1] 32

Figure 22 Frank Lloyd Wright's River Forest Tennis Club (RFTC) as seen in 1906 [50]. Strong similarities are observed between the RFTC and the Banff Pavilion. .33 
Figure 23 Banff Pavilion layout and key elements [49]. .35

Figure 24 Plan drawing showing possible tennis court proportion in the Banff Pavilion design [53]........ 35

Figure 25 Elevation drawing showing possible tennis court proportion in the Banff Pavilion design [53].35

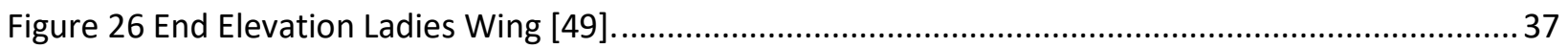

Figure 27 Door and sash design from the Banff Pavilion front elevation [49]. ...................................... 37

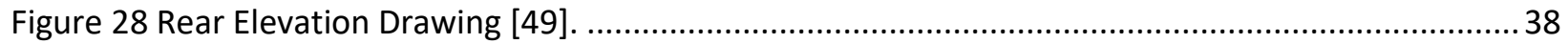

Figure 29 The original Banff Pavilion viewed from inside (left) [55] and a 3D model rendering (right) [1].

Figure 30 Cross section thro pavilion showing natural passive ventilation system [49]........................ 40

Figure 31 Cross section thro pavilion showing open ventilation system under the terrace [49]..............40

Figure 32 Cut section on the east side of the Banff Pavilion showing the slope ( 1 in 6 ) of the roof in an east-west axis.

Figure 33 Elevation on the west side of the building showing the slope (1 in 6) of the roof in a south-north axis.

Figure 34 Typical above-grade wood-frame wall assemblies with different insulation types [62]...........47

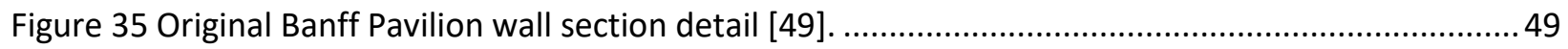

Figure 36 Overview summarizing XPS on 2x6 wood frame wall construction [64]............................... 49

Figure 37 Overview summarizing spray foam on $2 \times 6$ wood frame wall construction [65]......................50

Figure 38 Overview summarizing 2x6 wood-frame wall assembly with mineral fiber insulation boards [66].

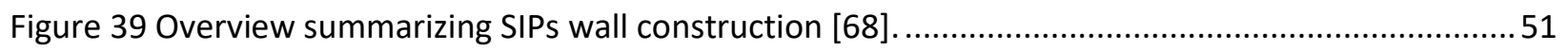

Figure 40 Original Banff Pavilion roof section detail [49] ................................................................. 53

Figure 41 Compact unvented roof assembly using fiberglass cavity insulation and continuous rigid

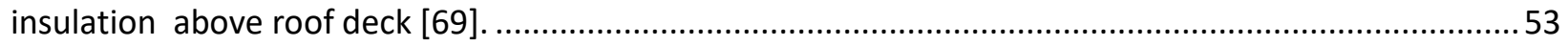

Figure 42 Compact unvented roof assembly using High density spray foam cavity insulation and continuous rigid insulation above roof deck [69]. .54

Figure 43 Compact unvented roof assembly with continuous rigid insulation entirely above roof deck [69]. 54

Figure 44 The unvented "under-roof" is topped with a vented "over-roof" to control ice-damming [70]. 55

Figure 45 Pitched roof assembly with unvented "under-roof" is topped with a vented "over-roof" [62].55 
Figure 46 Pitched roof assembly showing the impact of the layers of insulation on the aesthetics of the

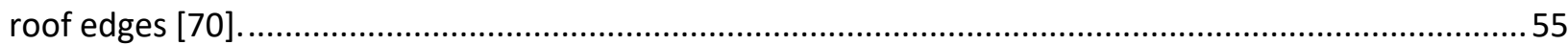

Figure 47 A 3D model of the Banff Pavilion original design which serves as trade-off proposed building. .

Figure 48 The 3D model of the Banff Pavilion original design after dimensions simplifications...............57

Figure 49 Energy consumption output for baseline and proposed building. .........................................62

Figure 50 Energy consumption output for baseline and the upgraded proposed building. .....................65 


\section{LIST OF APPENDICES}

\section{Appendix A}

Figure A- 1 Floodproofing scenarios considered for the Farnsworth House in Chicago [71]...................68

Figure A- 2 Original section drawing of the Banff Pavilion in an east-west axis [49].............................69

Figure A- 3 Original section drawing of the Banff Pavilion in a north-south axis [49]............................69

Table A- 1 Building envelope assembly minimum effective R-value by climate zone and heating degree day (HDD), as required by the 2011 National Energy Code for Buildings [62] ...........................................68 Table A- 2 High performance wood-frame building envelopes with effective R-value targets for compliance with energy standards [62]. 69

\section{Appendix B}

Table B- 1 Compliance with Part 3 - Fire Protection, Occupant Safety and Accessibility .......................... 70

Table B- 2 Compliance with Part 5 - Environmental Separation ............................................................. 73

Table B- 3 Compliance with Part 6 Heating, Ventilating and Air-Conditioning ........................................ 76

Table B- 4 Compliance with Part 9 - Housing and Small Buildings ......................................................... 78 


\section{INTRODUCTION}

Our physical environment often contains valuable and influential elements. Monuments, for example, have been considered a source of inspiration for many generations. All over the world, people put value in buildings of historical significance and consider them as a living legacy. Often targeted by devastating events, the preservation of monuments has always been a challenge in front of warfare, natural disasters or simply the ageing of fabric. In Europe, the Second World War impacted society's connection to monuments. Eventually, the relationship between the physical and social environment was getting more and more attention to communities around the world. The $20^{\text {th }}$ century has seen important charters and conventions addressing the conservation and restoration of heritage monuments and sites. However, there are missing pieces concerning the process of reconstruction of lost heritage buildings. This document aims at determining typical challenges related to the process of heritage buildings reconstruction. The study is divided into two sections, one being more qualitative and the other focusing on the quantitative aspect of building design. First, it will aim at assessing the principles governing heritage buildings reconstruction. Second, the document will outline a design process of heritage building elements in compliance with the current regulatory context. The process will then be applied to a specific building, namely the Banff Pavilion in Alberta, a building designed and constructed in 1914 by the famous architect Frank Lloyd Wright and demolished in 1938 after being subject to flood and decay.

\subsection{Historical Context}

The Venice Charter (1964), the Burra Charter (1979) and the Riga Charter (2000) are the fundamental documents that will help narrowing down the specific definition of the concept of reconstruction and how it is permissible [2].

The International Charter for the Conservation and Restoration of Monuments and Sites, also known as the Venice Charter, was adopted in Venice in 1964 by the Second International Congress of Architects and Technicians of Historic Monuments [3]. The Venice Charter is considered by the conservation community as the essential modern doctrinal guide for interventions to built heritage [4]. The charter was the foundation stone for the International Council on Monuments and Sites (ICOMOS), which aimed to "encourage the adoption and implementation of international recommendations concerning monuments, groups of buildings and sites" [5].

Furthermore, the Australia ICOMOS Charter for Places of Cultural Significance, otherwise called Burra Charter, was first adopted in 1979 in Australia, and aimed to guide the conservation and management of 
places of cultural significance [6]. The Burra charter explicitly defined the concept of restoration and reconstruction.

In October 2000, an international forum occurred in Riga, Latvia, which lead to the Riga Charter on Authenticity and Historical Reconstruction in Relationship with Cultural Heritage [4]. The goal was to establish guidelines for "heritage conservation authorities to defend heritage values and principles in instances where inappropriate reconstructions had been proposed" [4].

\subsection{Canadian Context}

The Standards and Guidelines for the Conservation of Historic Places in Canada is a benchmarking guide for the conservation of heritage resources, published by Canada's Historic Places. The document presents goal-oriented guidelines for appropriate decision-making for different conservation measures on historic place. It does not replace the task of conservation practitioners nor does it include precise technical provisions that can be applied in any context [7]. Various levels of authority adopted the document as a reference for evaluating prospective conservation work on a heritage building's key elements.

\subsection{Purpose of Study}

Although many international documents such as the International Council on Monuments and Sites (ICOMOS) addressed principles of reconstruction, there have been no clear guidelines to which heritage professionals can directly refer [8]. The areas of concern are typically related to the principles governing reconstruction as well as the guidelines in place to implement them within a regulatory context.

The goal of this study is far from establishing a universal definition of how to perform the reconstruction of lost heritage. Instead, it aims at defining a practical pattern when reconstruction of heritage buildings takes place, considering the arguments of value that are determined by subjective interpretations as well as philosophical, social and historical realities. Indeed, the study is more of a practical analysis of the critical concepts ruling the process of reconstructing a heritage building within current regulatory context involving the National Building Code (NBC) of Canada and its related standards.

\section{METHODOLOGY}

When thinking about conservation, one should note the difference between two concepts: the purpose and the method. The purpose is the philosophy of preservation, and the methods are the principles governing the process [9]. The study will analyze worldwide concepts governing the philosophy of restoration. These concepts often regulate further methods of reconstruction within a case-specific 
framework. The first part will define reconstruction, determine the various heritage values, identify reconstruction approaches, and assess the procedural considerations in works of reconstruction. This part will deal with common conservation practices all over the world without involving a detailed technical analysis.

The second part of this study will aim at implementing current regulations for a North American reconstruction project. In order to proceed, part of the background work was interviews done with Canadian heritage professionals to identify the challenges of the process of restoration. Mainly, the analysis examines codes and standards of interest within a Canadian framework of regulations which involves the National Building Code of Canada (NBC). The second part is set into two sections by outlining the process of heritage building design within the Building Code and applying the process to the partial redesign of Frank Lloyd Wright's Banff Pavilion, a prairie-style picnic shelter built in Alberta in 1914 and demolished in 1938 due to flood problems. Currently, a group of researchers from Ryerson University in Toronto are looking into the reconstruction of the building. The document will analyze areas of concern that designers may face when complying with today's codes and standards while preserving the heritage character of a building. Although the Banff Pavilion is located in Alberta and because of familiarity and accessibility to the Ontario Building Code $(O B C)$, it will be more convenient to use it as a reference. Also, both the Ontario Building Code (OBC) and the Alberta Building Code are based on the National Building Code (NBC), which makes it acceptable to use the OBC for this study [10]. Besides, the OBC will sometimes refer to the National Energy Code of Canada for Buildings (2011) as well as the Energy Standard for Buildings Except Low-Rise Residential Buildings (ANSI/ASHRAE/IES 90.1-2010). Finally, the primary tool used for compliance with energy requirements is the DesignBuilder software.

\section{PART 1 - DETERMINING THE PRINCIPLES GOVERNING RECONSTRUCTION}

\section{DEFINING RECONSTRUCTION}

\subsection{Terminology}

Before approaching the concept of reconstruction, it is relevant to assess the variety of terms used worldwide to describe the processes governing heritage conservation. This section presents some of 
them, and it is noted that some terms are not exclusive of others and that some definitions may be different among countries.

Anastylosis: The act of reassembling existing but dismembered parts, reinstating any original fragments ensuring that the use of new materials is recognizable $[9,8]$.

Conservation: A "physical intervention in the actual fabric of the building to ensure its continued structural integrity" [11]. The Australia ICOMOS Burra Charter expresses that conservation includes "all the processes of looking after a place so as to retain its cultural significance", including repair and restoration [6]. It is the act of preserving from destructive influences and decay so as to preserve the significant form and appearance of the building, using original material when possible but allowing for the insertion of new materials. Canada's Historic Places considers that conservation can include a combination of other concepts such as preservation, rehabilitation, and/or restoration [7].

Preservation: The "maintenance of the artifact in the same physical condition as when it was received by the curatorial agency" [11]. Canada's Historic Places defines preservation as the means for "creating or maintaining a stable environment for the character-defining elements to extend their physical life" and can "include both short-term and interim measures to protect or stabilize the place, as well as long-term actions to stave off deterioration or prevent damage" [7]. The U.S. Guidelines further emphasizes that preservation should promote maintenance and repair over renewal of historic fabric [12].

Relocation (dismantling and rebuilding): Relocation of buildings is not explicitly addressed by the Venice Charter, but it requires the following: "the moving of all or part of a monument cannot be allowed except where the safeguarding of that monument demands it or where it is justified by national or international interest of paramount importance" [8]. This practice has sometimes been adopted for educational purposes or museums.

Repristination: Defined as the restoration to the original state, disregarding later accretions [8]. However, it is noted that the Venice Charter necessitates that "the valid contributions of all periods to the building of a monument must be respected, since unity of style is not the aim of a restoration" [3].

Rehabilitation: Acknowledges the buildings need to have an alternative or continuing use by means of "repair, alterations, and additions while preserving those portions or features which convey its historical, cultural, or architectural values" [12]. 
Replication: Duplicating "an existing building is an attempt to form an exact copy and therefore constitutes not just the majority of the fabric but the whole fabric" [8]. It may be practical when it is used for educational purposes or interpretation and display purposes. Replication is sometimes used to protect an original work of art when preservation is not possible [8].

Recreation: Reconstructing an existing building that has been intentionally removed in order to produce a modernized version with the same look, except the patina of age, as the original [9].

Instauration: The action of restoring elements after decay, lapse, dilapidation or loss. It is distinguished from restoration as it means specifically to renew [8]. It may involve building anew in the same or another place to replicate traditional appearances. There are no established guidelines for instauration [8].

\subsection{Reconstruction as a "complete restoration"}

The actions of restoration, recreation, instauration and replication are all terms that have common grounds with the concept of reconstruction. Perhaps the one that is more of interest is restoration, as it is used in many guidelines and is very close to the concept of reconstruction.

The Venice Charter describes restoration as the aim "to preserve and reveal the aesthetic and historic value of the monument" based on recognition of original fabric and irrefutable documentation [8]. The Burra Charter describes it as "returning the existing fabric of a place to a known earlier state by removing accretions or by reassembling existing components without the introduction of new material" [6]. The U.S. Guidelines authorize "the depiction of a building at a particular time in its history by preserving materials, features, finishes, and spaces from its period of significance and removing those from other periods" [12]. It allows limited upgrading to systems such as the "mechanical, electrical, and plumbing systems and other code-required work to make properties functional" [12]. The charters defining restoration do not explicitly describe reconstruction or what can be framed as the "complete restoration" of a building [12].

\subsection{Framing the concept of reconstruction}

Defining reconstruction is a matter that is specific to each country. The U.S. Department of the Interior National Park Service describes reconstruction as "the act or process of depicting, employing new construction, the form, features, and detailing of a non-surviving site, landscape, building, structure, or object for the purpose of replicating its appearance at a specific period of time and in its historic location" [12]. The literal meaning of reconstruction would be "to construct anew" [13]. However, The European Association for Architectural Education expresses that rebuilding does not automatically imply a precise 
and accurate recreation. The concept involves a new construction with a design appropriate to the original epoch but at the same time adjusted to the actual context [13]. Perhaps one of reconstruction objectives, similar to restoration, is to instore a place's socio-economic status to a previous period. This requires a cognitive process of evoking characters and reviving an identity, which can be reasonably complex and indefinitely subjective [13]. The "historicist reconstruction" approach implies that rebuilding is in the same form and with the same appearance as before. Reconstruction is mainly differentiated from restoration by allowing for integrating new material.

\subsection{How reconstruction is permissible?}

Reconstruction has been argued among historians, archeologists, and preservationists within their respective fields. Surrounding reconstruction of historic buildings, arguments were raised questioning the ethical aspect of reconstruction and whether it is justifiable or not to reconstruct buildings to satisfy the general public. The arguments raise the question reconstructions that may not be accurately represent the original monuments. In the 1840s, a powerful voice against reconstruction was the British writer John Ruskin (1819-1900), who advanced arguments against restorations and prompted the aim to preserve the patina of age that has its imprints on the fabric [14]. Ruskin described that societies that did not hold a long lasting fabric culture in architecture may be claimed to "die daily". He expressed that restoration is "a destruction accompanied with false description of the thing destroyed" [15], that the spirit of a monument "is given only by the hand and eye of the workman" [15], which cannot be recreated. He further notes that "Another spirit may be given by another time, and it is then a new building; but the spirit of the dead workman cannot be summoned up, and commanded to direct other hands, and other thoughts" [15].

Until the 1980s, some European countries did not consider reconstruction as an acceptable approach. They viewed it as a distortion of the past based on the accurate interpretation of the principles cherished in the ICOMOS Venice Charter [9].

In 1976, through a recommendation regarding the Safeguarding and Contemporary Role of Historic Areas, the UNESCO insisted that: "throughout the world, under the pretext of expansion or modernization, demolition ignorant of what it is demolishing and irrational and inappropriate reconstruction work is causing serious damage to this historic heritage" [16]. Heritage professionals have relied on the Venice Charter (Venice 1964) on The Conservation and Restoration of Monuments and Sites ass a default starting point for concerns about reconstruction. 
The Riga Charter on Authenticity and Historical Reconstruction permitted reconstruction by acknowledging that "replication of cultural heritage is in general a misrepresentation of evidence of the past but that in exceptional circumstances, reconstruction of cultural heritage, lost through disaster may be acceptable, when the monument concerned has outstanding artistic, symbolic or environmental significance for regional history and cultures" [4].

Hence, reconstruction is permitted where it is inevitable for the durability of a damaged site and where it reinstates the relevance of a place [4, 5]. The ICOMOS New Zealand Charter permits reconstruction when it is imperative to the "function, integrity, intangible value, or understanding of a place" [17]. Reconstruction is not allowed to be speculative but based on strict, exhaustive, and undeniable documentation $[4,5,17]$.

\subsection{Reconstruction within the Canadian Framework}

Canada's Historic Places considers conservation as the leading term for safeguarding historic places. It outlines it as "all actions or processes aimed at safeguarding the character-defining elements of an historic place to retain its heritage value and extend its physical life" [7]. The approach revolves around three actions, namely: Preservation, Rehabilitation, and Restoration.

Hence, reconstruction is not addressed in the Canadian standard, as it is "not considered conservation and is therefore not addressed" [7]. However, within the North American context, the U.S. Secretary of the Interior's Standards for the Treatment of Historic Properties provides qualitative guidelines that include reconstruction of heritage buildings [12].

Unlike restoration, there seems to be a global consensus over the concept of conservation [9]. Although the same words can be defined differently among legislations and cultures and knowing that the boundaries between conservation and preservation are challenging to clarify, conservation will be the term used in this report to describe the aim of safeguarding historic places.

\section{RECONSTRUCTION AND HERITAGE VALUE}

As the Nara Document expresses, assessing values surrounding cultural sites may diverge from culture to culture. The idea of a generic criterion in heritage revival is not realistic since monuments need to be interpreted within their respective cultural context. In fact, the New Zealand Charter gives importance to identifying and taking into account all aspects of a site's "cultural heritage value without unwarranted 
emphasis on any one value at the expense of others" [17]. Moreover, the World Heritage Convention Operational Guidelines emphasize that recognizing value is highly dependant on the accuracy and authenticity of documentation [8]. In addition, the Declaration of San Antonio identifies five possible "indicators of authenticity" that describe the values inherited in a site:

"reflection of the true value of a site derived from all its significant history; integrity in terms of its level of completeness; whether the context and/or environment corresponds to the original or other periods of significance; identity in terms of how the local population identify with the site and whose identity it reflects; and the traditional patterns of use and function that have characterized the site" [18].

The Burra Charter brought a broad and complex notion stating that "Cultural significance means aesthetic, historic, scientific, social or spiritual value for past, present or future generations. Cultural significance is embodied in the place itself, its fabric, setting, use, associations, meanings, records, related places and related objects" [5]. In this regard, the Standards and Guidelines for the Conservation of Historic Places in Canada clarifies that the system of "values-based context" is a process that evaluates the significance of a historic place. It emphasises that the values stated above "may be singular or multiple; are subjective, wide-ranging, and can overlap; and can be assigned by different groups and may change over time" [7].

In the International Charters for Conservation and Restoration, Michael Petzet claims that the concept of authenticity in the interpretation of monuments was developed from historic material to other factors such as the "authentic spirit". Hence, the preservationist will aim at conserving authentic values of a building that may involve a "display value" that is exclusively aesthetic or a "feeling value" that aims towards reviving a specific form or situation [5].

Therefore, understanding of the concept of authenticity as well as other concepts of value will influence decision-making in reconstruction projects, which involves a variety of apparent and embodied meanings. Understanding the heritage value is the essential first step to address a successful reconstruction project.

\subsection{Authenticity}

The nineteenth century saw reflections opposing Eugène-Emmanuel Viollet-le-Duc and John Ruskin, two esteemed architectural critiques [19]. Both proponents of Gothic, Viollet-le-Duc participated in many restoration projects of the Middle Ages architectural monuments in France and viewed restoration as an opportunity to preserve, reinstate and indeed enhance [19]. As advanced before, Ruskin despised restoration practices and viewed them as totally destructive and morally offensive, he advocated for the 
aesthetic value of ruins [19]. This idea introduces the concept of authenticity, which is the bottom line of restoration strategies and interpretations of ideas of form, substance and place [9].

\subsubsection{Defining Authenticity}

The American Heritage Dictionary (2019) describes "authentic" as "Conforming to fact and therefore worthy of trust, reliance, or belief" [20]. The architectural context classifies "authenticity" as an aesthetic term giving aesthetic value meaning real, original, or genuine [14]. Reflections on the concept of authenticity raise three main aspects, namely: the aesthetic validity of a building, the aesthetic concept of the designer, and the aesthetic experience of its community [14].

The original appearance of an object is essentially related to authenticity. It is possible to break down the concepts governing authenticity by looking into the primary form of an object and the interpretations that it has been subject to overtime. For buildings, the major qualities of concern are authentic form and original fabric, which are altered overtime. Alterations may be caused by the ageing process or a human intervention to upgrade some features, without necessarily being exposed to natural or human disasters [9].

However, there exist major transcultural challenges related to the notion of authenticity since the majority of its definitions as well as their relation to credibility and truthfulness came up from an occidental cultural perspective [14]. Truthfulness is strongly related to the meanings embodied in monuments based on philosophy, beliefs, local traditions and craftsmanship. Hence, a true value cannot be framed in an objective and universal description that is able to distinguish fidelity from hypocrisy [14].

In fact, many issues arise when trying to judge about authenticity. The first issue regarding "authenticity and identity" which the Declaration of San Antonio describes as the "identification, evaluation and interpretation of their true values as perceived values by our ancestors" and current society as a progressing and disparate community [18]. The second issue concerns "authenticity and history", which implies that recognizing authenticity demands a thorough evaluation assessing the importance of a monument by groups of people who claim its heritage value. It also requires assessing the origins and evolving values of a site over a period of time. The third issue concerns "authenticity and materials" which implies that tangible aspects of value such as materials and fabric can carry a "testimonial value" of aesthetic or historic importance and convey knowledge about a community's history and identity. The fourth issue concerning "authenticity and social value" where historic places may bear spiritual meanings 
(by means of religious beliefs, traditions, customs, etc.) that save memory and conserve a sense of community, associating it to ancestral references [8].

\subsection{Reconstruction to preserve identity}

In the 1990s, hundreds of religious monuments were destroyed in western European countries. In these cases, historicist reconstruction was aimed as a sense of continuity and an affirmation of identity and encouraging those who fled the war to return home [9].

The city of Warsaw in Poland is an excellent example. The Nazis went to remove all monuments that could relate to the history and culture of the Polish nation where prominent monuments of the city such as the Royal Castle and the Central Railway Station were targeted. The reconstruction of Warsaw's Royal Castle and other buildings was aimed to protest the Nazi philosophy of annihilating a nation through the eradication of its culture. Hence, the idea of building a modern Warsaw with modern architecture on top of the old foundations was rejected. Reconstructing the character in its original form was necessary to revive memories of people and to ensure that future generations could recognize the value of the place which was embedded in its history [9].

The work of reconstruction of the Royal Castle was executed by preserving all authentic fragments among the ruins. As can be seen in Figure 1, relevant documentation was gathered, including famous paintings from the Royal Castle. These paintings were preserved by a secret action of art historian Professor Stanislaw Lorentz at the University of Warsaw. He rescued paintings by Bernardo Bellotto, showing the city through twenty-six view. These paintings were essential to the reconstruction process. Also, another important documentation were the investigations carried out before the war by the Department of Architecture of the Polytechnic University in Warsaw. As an academic exercise, they required students to make drawings of the old churches, palaces and merchant houses. This exercise included drawings of façades, sections and plans in addition to iconographic descriptions of details. These works were retrieved and deemed essential for the reconstruction process [9]. 


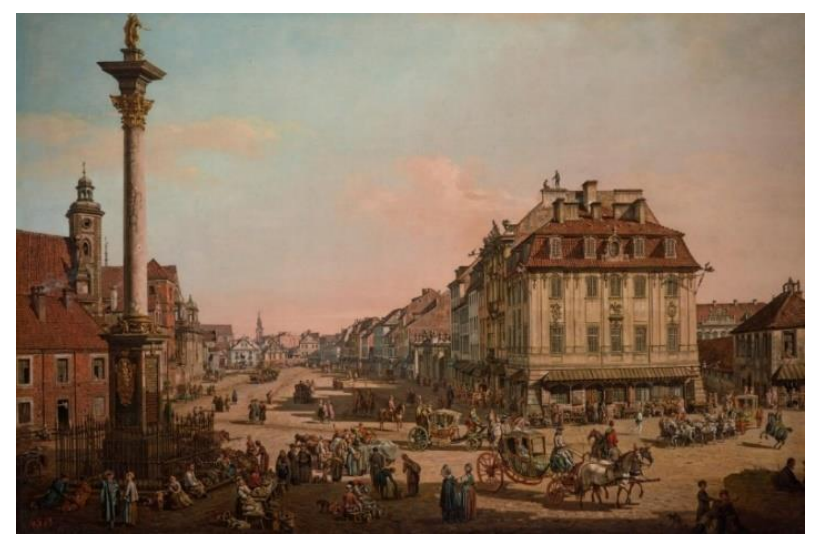

Figure 1 Painting of the Cracow Suburb in Warsaw, Poland by Bernardo Bellotto (1768) [21].

The example in Warsaw that preserving authenticity implies not only the form of the monument but also its meaning as a memorial for the next generations. In fact, with their meanings, the built environment satisfies both the appearance and socio-cultural correlations. However, this example is specific to the Polish nation, for which the preservation ideology is deeply rooted in their history [9]. These arguments also imply that authenticity cannot strictly rely on documentation, without considering other aspects that will be stated in the next sections.

\subsection{Intangible value}

It is not likely to pinpoint the values embodied in a monument's fabric without looking into other meaningful elements of significance. The Declaration of San Antonio gives importance to weighing both material fabric and distinctive immaterial meanings of a site [8]. Also, as author Michael Petzet expresses: "in the evaluation of a monument not only the oft-evoked historic fabric but also additional factors ranging from authentic form to authentic spirit play a role" [5]. Therefore, interpretation of authenticity involves tangible characters and intangible aspects in relation with a building function, craftsmanship, or rituals.

At first sight, one may think that it is possible to divide between western (Occident) and eastern (Orient) conservation practices objectively, but case studies among countries have contradicted that idea. At the same time, the Korean architectural historian Seung-Jon Chung explains that conservation principles are affected by "the spiritual and naturalistic sensibilities of East Asian culture and architecture" which contrasts fundamentally with the Western cultural tendency for "visual beauty through its material substance" [22]. In 2004, the Yamato Declaration on Integrated Approaches for Safeguarding Tangible and Intangible Cultural Heritage differentiated the notion of authenticity between tangible and intangible heritage. In the context of the intangible characters, the tangible aspect of authenticity becomes 
insignificant when the intangible aspect is "transmitted from generation to generation" and "constantly recreated by communities" [23].

Therefore, the richness of cultural practice in reconstruction should not be undermined to create a uniform conservation practice. Hence, what is deemed authentic depends on a variety of transcultural differences around the globe. The following case studies emphasize that idea.

\subsubsection{Conservation of the Diamond Sutra on the Sacred Mount Tai, China}

Traditionally, the Chinese conservation principle emphasized on language and ideas and let physical traces decay. The idea was that "old works must perish for new one to take their place" [24]. However, this principle was altered as conservation strategies have transformed remarkably. The conservation of the Diamond Sutra in Stone at Mount Tai is an example expressing the intangible value of a place (see Figure 2). The rock surface was carved with 2478 characters and were under constant erosion by the water flowing over it, which ended with a remaining 241 characters only. In fact, the value was in its eternal validity that was embodied in the "babbling brook" of the stream flowing over the carved inscriptions symbolizing "the perpetual reading of the text that keeps it alive" [14]. Yet from 1965, conservation interventions were aimed at preserving the material remains while eradicating the spirit of the site. Surprisingly, the stream was diverted, and the inscriptions carved in stone were fixed with epoxy resin and gummed with silicone [14]. Hence, diverting the stream from the granite surface reduced the element to a carved stone that is allegedly credited with authenticity despite losing its intangible value.

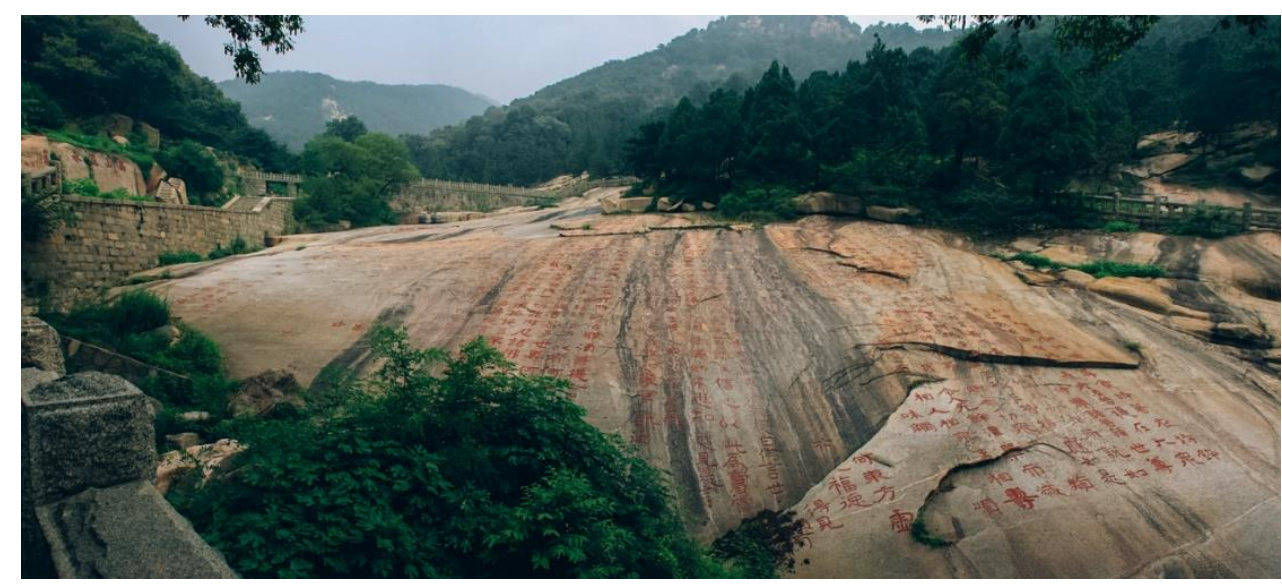

Figure 2 Panoramic view of Stone Sutra on the Sacred Mount Tai, China [25].

\subsubsection{The 1300 years old Cyclic Renewal of Shrines in Ise, Japan}

In east Asian countries, the intangible aspect of heritage within the process of conservation and restoration is highly regarded as a criterion of authenticity. In some countries, building rituals involving 
craftsmen acting in a priestly fashion is an inevitable aspect of authentic rebuilding. The cyclic renewal of many shrines in Japan, such as the Shrine of Ise (see Figure 3), is an example of reconstructions aimed at eternalizing the material and immaterial characters of a building.

The first renewal of the Shrine in Ise is documented to year 690 and has since undergone renewals at intervals of 20 years. Many documentations show that the form and layout of the shrine have only been subject to little modifications and a delicate harmony between aesthetic and technical principles [14]. Hence preserving a 1300-year-old ritual that was constantly replicating what is believed to be the original design. The cultural theorist Byung-Chul Han expresses how these countries have developed a technique which "overrides the difference between the original and the replica" [14]. To him, the continuous replication preserves the original through copies [14]. In fact, this shows how a ritual aspect of a cyclic renewal can better preserve the authentic building character rather than typical restoration acting on the existing fabric which may have undergone many alterations over the years. The process of reconstruction extends over eight years. Once dismantled, the wood of the Shrine is not wasted. Instead, they are salvaged and reinstated in the construction of different shrines in the country.

For the German architect Günter Nitschke, the process of renewal of shrines "resolve(s) the ultimate "disease" of time, both historical and natural: the yearning for sacred authority and sacred architecture to be extremely ancient, yet always pristinely fresh" [14].

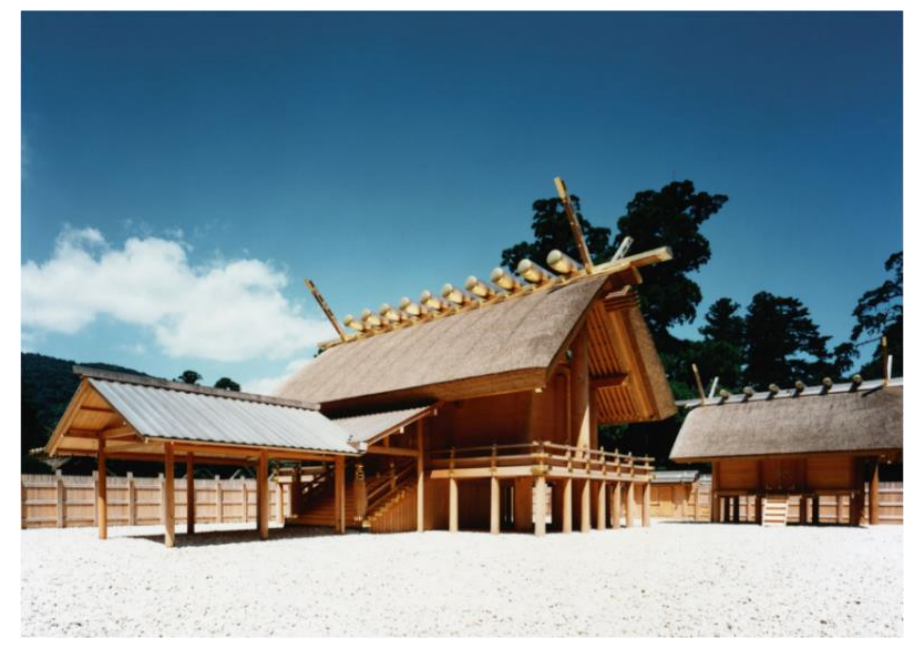

Figure 3 Sanctuary of the outer shrine in Ise, after its partial reconstruction (1993) [26]. 


\subsubsection{Craftsmanship practices in the conservation of the Mosque in Djenné, Mali}

Another example of intangible aspects of heritage related to authenticity are the traditions and rituals in some conservation approaches [27]. This concept can be seen on local masons' practices in Djenné in Mali (see Figure 4). The traditional skills were preserved by means of a guild which safeguarded the architectural heritage. The guild's practices and philosophy were not dictated through any text but were transmitted by craftsmen experience [27]. Consequently, authentic means of conservation is characterized by the performance-based traditional transmission of knowledge in which principles are set by the guild [27]. However, such practices may suffer a lack of documentation when they are only transmitted by experience, and thus lack of authentication.

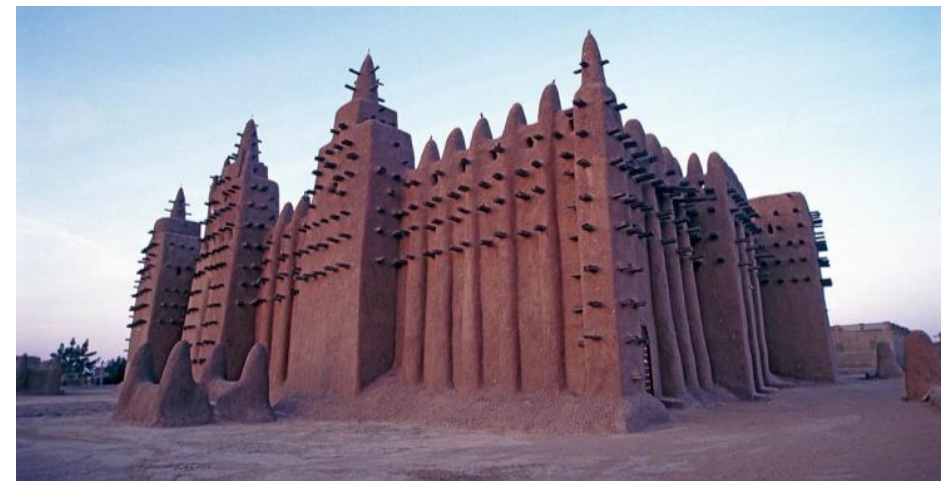

Figure 4 The Great Mosque of Djenné, Mali. The massive walls are erected by sun-dried mud bricks with mud mortar joints and plaster [28].

\subsection{Identity vs integrity}

Furthermore, Byung-Chul Han comments on the cyclical reconstruction of the shrine in Ise expressing that the copy is "more original than the original, because the older a building is, the more it distances itself from the original state" [14]. Hence, the aspects of identity through the embodied meanings versus integrity of the original fabric emerge as fundamental values. The American National Park Service Administrative Manual describes identity as "a composite quality connoting original workmanship, original location, and intangible elements of feeling and association" [29]. In 1996, the term integrity was revealed when the San Antonio Declaration intended "extending the proofs of authenticity to include a reflection of its true value, integrity, context, identity, use and function" [18]. In 2008, aspects such as spirit and meaning have been suggested by the Québec Declaration of the Preservation of the Spirit of Place [14]. 


\subsubsection{Rebuilding (1898-1908) and Reconstruction (1952-1953) - The Kinkaku-ji Temple in Kyoto, Japan}

The reconstruction of the fourteenth century Kinkaku-Ji temple is an example of a controversial identity (see Figure 5). The temple was considered a national treasure within the Law for the Preservation of Ancient Shrines and Temples of 1897 [14]. In 1908, a Japanese working procedure dismantled and laboriously reassembled the building. In 1950, the building caught fire and was subsequently reconstructed using the precise measurements of each timber component accomplished in 1908 [14]. With its new material, the World Heritage Conservation Guidelines implied that the replica of the temple be delisted and was considered inauthentic [14]. The author Douglas Adams (1952-2001), discussed the authenticity of the reconstruction and stressed feeling "mildly surprised at quite how well it had weathered the passage of time since it was first built in the fourteenth century" [30]. He later knew that the building was actually rebuilt twice in the $20^{\text {th }}$ century. He then thought that the current temple did not represent "the original building," although the tourism guide who was not familiar with conservation principles persisted that this was evermore "the same building." Adams continues that:

"the idea of the building, the intention of it, its design, are all immutable and are the essence of the building. The intention of the original builders is what survives. The wood of which the design is constructed decays and is replaced when necessary. To be overly concerned with the original materials, which are merely sentimental souvenirs of the past, is to fail to see the living building itself" [30].

This idea pinpoints the fact that original fabric is only one aspect of authenticity, which differs considerably between people and ethnicities.

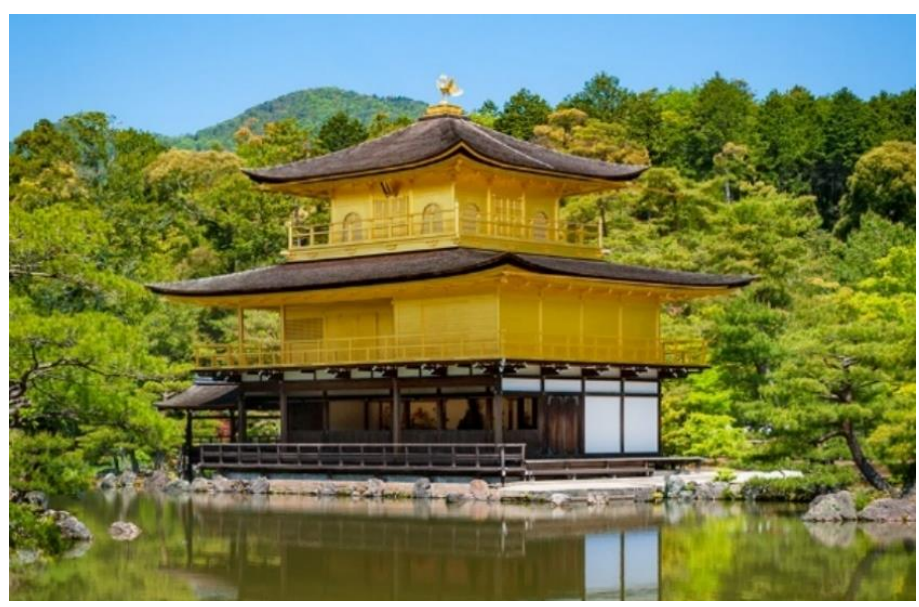

Figure 5 The Kinkaku-ji Temple in Kyoto, Japan [31]. 


\subsubsection{Restoration - The Kandinsky/Klee Meisterhaus in Dessau, Germany}

The Kandinsky/Klee Meisterhaus was built by Walter Gropius in Dessau in 1926 (see Figure 6). The house was deemed modern with its lucid and organic entity, resembling the human body. The defining character was the flat roof, which not only had functional and economic considerations but was also a demonstration of modernity. New construction techniques were also used as the construction involved stones composed of dross, sand, and cement. In addition, the balconies were a cantilevering extension of the reinforced concrete slab on two sides of the building [14]. After its recognition in the UNESCO World Heritage list in 1996, planning for the restoration of the house began in order to transform it into a public museum. The notion of authenticity emerged when the idea of "make a living and working conditions for the original inhabitants Kandinsky and Klee come alive" [14] was expressed while the attention was put into "bringing out the vision of the architect Walter Gropius in spite of the falsifying transformations" done to the building for more than 50 years [14].

Interestingly, the most controversial issue was preserving the cantilever slab of the balcony on the eastern façade, which was over the years supported by pillars to prevent it from collapsing. In fact, attempts to restore the slab to its primary state would have implied reconstructing the neighbouring ceiling slab and consequently wasting the original material [14]. The decision was made, as a cost-effective solution, to support the slab of the balcony with posts. Hence, preserving the original material was granted more priority over the integrity of the original character and thus compromising the cantilevering slabs that were essential to characterize modernity [14]. Indeed, the cantilevering slabs were intended to levitate in the air since the twentieth century was characterized by the ambition of defying gravity. Consequently, preserving the intentions of the modernist movement were compromised by the introduction of pillars [14]. Similarly perturbing was the distortion over daily use and maintenance of some details such as a stair tread (see Figure 7), which completely neglected the intentions of the Bauhaus.

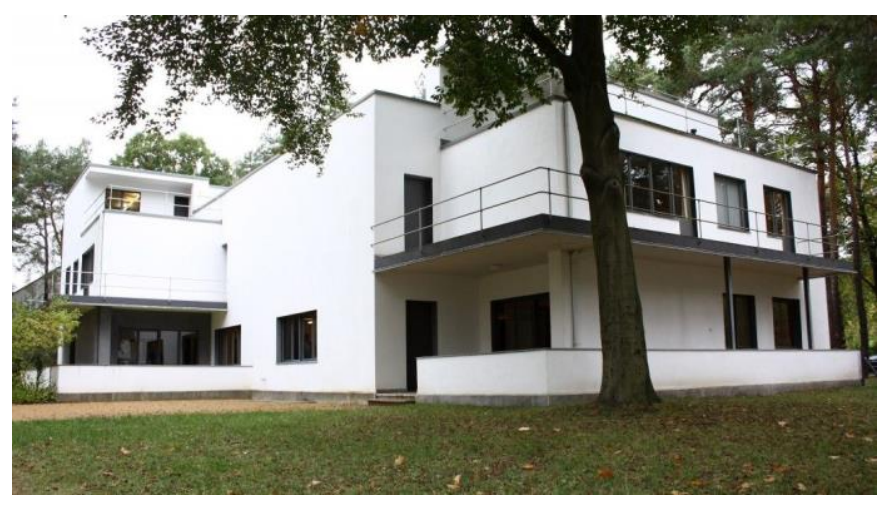

Figure 6 The Kandinsky/Klee Meisterhaus in Dessau, Germany, 1926 [32]. 


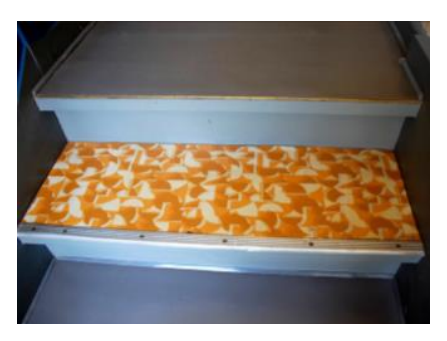

Figure 7 Staircase, Kandinsky/Klee Masters' house, Dessau, July 2010 [33].

\subsection{Patina or age value}

The patina is defined as "a surface appearance of something grown beautiful especially with age or use" [34]. In his book The modern Cult of Monuments: Its Character and Origin (1982), the Austrian art historian Alois Riegl (1858-1905) expresses that the main monument character is in its "age value" which is characterized by "scars, gaps, crevices, scratches, wrinkles" covering the fabric and embracing various values [14]. Riegl insists that there should not be any alteration to the natural mechanism of deterioration [14]. On the same line of thought, the art historian Georg Dehio (1901) affirms that "it is a psychologically deep-rooted longing" that "the old should look old, with all its experiences, such as wrinkles, cracks and wounds" [14].

\section{APPROACHES TO RECONSTRUCTION CONSIDERING AUTHENTICITY}

After assessing the various values that can be involved in a reconstruction project, it is necessary to evaluate the approaches that are considered among conservationists. Debates over reconstruction have been divided into two approaches: rebuilding in a contemporary style, inspiring a new beginning and erasing previous errors, or renewing in a authentic historicist style by replicating original characters and materials for reasons of identity and continuity [9]. A third alternative is the "Equivalent Reconstruction", which provides a practical compromise to restore the original scale, massing and detailing within a modern setting [9].

Contemporary Redesign implies a new design that is meant to replace what has been lost while potentially improving functionality, but if the new design is deemed to be unsuccessful, it can increase the feeling of loss [35]. Also, the contemporary style reconstruction was discussed in the Netherlands by opposing replication of vanished monuments versus adaptation to new use using contrasting architectural interventions [9]. The debates extended to assess that rebuilding heritage is meant for the public domain and that local communities preferences tend to differ from the professional standards of aesthetics and authenticity. Not to mention that the Modern Movement has its influence on these standards, involving 
the link between form and function as well as transparency. The glass-box additions to historic buildings are an example of this relationship, which can be seen on the Royal Ontario Museum in Canada (see Figure 8). Built in a neo-Romanesque style in 1914, the building was renovated by Daniel Libeskind in 2007 adding a glass, aluminum and steel addition which form is inspired by Art-Deco [36].

Authentic Reconstruction done in accordance with the Burra and Riga Charters requires sufficient historical evidence of the previous design in order to be able to return to an earlier state, preventing falsification of the overall context, preserving the remaining significant historic fabric and proceeding only after an open consultation among relevant authorities and parties of concern. This option still implies losing the patina of age but provides a learning experience for craftsmen on traditional materials and construction techniques [35].

Equivalent Reconstruction is considered when there is insufficient historical evidence of the previous state and adopting the idea of constructing something reminiscent, but simpler using contemporary techniques. The significance of character is conserved in its overall effect, although some details are lost. This option is a pragmatic solution, but it also creates disappointment when the building does not resemble the previous one, and the design is not a new one either [35].

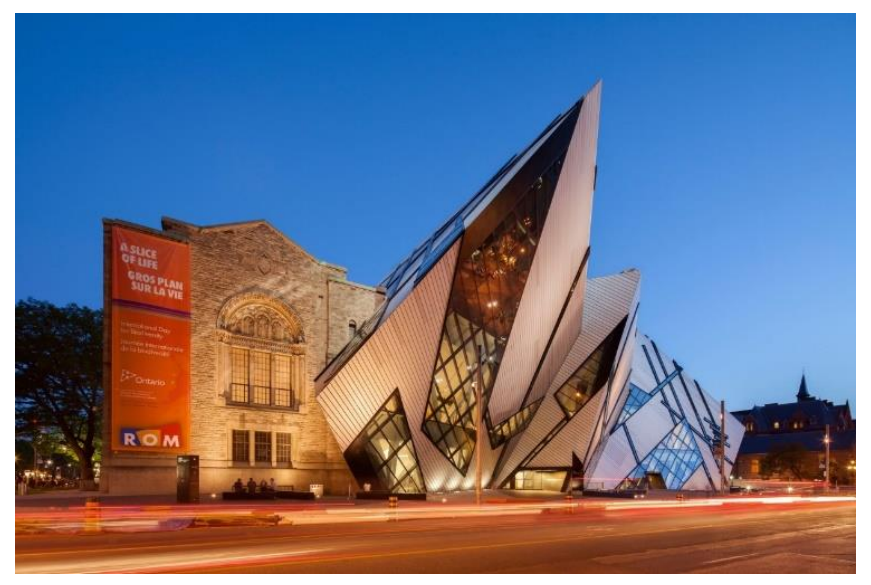

Figure 8 Royal Ontario Museum in Toronto, Canada [36].

In the current study, the approach of contrasting architectural interventions that tend to rebuild a portion of the building using a modern style is not considered reconstruction. This study considers "authentic reconstruction" which is also referred to as "historicist reconstruction". Nonetheless, it is acknowledgeable that this contemporary approach aims at preserving the historic character of a monument by distinguishing it from its surroundings. 


\subsection{Value-based approach}

When reconstructing historical monuments, it is essential to decide which part of the building should be reinstated. The value-based approach is a way to analyze and predict the main characters to be preserved within a rigorous method. Canada's historic places guidelines state that the first step in understanding restoration is to "identify and describe the character-defining elements that are important in defining the overall heritage value of the historic place" [7]. In the same guideline standard, the most important character-defining elements are expressed in the Statement of Significance (SOS), which is used by builders during the restoration process [7]. Hence, if the value was in the patina or ageing of materials, then this character cannot be reconstructed. Also, if the value was its space function and use, a reconstruction may be able to restore that character. If the value was in its aesthetics, a thorough analysis of the lost characters enables to recreate that character [35].

\subsubsection{Partial Reconstruction of York Minster}

In England, an eleventh-century cathedral known as York Minster saw the south portion of its roof destroyed by fire in 1984 (see Figure 9). Builders debated the design of the new roof and vault as well as the material of the elements. The decision made by the estate manager for the cathedral was to replicate the original design with minor differences to preserve the architectural character of the Minster (see Figure 10). Yet the sheathings which primarily capped the web of the vault (Figure 11) were replaced by a metal mesh sandwiched between fire-retardant plasterboards in order to prevent flames spread [9]. From the above-stated approaches, this example used the authentic (partial) reconstruction approach.

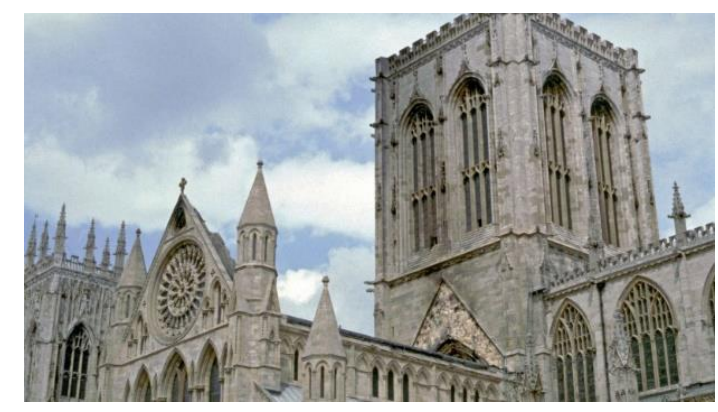

Figure 9 York Minster south vault destroyed by a fire in 1984 [37]. 


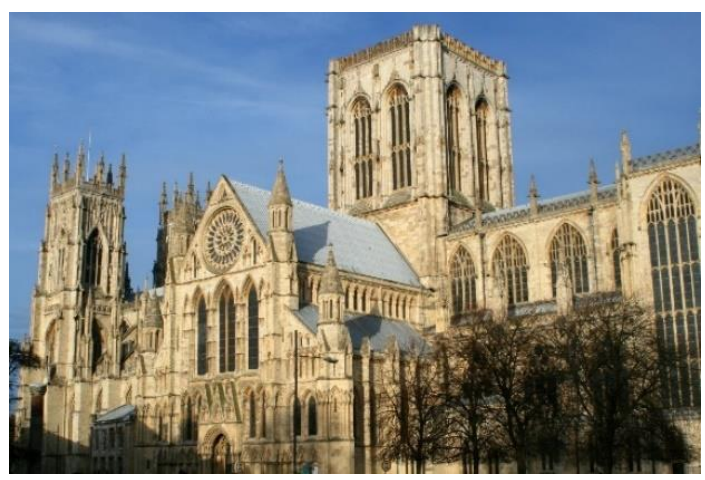

Figure 10 York Minster cathedral after restoration of the roof [38].

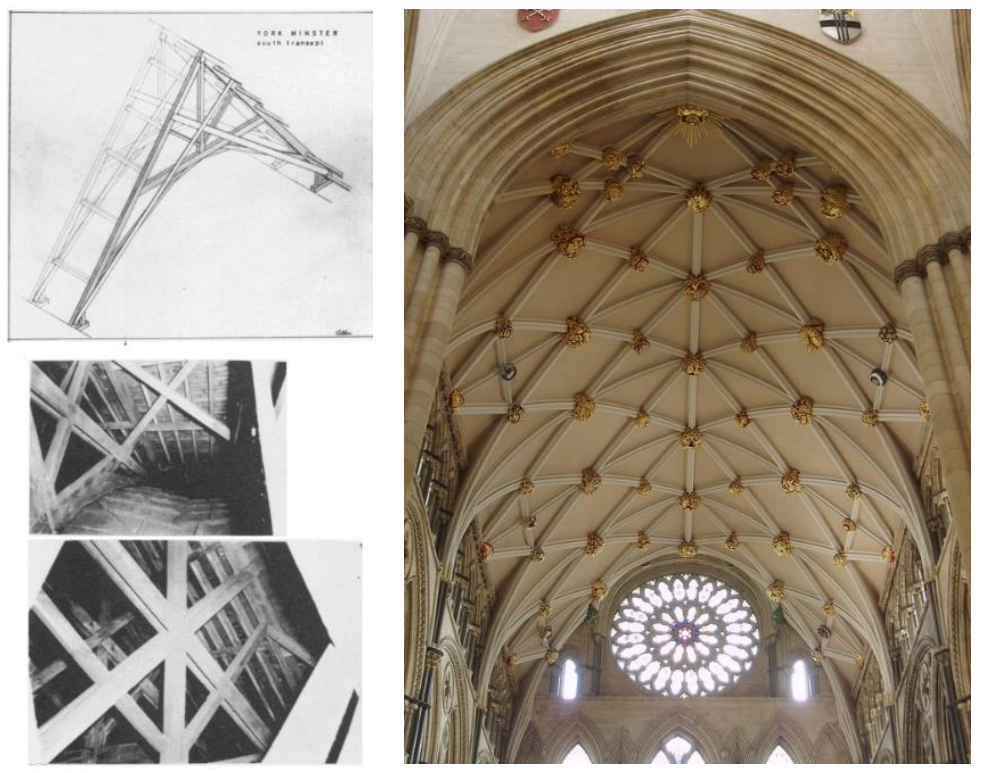

Figure 11 South Transept Vault, York Minster, as seen in 1965 (left) [39] and rebuilt after the fire in 1984 (right) [40].

\subsubsection{Partial Reconstruction of Uppark House and Garden}

Uppark House and Garden, built in 1690, is part of the National Trust since 1954 (see Figure 12)[41]. The building caught fire in 1989 during a roof restoration. The fire destroyed the roof and the ceilings but did not completely eliminate the decorative woodwork and plasterwork. A fire investigation was followed by a management plan to assess remains. The plan labelled each room into grid squares to locate each specific element. Different groups of interest were divided on whether to adopt an authentic reconstruction approach or rebuilding in a modern style, or a mixture of the two [42]. The Society for the Protection of Ancient Buildings (SPAB) stressed that "no attempt should be made to create a lifeless replica of the eighteenth century rooms," insisting that the roof should be reconstructed along with the interior spaces to be exhibited as a museum for the National Trust [9]. Finally, the National Trust decided to adopt a framework based on an authentic reconstruction approach. Although an attempt was made to avoid 
reconstruction and opt for rehabilitation, the pressure of affordability and competitive tenders meant that absolute repair work had to be compromised to be eligible for insurance cover [9]. In sum, the reconstruction was meant to reinstate the building at its condition before the fire (see Figure 13). Also, the process included thorough photographic and photogrammetric records as well as computer-aided design (CAD), which made the work more accurate within a shorter time slot [42]. In addition, the original material was collected and put into 3,860 dustbins labelled with the grid references, which permitted reinstatement and relocation of the original elements at the right place (see Figure 14) [9].

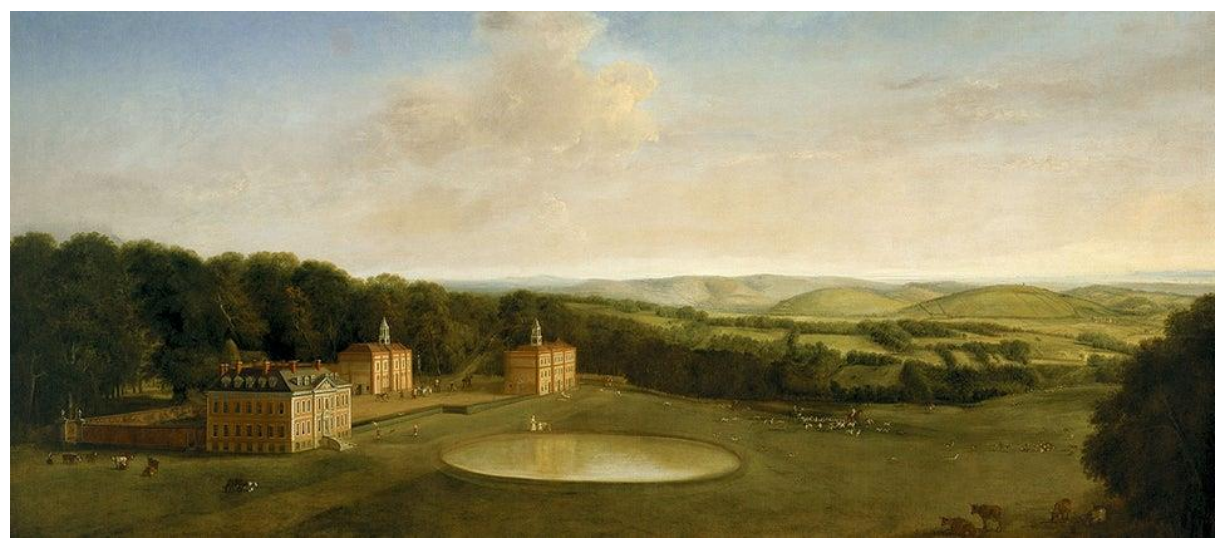

Figure 12 View of Uppark by Pieter Tillemans, circa 1728-30 [41].

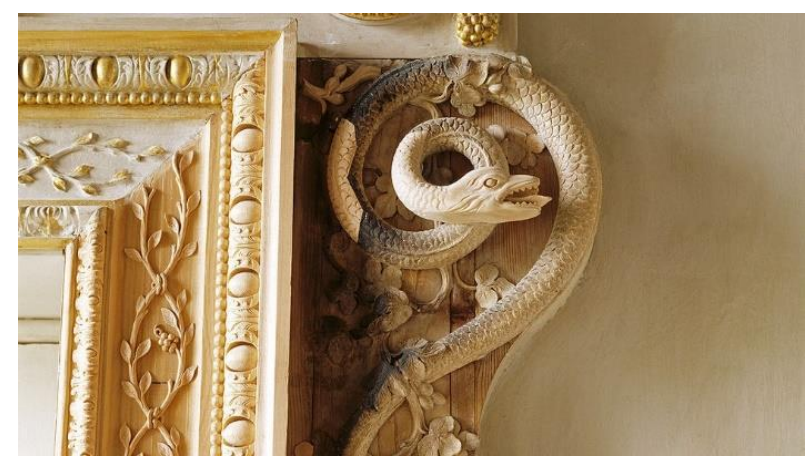

Figure 13 At Uppark, some burnt details were left unpainted to show where the old and new meet [43].

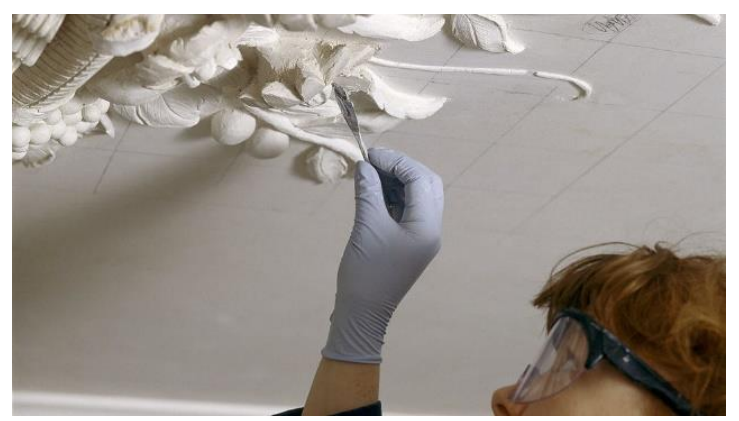

Figure 14 A plasterer working on the reinstatement of the ceiling of the Red Drawing Room at Uppark [43]. 


\subsection{Function, programme and adaptation}

Reconstruction in urban areas is often subject to adaptation and change in response to commercial and economic demands as well as the evolution of people's relationship to their environment and to architectural trends [9]. Architects then face new challenges in adapting buildings of architectural significance to new uses without compromising their value in the built environment. The preferred approach is to preserve the historical, social or economic value while enhancing the environment and the quality of life [9].

An example of adaptive reconstruction is the Battersea Arts Centre in London, which was damaged by fire in 2015. The Grand Hall's upper parts were destroyed by fire as well as the lower level fabric finishes [9]. Other elements were damaged by water following the firefighting action. The external envelope was rebuilt to match the original using 10,000 salvaged original bricks (see Figure 15). The surviving elements of the Grand Hall were preserved. In order to recover for the lost material, a new timber mesh ceiling and a demountable gallery were added at a high level (see Figure 16). Other elements were also reinstated to return to their original state [9]. The resulting building is an example of authentic reconstruction of the exterior envelope and equivalent reconstruction mixed with contemporary design (Figure 17) to the Grand Hall made improvements to allow for a wider range of events in the centre [9]. Hence, replacing lost elements with contemporary material rather than replicating them was determined by the needs of functionality embedded in the twenty-first-century activities of the local community.

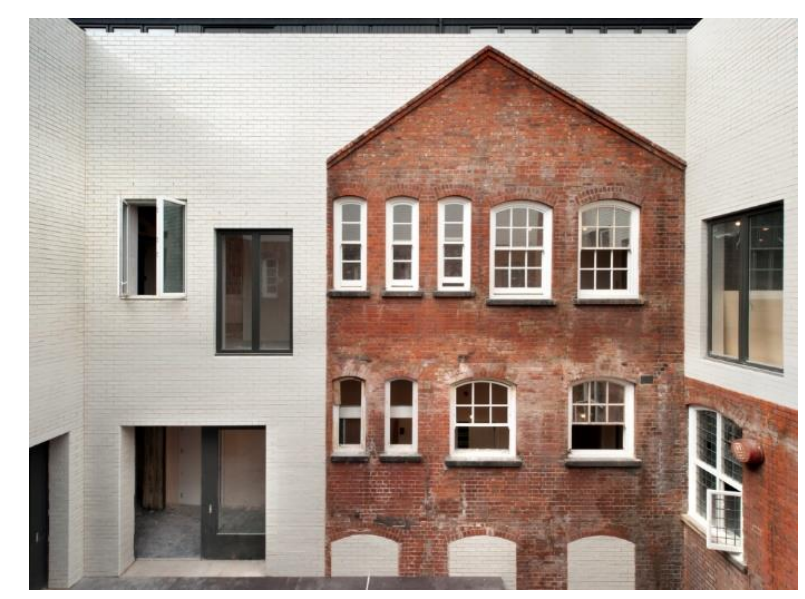

Figure 15 Reconstructed envelope on the Battersea Arts Centre using original salvaged bricks [44]. 


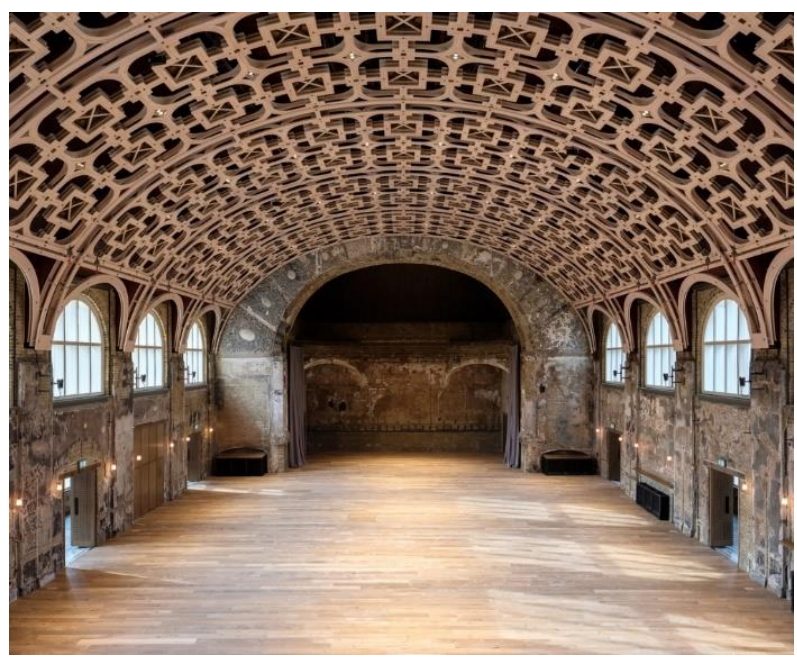

Figure 16 New timber lattice ceiling at the Battersea Arts Centre [45].

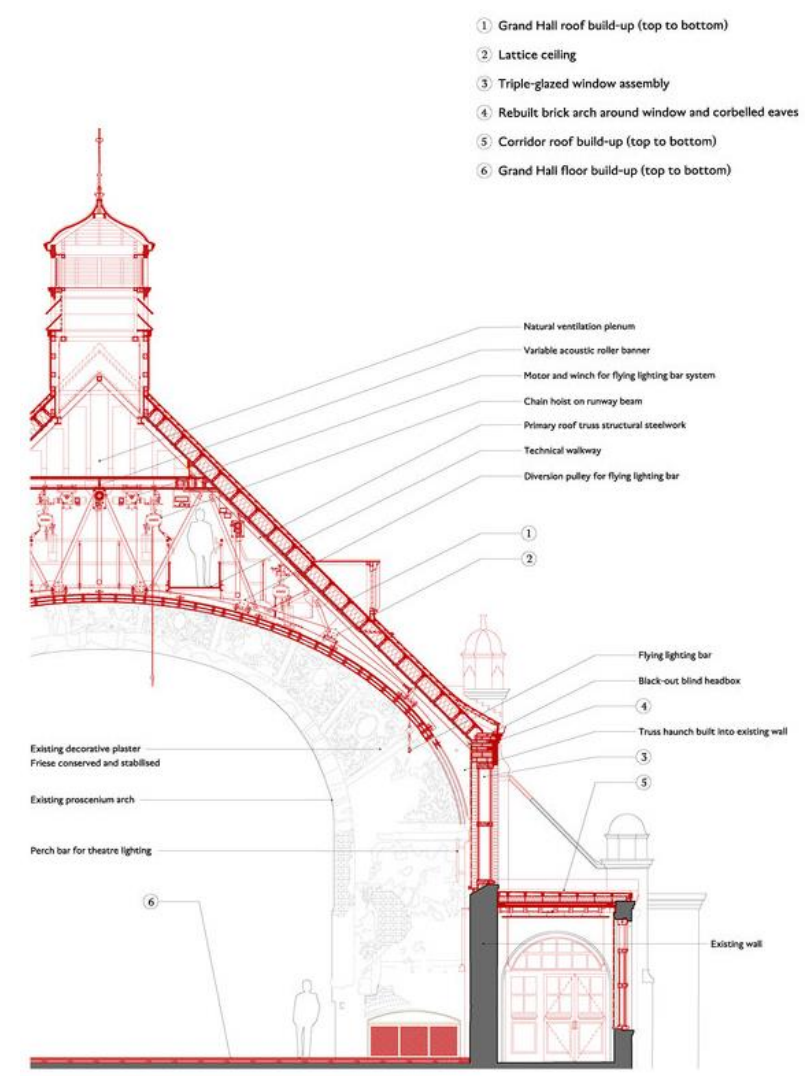

Figure 17 A detail section of the Grand Hall in Battersea Arts Centre [44].

Moreover, the function of a building is sometimes valued as a heritage character. The Stare Miasto was supposed to be reconstructed with dwellings with some services and activities to instore a new beginning in the region [9]. The buildings facing the main market were given earlier service functions such as restaurants and shops (see Figure 18). Hence, the goal was to preserve the layout plan, which dated from 
the eighteenth century [9]. However, many monumental entrance halls dating from the Middle Ages and the Renaissance were altered over time. It was difficult to adopt new regulations concerning living conditions as well as kitchen and sanitary installations that had to be implemented in every apartment. The rooms' dispositions were to be maintained if the authentic fragments of the building were deemed of great architectural value. Also, the building would not be converted to larger apartments if the transformation altered the character. Instead, they would host cultural institutions. The façades were to be kept intact as well as the roofscape. The roofscape was conserved by keeping the old chimneys for ventilation with central heating systems installed under the floors [9].
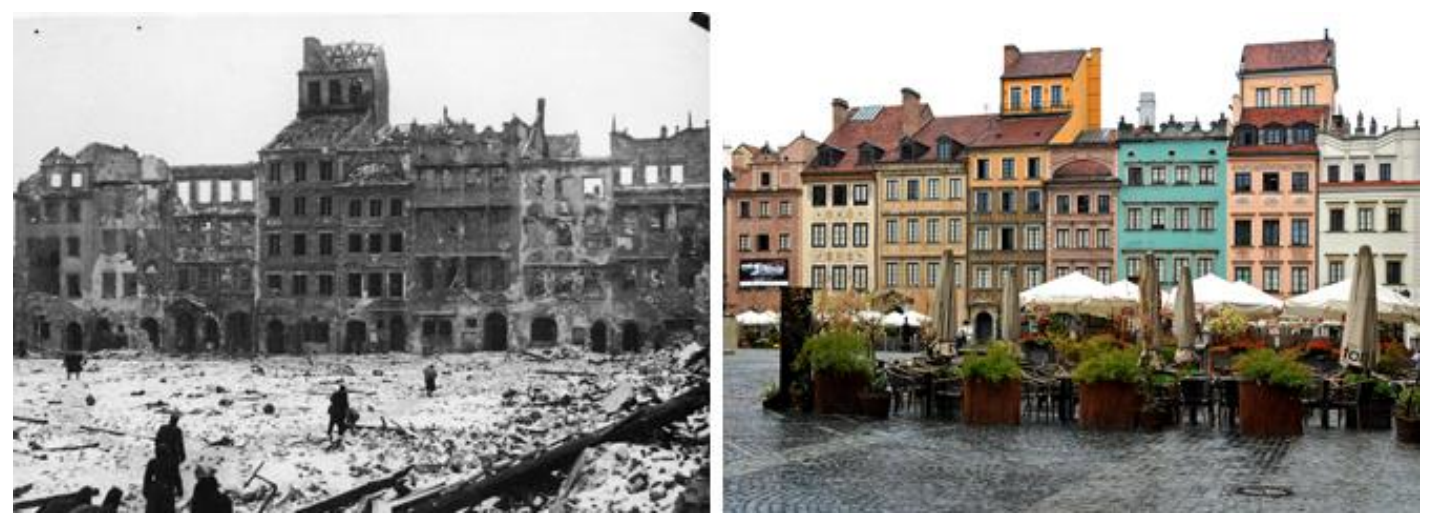

Figure 18 The Marketplace of the Old Town (Stare Miasto) of Warsaw following the WWII attacks (left), and following reconstruction (right) [46].

\section{PROCEDURAL CONSIDERATIONS}

The fourth section of the first part of this study aims at pinpointing various procedural considerations to be observed during a reconstruction project. These considerations are summarized from Authentic Reconstruction: Authenticity, Architecture and the Built Heritage, a book edited by John Bold, Peter Larkham, Robert Pickard.

\subsection{Documentation}

Although the Venice Charter had disapproved reconstruction, it allowed restoration "based on respect for original material and authentic documents" [3]. The variety of resources available presenting historically reliable reconstruction are photographs, old drawings, paintings or architectural detailing [9]. Documentation often reinstates only portions of the building character and needs interpretation of the materials and forms as well as determination of the values conveyed by the architectural traits [9]. 
As the China Principles require, explanatory signage should display relevant documentation showing detailed assessment of the reconstruction process and distinguishing restored and remaining original elements [8]. New materials should be signposted and recorded in detail [6].

\subsection{Technical provisions}

The technical requirements for any construction have to adapt to the change in technologies, building materials and building methods. Today's use of unplasticized polyvinyl chloride (upvc) in replacement of timber for windows and doors is a good example. Another challenge is the loss of skills in traditional and vernacular construction and repair techniques [9]. The assessment of technical requirements considers the survival of fabric, the presence of appropriate documentation, the availability of suitable materials and expertise, as well as the potential workforce and funding.

\subsection{Engaging community}

The starting point for authentic evidence is scholarly documentation unless there are overriding social imperatives. The meanings embodied in monuments are statements of a nation's identity meaning that society should be engaged in heritage policies [9]. The conditions of a place, its history, its evolution over time and its past and present importance are often experienced by the local community [7]. Architects and planners need to work hand in hand alongside community groups by gatherings information and discussing design options. At the same time, all contributors should promote public understanding of the heritage value and respect towards its history as well as its evolution and the social and environmental factors that led to its reconstruction [9].

\subsection{Moving Forward - Tools and Guidelines}

\subsubsection{Digital technologies to improve the conservation process}

The three-dimensional (3D) technology has developed and augmented the traditional recording techniques for historic buildings such as hand measurement and photogrammetry. It has improved documentation and analysis of buildings and provided guidance for works within architectural reconstruction. A digital 3D model with laser scanning and photogrammetry enables surface analysis as well as a recreation of aesthetic forms and characters. Also, building information modelling (BIM) allows energy performance analysis as well as assessing the constructability of the architectural components within a complex or non-familiar assembly. Other mapping tools are now being developed, such as multiple light imaging, through Reflectance Transformation Imaging (RTI) techniques with Polynomial 
Texture Mapping (PTM) [9]. This technique is used to create texture maps of components and uses multiple digital photographic images. Collecting and developing heritage material digital archives is now possible. A good example is the Million Image Database Project by the Institute of Digital Archaeology (IDA), which provides a library of 3D imagery of endangered sites in the conflict areas of the Middle East, North Africa and Asia (see Figure 19). Hence, the use of BIM for heritage buildings will enhance the decision-making process [9]. Also, smart technologies such as virtual reality (VR) headsets enable better visualization of the reconstruction design. The IDA has also pushed forward the use of 3D replication by investigating proprietary cement, sandstone or marble-based 3D printing and carving techniques [9]. A good example of 3D printing is the recreation of the 2,000-year-old Arch of Triumph in the city of Palmyra, Syria, which was demolished by ISIS in 2015. In 2016, the replica was constructed in Trafalgar Square, London, as well as in Manhattan's City Hall Park, New York. However, this technology will also need clear guidelines on approaches since the recreation may exclude some historical records, as seen in the remodelling of the Palmyra arch, where the digital model was edited to exclude records of bullet damage on the stones [9].

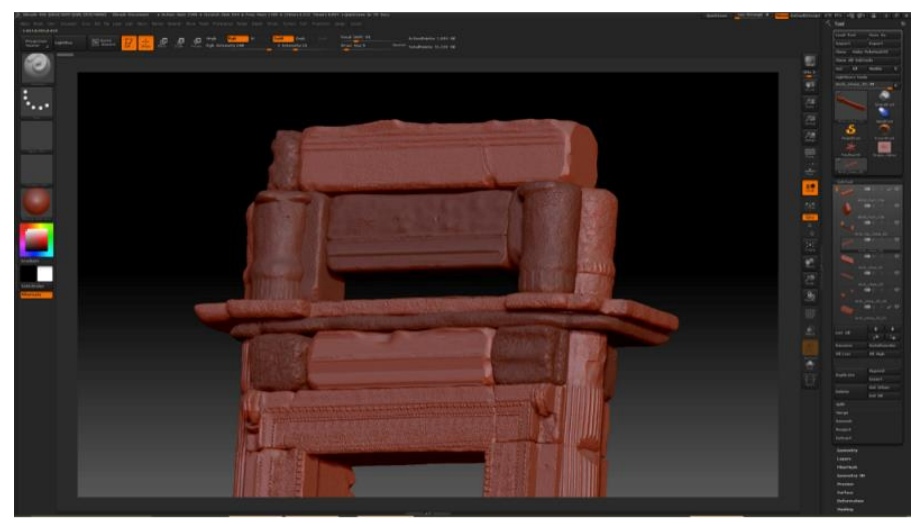

Figure 19 A 3D computer model can image surface detail and texture with stunning accuracy, an important tool in modern archaeology [47].

\subsubsection{Guidelines Issues}

Among issues in the reconstruction process is the lack of adequate planning control and protective legislation. Buildings of heritage significance are often exploited for commercial purposes of left to deteriorate without investment in maintenance and repair. Yew-Thong Leong, professor at the Department of Architectural Science at Ryerson University, expresses that guidelines for heritage conservation are very general and thus allowing for a wide variety of options, which makes it difficult for conservationists to rely on them and ensure authenticity. He also noted that in European countries, the view of the architect "carries more authority" which can be beneficial in some ways. However, he raises 
that European conservationists often allow for layers of technology to be imposed on a building, which can be assessed in some cathedrals that exhibit characters from different periods in time. The issue resides in the absence of ownership and responsibility in situations where the benefits of reconstruction are not perfectly defined and understood. Moreover, it is important to determine who is concerned with a monument and who has the right to assess and interpret its heritage values [8]. In fact, many demolished buildings in the Old Town of Tbilisi, Georgia, have been replaced with either poor imitations or inappropriate modern designs [9]. Leong also stresses that preservation work relies many times on interpretation where decision-makers can provide an argument using simple precedents, where no ideal solutions can be found. The lack of control and political interference can result in the loss or change in the character of urban centres.

Moreover, another issue is the terminology which is offered as a rudimentary guide rather than a clear set of definitions. Also, the definitions are in English only and do not express the variety of interpretations that could derive from other languages and cultures. For example, the notion of "looking the same" may imply a pragmatic, optimistic recovery rather than a perfect replica.

Consideration of authenticity will necessarily lay opinions and complicate decisions making as no one can truly validate any judgement of success or failure in achieving authentic reconstruction. The question raised is to know whether the concept is represented by original or replacement materials assembled in a traditional form or settled in the feelings and values embodied in the elements [9].

\section{PARTIAL CONCLUSION - PART 1}

There are different ways of reconstructing heritage building that has been lost through man-made or natural disasters, but the answer is surely not simple or binary. In addition, today's social interaction implies feelings and outraged moral judgments in an interconnected digital world with instant responses. The case studies have shown the need for individual approaches considering national and local requirements, which are affected by many factors. These factors can sometimes conflict with each other at some level. The factors include the need to revive identity and memory, the need to upgrade the performance of a building in relation to an upgrade in living conditions, the need to represent political or ideological statements, the need to represent contemporary or historicist paradigms, the need to reinstate function, or the need to attract tourism investment [9].

Reconstruction is most likely to divide both specialists and lay opinion on how a place used to be or how it should look like. Moreover, in defining authenticity, the nature of arguments involving European, North 
American or Asian approaches have shown the existence of tensions between conservationist philosophies. However, when looking more closely through examples, it is remarkable how categories of value that appear to be segregated are not that much mutually exclusive. The Nara Document on Authenticity were aimed at applying "the test of authenticity in ways which accord full respect to the social and cultural values of all societies" [2]. However, judgements about values cannot be absolute nor universal, meaning that it is not possible to determine a fixed criterion for authenticity since heritage value is described within its specific cultural context. The cultural context is expressed in appearance and fabric, function, rituals and craftsmanship, location and surrounding, feeling and spirit as well as other factors [2].

Consequently, there are no generic approaches or straight forward guidelines applicable to the reconstruction of heritage buildings [9]. Whether reconstructing a building in a contemporary or historicist style with modified detailing, the reconstruction will always need site-specific considerations. In fact, it is not desirable to adopt a generic guideline for post-disaster reconstruction since every case is specific and needs an advisory framework that is agreed between concerned parties.

Another question arises about the decision-making process in the reconstruction of buildings with historic significance. Are the decisions to be made based on political and economic interests, made by an authorized group of historicist architecture experts or through local community collaboration? In some cases of East Asia, the process is also influenced by culture involving craftsmanship and intangible aspects of authenticity. Perhaps a flexible, creative and collaborative approach is needed between architects, planners, heritage professionals, and other concerned groups who have been involved in reviving the targeted historic place would help in attaining practical solutions away from fixed academic methodologies. 


\section{PART 2 - DESIGNING HERITAGE BUILDING COMPONENTS WHILE COMPLYING WITH CURRENT CODES AND REGULATIONS}

Today, a challenging aspect of the process of heritage building reconstruction is preserving the original heritage characters while meeting current codes and standards. For example, meeting today's life-safety requirements may imply to incorporate protection systems such as a sprinkler system which would be intrusive to the interior look of a space and thus changing the character of the building. Another example in today's construction requirements is the energy performance of a building, which impacts the design of the building envelope and the HVAC systems. Architecture is well defined by the building envelope, and modifications to it would necessarily cause challenges to the heritage character preservation. The first part of this study has shown the principles governing a reconstruction project from a qualitative perspective. These principles help understanding the challenges of what reconstruct and why, which is essentially useful at an early stage of the redesign process. The second part of this study will assess the technical challenges related an actual code-compliant redesign of a demolished building. This part is divided into two sections: outlining a typical process of heritage building redesign within the Building Code and applying the process to the partial redesign of a demolished building.

The application of the process presents the heritage aspects of a building that need to be considered before initiating the design of components. Then, the study applies a code compliance path and its related impacts and challenges on the heritage character of a specific building element. The studied building is the Banff Pavilion in Alberta, which was designed by esteemed architect Frank Lloyd Wright (FLW) in 1911, constructed in 1914 and demolished in 1938 after being hit by flooding and frost [48].

\section{OUTLINING THE PROCESS OF REDESIGN WITHIN THE BUILDING CODE}

As mentioned in the first section, the Standards and Guidelines for the Conservation of Historic Places in Canada establishes practical guidelines and principles for anyone considering the conservation of historic places [7]. This section outlines the process of integrating the value aspect of a heritage building to a regulatory framework in order to evaluate the potential impacts on its key heritage characteristics.

\subsection{Understanding the heritage value using a Statement of Significance}

The Canadian Register of Historic Places (CRHP) lists all historical places that are formally identified for their heritage value by their respective authorities. The Statement of Significance (SOS) for the historic place is an important document that sets adequate "goals, standards and techniques" of conservation [7]. 
The SOS describes the heritage place and its importance carried out by a value-based approach. The goal of the first step is to pinpoint all the essential characteristics that grant the building its heritage value. It will be useful for decision-making when facing specific technical challenges.

\subsubsection{Purpose of a Statement of Significance}

The Statement of Significance (SOS) is a brief document describing the heritage value of a building that ensures they are conveyed in a constructive manner to be compatible with different jurisdictions [7]. The SOS recognizes essential aspects of a building that shall be conserved in order to keep its heritage value. It is formulated in three parts:

- The Description of Historic Place which describes the physical features such as appearance, location and physical limits.

- The Heritage Value describes the reasons that led to assert the importance of the building to its community, territory or nation.

- The Character-defining Elements (CDEs) identifies the essential characteristics that shall be conserved [7].

The SOS is submitted to the Canadian Register of Historic Places (CRHP) and does not encounter any existing regulations but may be used along with them [7].

\subsection{Character-Defining Elements and their Implications on the Building Code Requirements}

The Building Code requirements are aimed at ensuring a minimum standard of life safety. Sometimes, the requirements interfere with the intent of the design and restrict its potential to meet the architectural design purpose. In these cases, the code provides alternative solution paths based on the functional statement of each section. Some requirements are often translated into performance factors that serve as a design objective to be met by an alternative solution.

This section analyzes the character-defining elements and their implication on the Building Code requirements. It aims at narrowing down to a specific framework within the Building Code. At this stage of the redesign, it is essential to determine, based on the Statement of Significance, the parts of the Building Code which are most concerned with the Character-Defining Elements (CDEs). The idea is to anticipate the critical Code requirements that could potentially alter the CDEs. These requirements will 
be the core of the analysis along with their respective CDEs. It is also necessary to anticipate the type of analysis that is needed in order to evaluate whether or not the CDEs will be affected.

In the case where the character can be significantly affected, the goal is to determine potential codebased alternative compliance paths in order to preserve the character. Realistically, the study cannot present every single compliance path that a professional designer can take within each type of component. Instead, efforts were made to establish a common path that one can take for a specific building element.

\subsection{Determining the Constructional Approach}

In order to determine how to comply with a specific Code section, it is necessary to assess the design options which present various construction possibilities. For example, there are different construction configurations for wood-framed wall assemblies, it is necessary to choose which are the most suitable for the studied building based on the previously anticipated impact on the CDEs. At this stage, the designer must identify the specific building element that has the potential to alter the CDEs. This element is the variable of interest for the rest of the evaluation.

\subsection{Analyzing Different Scenarios}

The final step is to assess the impacts of code compliant design on the CDEs and to judge on the acceptability of the design from a heritage perspective. In cases where the design is deemed too intrusive to the CDEs, it is imperative to discuss alternative Code compliance paths that provide more flexibility from a design point of view.

\section{APPLYING THE PROCESS TO THE PARTIAL REDESIGN OF THE BANFF PAVILION}

As for the studied building, a Statement of Significance of Frank Lloyd Wright's Banff Pavilion was established in 2018 as part of an assignment under the Sustainability of Existing and Heritage Buildings course at Ryerson University, Toronto. The document is used as a reference for the following sections.

\subsection{Understanding the heritage value using a Statement of Significance}

\subsubsection{Description of Historic Place}

\subsubsection{Frank Lloyd Wright's Banff Pavilion (Banff, Alberta)}

The Banff Pavilion is a prairie-style picnic shelter. It is the only public building in Canada to be designed by Frank Lloyd Wright (FLW). It is located in Banff Park in Alberta. In 1911, Wright and his only Canadian 
student Francis Conroy Sullivan designed on the banks of the Bow River [48]. The building was completed in 1914, and in 1939, many years of welcoming tourists and attracting large groups of people, the building was demolished, regardless of the community's objection, after it was damaged by flooding and decay [48]. Since the 1980s, many attempts were made to reconstruct the building. The documentary filmmaker Michael Miner, who committed a large portion of his career to the contribution of FLW, recently led a group of volunteers in the revival advancement [48]. As can be seen in Figure 20, original plans of the Banff Pavilion are made available by Public Archives Canada.

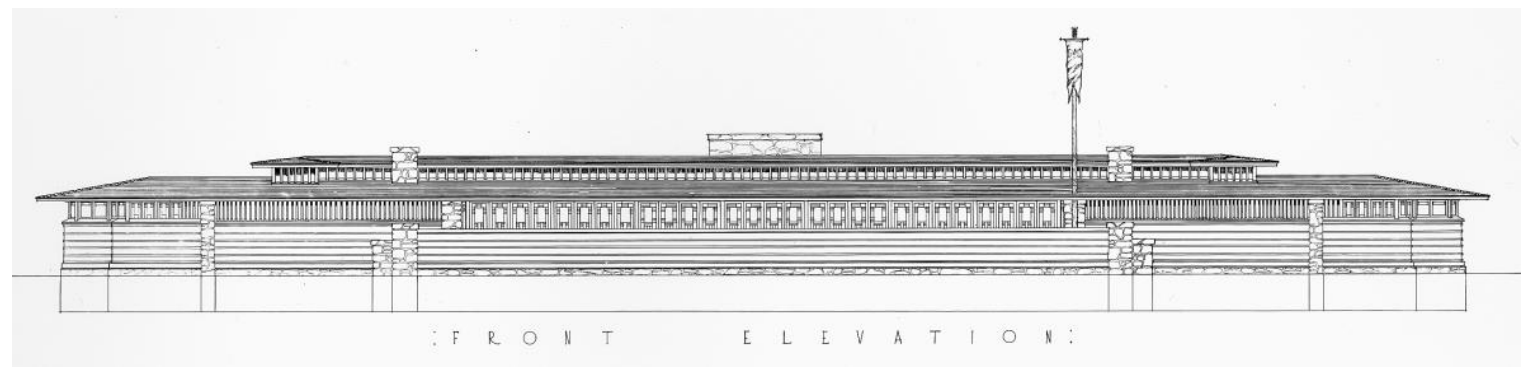

Figure 20 Original front elevation drawing of the Banff Pavilion [49].

\subsubsection{River Forest Tennis Club (Chicago, Illinois)}

At the time of this study, a group of researchers from Ryerson University in Toronto are involved in the reconstruction of the Banff Pavilion (see Figure 21). The group mandated the author of this study to examine the River Forest Tennis Club in Chicago, Illinois, a building designed and constructed by FLW in the 1900s and has a similar design to the Banff Pavilion (see Figure 32). The goal of this visit was to assess typical FLW's Character-Defining Elements within the building in order to produce a Statement of Significance (SOS). During the visit, many characters were identified as essential to FLW prairie style buildings, which later helped pinpointing essential Banff Pavilion character-defining elements to be preserved.

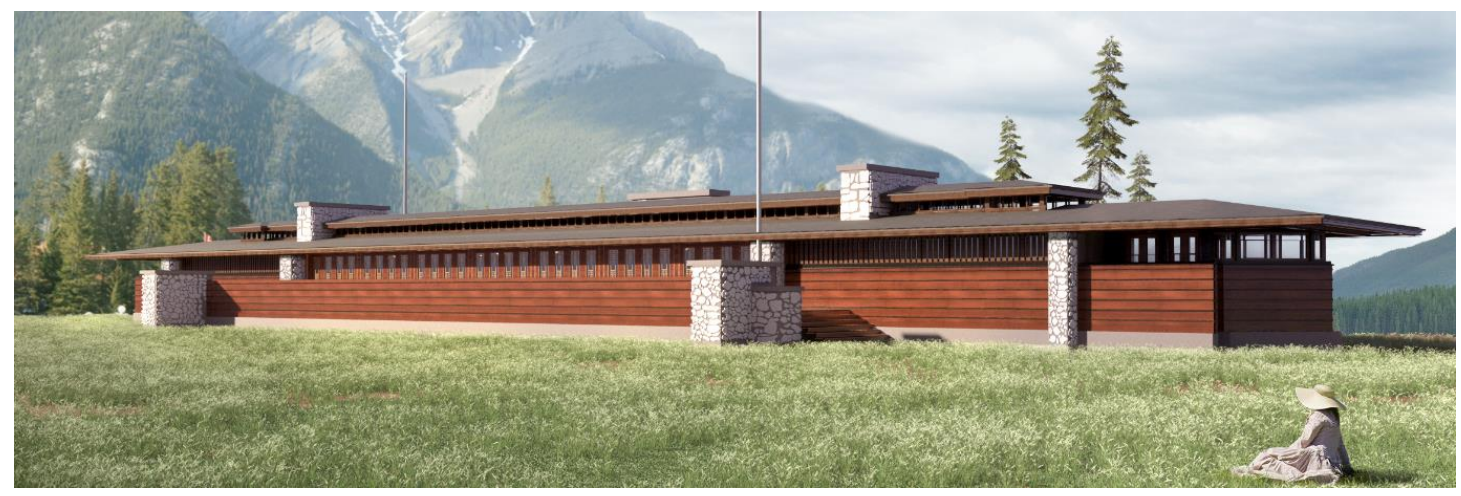

Figure 21 Banff Pavilion architectural modelling by a team of students at Ryerson University led by Pr. Yew-Thong Leong [1]. 


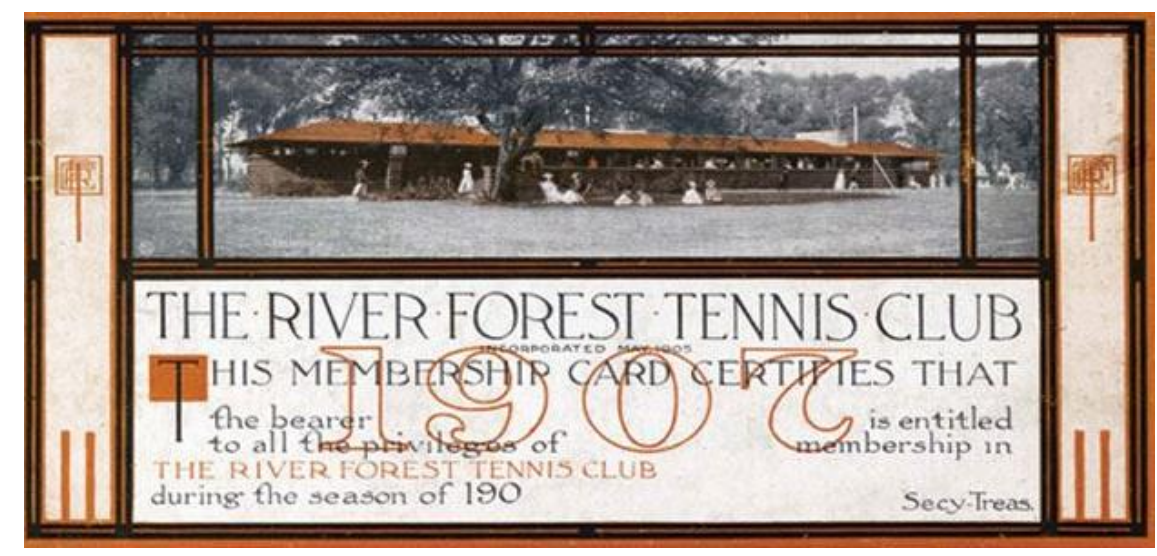

Figure 22 Frank Lloyd Wright's River Forest Tennis Club (RFTC) as seen in 1906 [50]. Strong similarities are observed between the RFTC and the Banff Pavilion.

\subsubsection{Heritage Value}

The essential heritage value of the Banff Pavilion remains in its aesthetics and the imprints of the esteemed architect Frank Lloyd Wright. In the 1900s, FLW was a leading figure of the North American modern architecture movement. The Banff Pavilion is one of two only buildings and the only public building built in Canada. Its historical significance goes back to the 1900 s where the Banff National Park turned to be well known and popular and accessible to a wide variety of people and served hundreds of users over the years which contributes to its cultural significance and its potential in the progress of the community [51]. Michael Miner views it as a "genuine work of art" [48].

What essentially defines its heritage value are the architectural expressions that are viewed as typical to FLW prairie style work. That is to say, the relevant values are reflected in all of the elements that can be designated as FLW style.

The design integrates many elements associated with the landscape of Banff Park and the development of Canada's cultural places. The building uses local materials from Alberta, such as Cedar wood and local stones, which emphasize its identity. Arthur Allen, an architect who was lived in Banff, expresses that he "loves the natural quality of Wright's work" [51].

\subsubsection{Character-Defining Elements}

The Character Defining-Elements (CDE) has been previously determined in a student project done at the Ryerson's Department of Architectural Science. It is assumed that all hidden elements within the construction assemblies are not character-defining, which implies that one must preserve the function and the appearance of certain elements without necessarily using the same construction technique. 
The essential elements that characterize the heritage character of the Banff Pavilion include the following:

\subsubsection{Use as a public facility}

The function of the building must not be changed to other than its original intent.

\subsubsection{Cultural heritage and an essential work of art}

The aesthetic aspects typical to the architect's work of art must not be altered, neglected or incorporate added aspects that do not belong to the architect's work.

\subsubsection{Site location and Building Orientation}

The building location as a part of the Banff Park planning with its proximity to the Bow River and to the bridge that crosses the river, which was also present in 1914. The location and the building orientation also play in the natural integration of the building in an FLW prairie style design. The row of art glass windows and the outside terrace look eastern than south towards Sulphur Mountain.

\subsubsection{Building Shape and Elevation}

The building shape has a broad width to height ratio, which emphasizes its horizontality. Its flattened appearance is characterized by the main elements such as the perimeter walls, the roofing, the chimneys, the terraces, and the glazing layout. In 1910, Wright carefully expressed that the "horizontal line is the line of domesticity." To him, prairie residences should be "married to the ground" [52]. Compromising unnecessary height in order to be closer to the earth, grants the building a more intimate relationship with nature [52].

\subsubsection{Building Layout and Spaces}

Figure 23 shows how the interior space is an open plan, and interior walls are fashioned as screens to prevent any obstruction. The interior space must be unified, and spaces must be connected. It is understood that one should be able to determine the exterior building layout by viewing the building from the interior. 


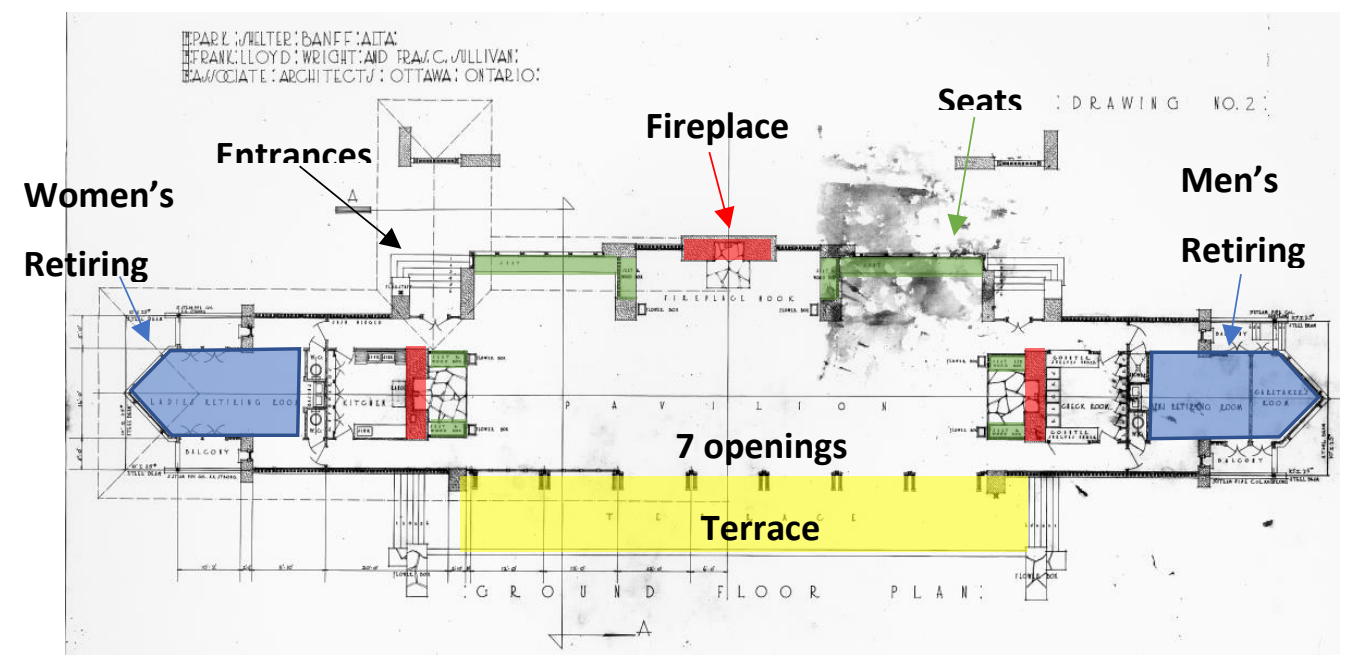

Figure 23 Banff Pavilion layout and key elements [49].

\subsubsection{Proportions}

The building and many of its elements are defined by logical and consistent proportions. Pr. Kendra Smith from Ryerson University analyzed the proportions of the Banff Pavilion using plans of the River Forest Tennis club (RFTC), where both buildings share almost identical characteristics in plan [53]. As can be seen in Figure 24 and Figure 25, it was remarked that the Banff Pavilion has proportions similar to a Tennis Court, which yields the possibility that FLW may have purposely incorporated these proportions to relate the River Forest Tennis Club to a Tennis court [53].

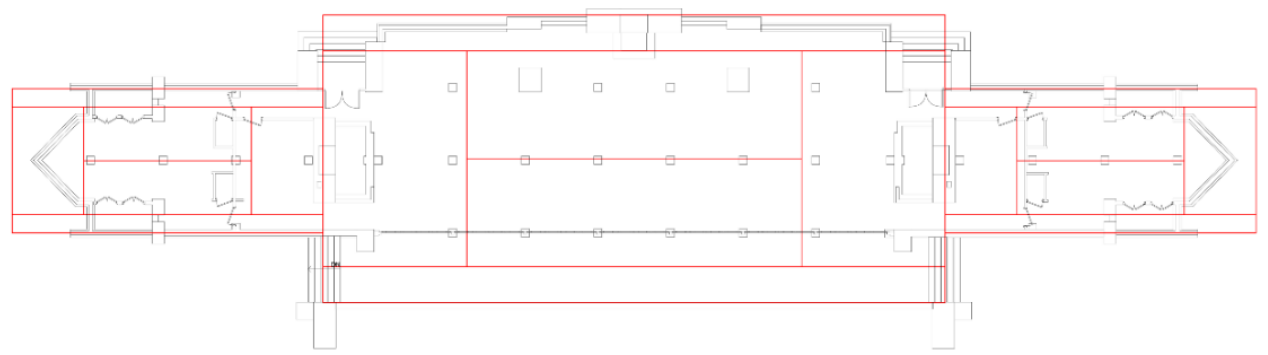

Figure 24 Plan drawing showing possible tennis court proportion in the Banff Pavilion design [53].

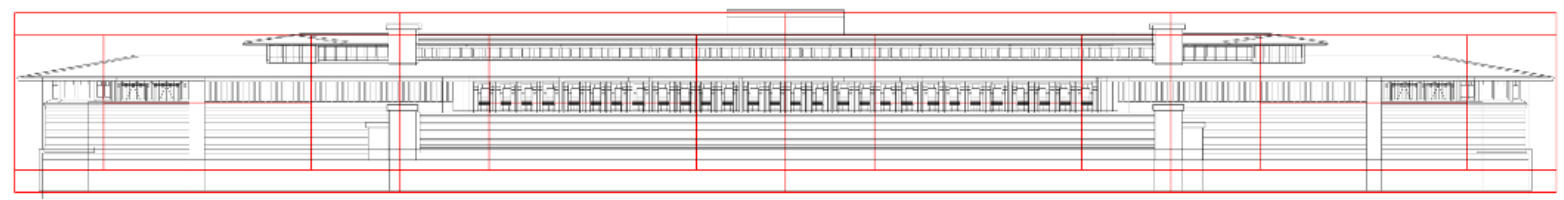

Figure 25 Elevation drawing showing possible tennis court proportion in the Banff Pavilion design [53]. 


\subsubsection{Connection to Outdoor}

The glass features connecting the inside to outside as well as the window walls leading to the terrace. Glass for his floor-to-ceiling window walls were sized in modules to line up with the other building materials, sometimes set into wood mullions continuing the line of the board-and-batten [52]. Using glass, Wright succeeded in building "broad shelter in the open," inviting nature indoors in all its guises [52].

\subsubsection{Materials}

\section{Wood}

The horizontal bands of wood shingles on the roof, the horizontal projected battens as cladding, the interior roof truss and rafters supporting the roof, the terrace flooring slats, and the interior partition screens are all character-defining wood elements.

The linearity of lumber contributes to wood's image in this regard. It is likely that he exploited the basic proportion of wood for his desire of horizontality in his buildings. Enhancing the expression of the grain would increase the plasticity of the image.

\section{Minimal Waste}

FLW claimed the minimization of waste to be a benefit of using long bands of ceiling trim, which he thought yielded "the charm of timbering without the waste" [54]. However, the waste of trees may have been of greater concern to him than the waste of clay or iron. Some of those principles could be extrapolated to today's view of construction waste. In other words, preserving the character of minimal waste would be implemented during the reconstruction of the building and get along with various sustainable programs [54]. Wright's variations on board siding detailing tended to emphasize horizontality rather than diminish it [54].

\section{Stone}

The natural face of a stone, without any cut surface. The stone should preserve its natural shape between mortar joints. Figure 26 shows how the end elevation is dominated by the stone elements, compared to the front and rear elevation, which are dominated by wooden elements. 


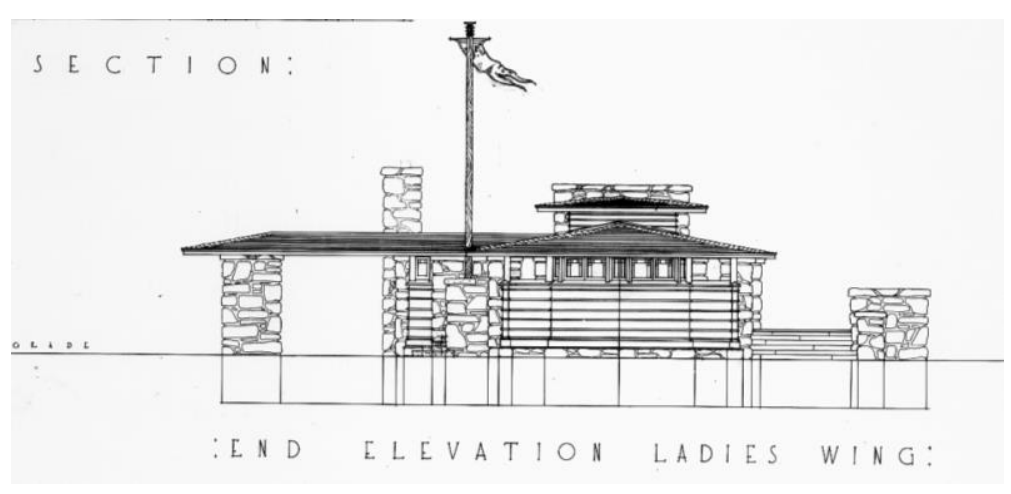

Figure 26 End Elevation Ladies Wing [49].

\section{Glass}

Glass features, including stained designs, the geometry of the patterns is essential to characterize a specific FLW building. Each FLW building has its own glass design. The ability of glass to modify light was, in his view, the root of its beauty as a visible substance [54]. Consequently, Wright used glass as a nonmaterial, in the service of vision and light, and also as the light and the vision itself. Hence, transparency is the essence of glass expression, but to maximize transparency may not necessarily mean maximum beauty [54]. The following Figure 27 shows the door sash design on the south side of the Banff Pavilion.

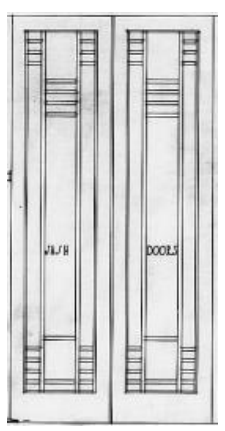

Figure 27 Door and sash design from the Banff Pavilion front elevation [49].

\section{Concrete}

The only element which features concrete is the reinforced concrete lintels at each fireplace. Another element of reinforced concrete is the slab supporting the flat flagstone hearth. This second element is not apparent and hence could be considered as a non-character defining element to be replaced by an element that provides the same function. 


\subsubsection{Roofing}

\section{Roof deck and cladding}

The gentle slope of the roof emphasizes its horizontality. In fact, when viewing the elevation plan, the sloped section of the roof is merged into the long horizontal surrounding elements, which makes it almost negligible. Also, the 4 feet cedar shingles used on the roof demonstrates the small width of parallel lines created on an elevation (see Figure 28).

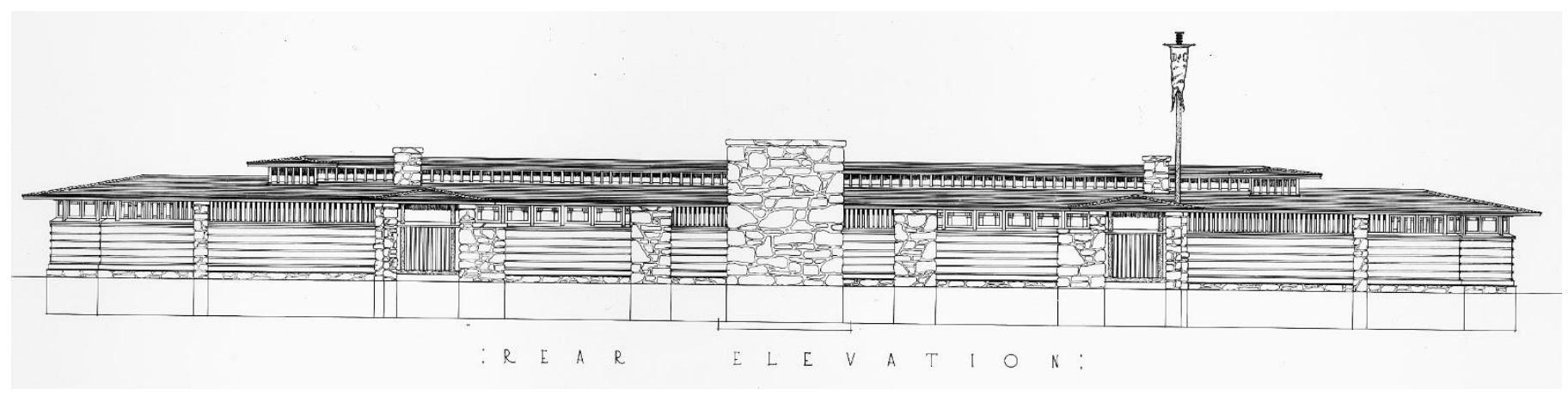

Figure 28 Rear Elevation Drawing [49].

\section{Roof structure}

As can be seen in Figure 29, the wood truss (including rafters) supporting the roof is very clearly announced on the interior. The contrast of the dark wood brown with the clear white (more or less) emphasizes the stunning appearance of the truss.

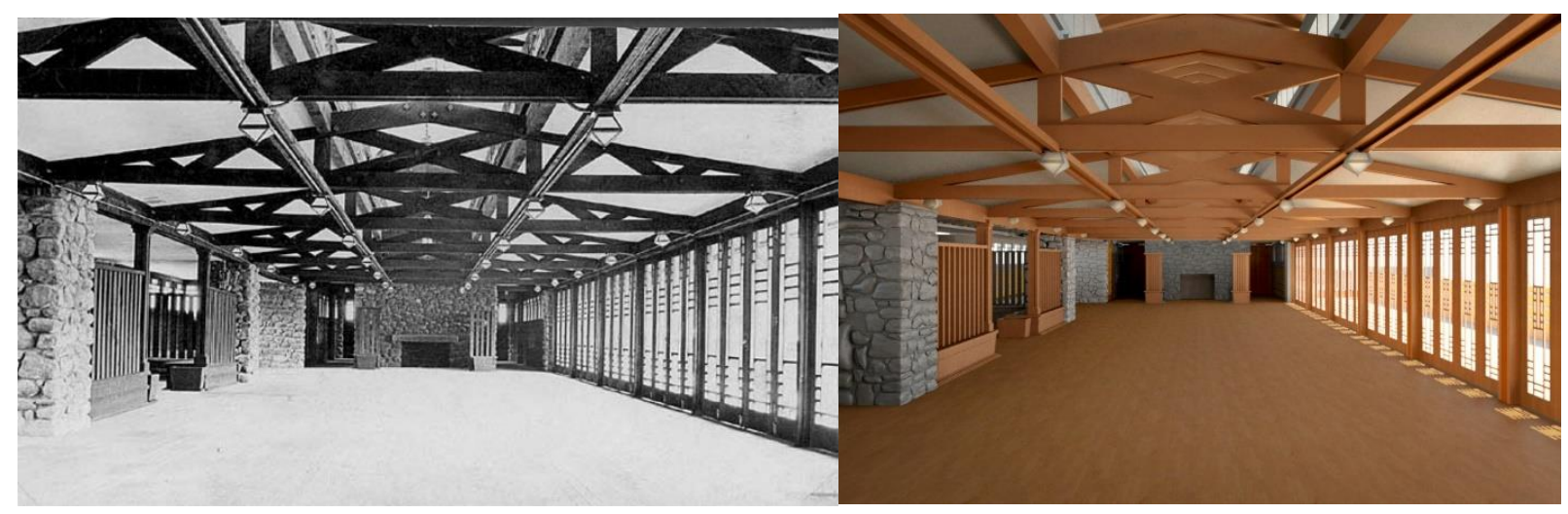

Figure 29 The original Banff Pavilion viewed from inside (left) [55] and a 3D model rendering (right) [1].

\subsubsection{Windows and Openings}

As stated in the connection to the outdoor section, windows and openings should remain as designed by FLW. The openings all have a vertical shape but form large spans of horizontal appearance due to their 
number and emphasize horizontality. The building was also used for the summer season only, providing operable windows.

\subsubsection{Ceiling}

The smooth and flat finish of the light-colored ceiling. The apparent wood truss and structure under the ceiling.

\subsubsection{Mechanical equipment}

Wright, who considered "everything in the nature of a hanging fixture a weakness and naked radiators an abomination," spent his entire career trying to build mechanical systems into the fabric of his residences. For heating, Wright emphasizes on the unity of space and suggests that the spaces be kept at equal temperature using an invisible supply equipment and that walls and doors would not be needed to contain the heat.

\subsubsection{Lighting}

For light, "the beautifier of the building," Wright took his cue from the sun, "the great luminary of all life," as he suggested in 1954 [52]. First comes the proper orientation of a house, followed by integral artificial lighting- "as near daylighting as possible." He liked the light from above, as if shone inside by the sun, and diffused to soften it in the interest of tranquillity [52].

\subsubsection{Natural Ventilation}

As the building was designed for passive summer ventilation, a key character of this building is the clerestory. The passive ventilation system shown in Figure 30 is provided by two openings that lead to an effective recirculation of air. The first opening is the sash windows hinged at the top on the front or rear façade, acting as an air inlet. The second is the vent hinges at the top of the ceiling, acting as an air outlet. Another small opening is seen in Figure 31 under the floor at the edge of the battens' exterior walls. This opening may have been used to ventilate the wood components in order to prevent high water content leading to rot and decay. 


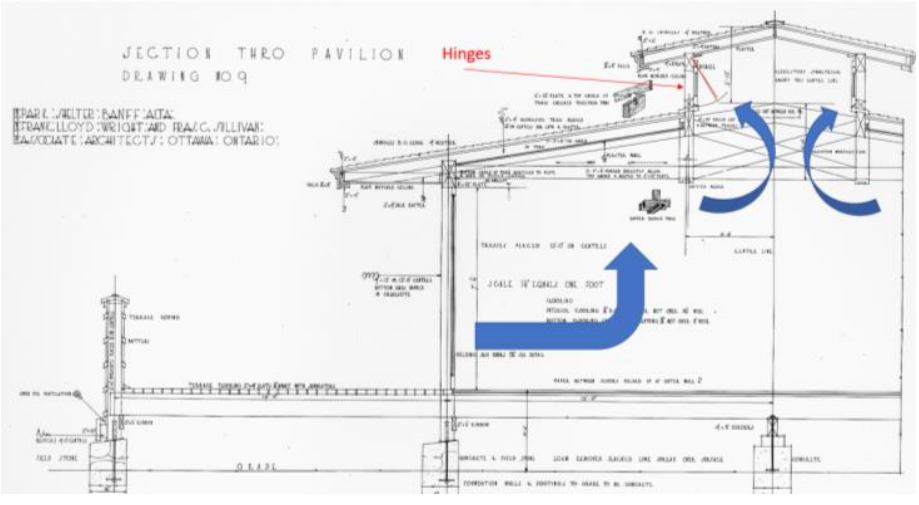

Figure 30 Cross section thro pavilion showing natural passive ventilation system [49].

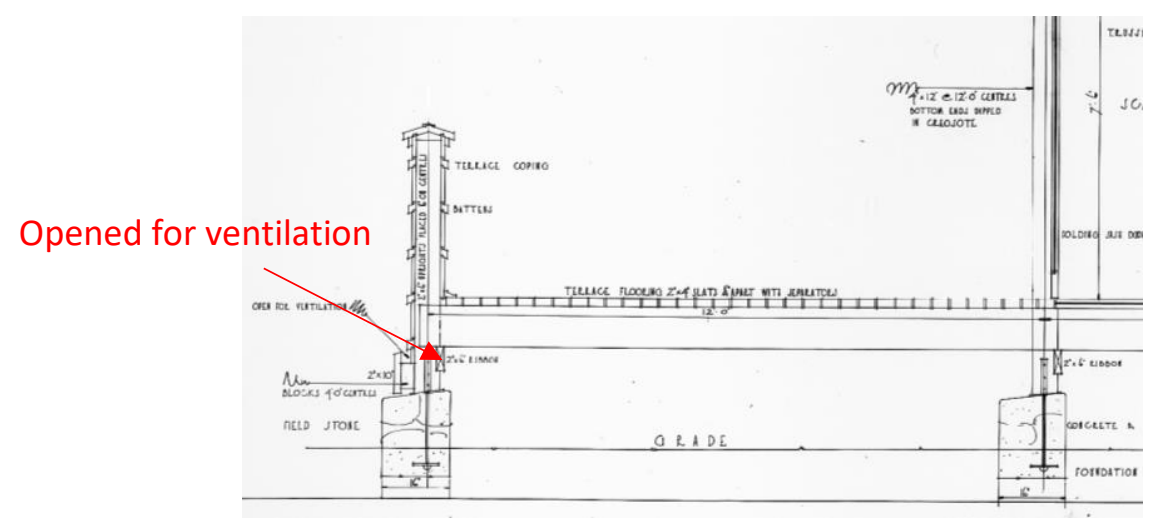

Figure 31 Cross section thro pavilion showing open ventilation system under the terrace [49].

\subsection{Character-Defining Elements and their Implications on the Building Code Requirements}

\subsubsection{Building Code - Practical Context}

In Canada, most provincial building codes are based on a model building code, which is the National Building Code (NBC) of Canada. The model building code is developed by the National Research Council of Canada (NRCC), which is independent of the provincial jurisdiction responsible for enforcing the building code.

Most of Canada's provinces adopt the NBC as a core reference to their own building code. Since the studied building is located in Banff, Calgary, the reconstruction is subject to Alberta's codes and standards. In Alberta, Safety Services is responsible for establishing and maintaining the Alberta Building Code (ABC), standards and other regulations under the Safety Codes Act [56]. The codes that are currently in force in the Building discipline in Alberta are the Alberta Building Code (2015) and the National Energy Code for Buildings (2015) [57]. 
As mentioned in the Methodology, although the Banff Pavilion is located in Alberta, it will be more convenient to use the Ontario Building Code as a reference since both the Ontario Building Code (OBC) and the Alberta Building Code are based on the National Building Code[10]. Therefore, this part of the study will consider Ontario's regulations for buildings with the Ontario Building Code (2012) as if the building were to be designed and constructed under the laws of Ontario [58].

\subsubsection{Concerned Parts of the Building Code}

Since this study is oriented from a heritage significance and a building science perspective, it will put emphasis on building science aspects, which mainly represent the hygrothermal behaviour of the building. Other affected aspects will also be stated as part of a general overview. Also, the study only focuses on code requirements that may affect the outer appearance of the character-defining elements without looking into hidden construction elements. The following Parts of the Building Code are considered:

- PART 3 Fire Protection, Occupant Safety and Accessibility

- PART 5 Environmental Separation

- PART 6 Heating, Ventilating and Air-Conditioning

- PART 9 Housing and Small Buildings

Under the Building Code's occupancy types, the Banff Pavilion would be classified as an assembly occupancy (Groupe A, Division 2). Usually, this class of buildings are not required to comply with Part 9 of the building code. However, since the studied building fulfills two of the three requirements to be subject to Part 9 and since the building construction is light wood-framed which resembles that of housing and small buildings, Part 9 will be taken as one of the references to determine the constructional approach toward the studied building. Also, it is important to note that the original Banff Pavilion was only functional during summer. However, this analysis will assume the building needs to be operated at all seasons, which implies modifying the building envelope thermal properties as well as adding HVAC systems.

\subsubsection{Character-Defining Elements in Relation to Some Areas of Part 3, 5, 6 and 9}

This section presents the areas of concern within the building code that may impact the character-defining elements design. It excludes the building envelope requirements, which are discussed in the next section. The assessment of potential restrictive requirements are shown by Building Code Part in Table B-1, Table B- 2, Table B- 3, and Table B- 4. 
Site location: Since the Banff Pavilion is located in a floodplain, item CDE-3.1 in Table B-1. shows that the building shall incorporate appropriate measures to floodproof the building. Thee are three options available which are to elevate the ground level by adding landfill, to relate the building to a flood safe field or to install a hydraulic foundation mechanism that lifts the whole building when flood hits a certain level. To preserve the CDEs related to site location and building orientation, it is essential to keep the building at the same place with the same orientation including the view towards the mountains and the accessibility to the Bow River. It is also typical to FLW design to keep the low building height in prairiestyle design, which deems adding landfill to the ground level unacceptable. Hence, unless flood issues are concerned on a landscape and planning scale, the only acceptable solution would be the third option, installing a hydraulic foundation mechanism (refer to Figure A- 1 for an actual example).

Interior spaces: A building in heavy timber roof structure has restrictions as the truss members require a minimum thickness which is larger than the original wood truss. This would alter the character of the interior space which may appear unproportioned or even narrower than intended. It has been shown that FLW emphasis on the width of an interior space. Another issue that would arise in fire protection requirements is the sprinkler system, which would be intrusive to the interior spaces, especially knowing that FLW used to hide any electrical or mechanical fixtures.

Building Shape and Proportions: In the roofing section of Part 9, it is required that wood shingles must have a minimum slope of 1 in 4 . However, as seen in Figure 32 and Figure 33, the slope of the roof is approximately 1 in 6 based on the original drawings which is less than the minimum requirement. An increase in the slope of the roof will alter the horizontality and flattened shape of the building, which are emphasised as main characters in FLW prairie-style buildings.

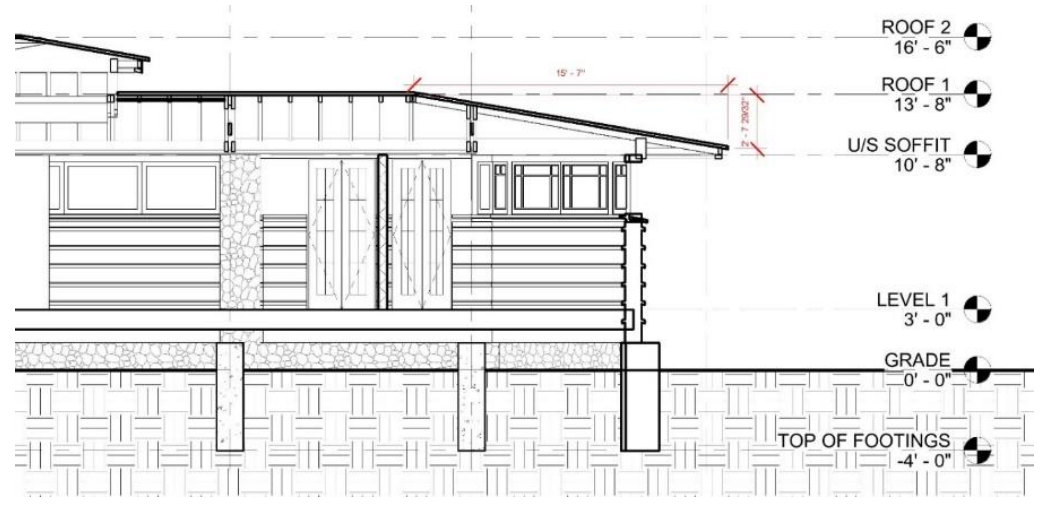

Figure 32 Cut section on the east side of the Banff Pavilion showing the slope (1 in 6) of the roof in an east-west axis. 


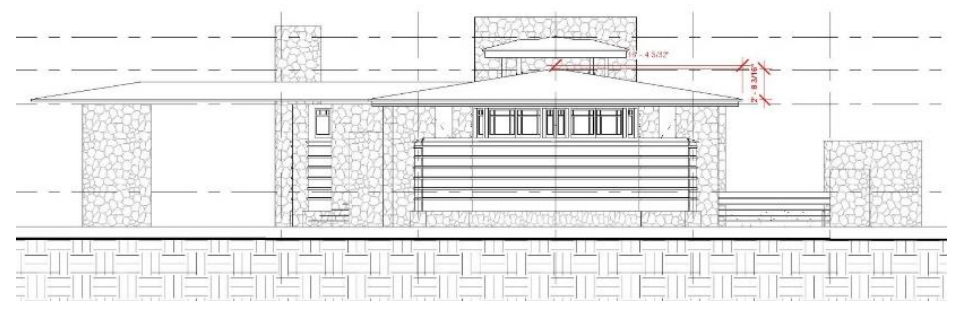

Figure 33 Elevation on the west side of the building showing the slope (1 in 6$)$ of the roof in a south-north axis.

\subsubsection{Character-Defining Elements in Relation to Specific Building Envelope Requirements}

\subsubsection{Prescriptive Approach vs Trade-off Approach}

This section analyses the character-defining elements that involve building envelope requirements. The Building Code Section 6.2.1.1. implies that good engineering practice for heating, ventilating, and airconditioning systems be designed and constructed according to different ASHRAE Handbooks and among them the ANSI/ASHRAE/IESNA 90.1 Energy Standard for Buildings Except Low-Rise Residential Buildings. Furthermore, the ASHRAE 90.1 standard will regulate this analysis. The Building Envelope section 5.5 of ASHRAE 90.1 describes two possible compliance methods, which are the Prescriptive Building Envelope Option, and the Building Envelope Trade-Off Option [59]. The prescriptive approach is a strict set of requirements that, in case any of the items are not met, the building cannot comply with the standard. Therefore, this approach may not be able to accommodate the original design of the Banff Pavilion, including all its character-defining elements. However, the trade-off approach is an alternative option based on performance factors determined by energy modelling. This approach allows some envelope components to be traded off with other prescriptive requirements within the building envelope section. Consequently, the analysis for such a situation is a comparison between a baseline building performance using the prescriptive option and a proposed building performance using the trade-off option.

\subsubsection{Energy Cost Budget Method}

Another alternative to the prescriptive approach is the Energy Cost Budget Method (ECM), which is also a performance path. A similar comparison is made between the baseline energy cost budget (ECB) and the proposed building design energy-cost. Distinctively, this approach involves many major building components affecting energy use, such as the building envelope, the HVAC systems, the service water heating and the lighting. At the same time, it allows for trade-offs between prescriptive components regardless of their sections, which gives it more flexibility. However, the complexity of this path and its variety of building domains places it out of the scope of this analysis. 


\subsubsection{Prescriptive Building Envelope Option}

This section determines the baseline design of the assembly and openings for the wall and roof, as required in section 5.5 of ASHRAE 90.1. As per the National Energy Code for Buildings, the city of Banff is classified in climate zone 7a with approximately 5500 heating degree days [60]. The prescriptive requirements for the exterior building envelope assemblies, including roof, above-grade walls, floors, windows, and skylights are stated in Table 1 for climate zone 7. The supplementary standard SB-10 requirements are shown for comparison, although the standard is not part of the scope of this study.

Table 1 Building Envelope minimum requirements for non-residential occupancy as per ASHRAE 90.1 and SB-10 [59],[61].

\begin{tabular}{|c|c|c|c|c|}
\hline & & $\begin{array}{l}\text { Assembly } \\
\text { Maximum }\end{array}$ & \multicolumn{2}{|c|}{$\begin{array}{c}\text { Insulation } \\
\text { Min. } R \text {-Value }\end{array}$} \\
\hline & & SI units (IP units) & Sl units & IP units \\
\hline Standard & \multicolumn{4}{|l|}{ Roofs } \\
\hline ASHRAE 90.1 & \multirow{2}{*}{ Insulation Entirely above Deck } & $U-0.158(0.028)$ & $R-6.2$ c.i. & 35 c.i. \\
\hline$S B-10$ & & $U-0.143(0.025)$ & 7.0 c.i. & 40 c.i. \\
\hline \multirow[t]{2}{*}{ ASHRAE 90.1} & Attic and Other & $U-0.098(0.017)$ & $R-10.6$ & $R-60$ \\
\hline & \multicolumn{4}{|l|}{ Walls, above Grade } \\
\hline ASHRAE 90.1 & \multirow[t]{2}{*}{ Wood Framed and Other } & $U-0.291(0.051)$ & $\begin{array}{c}\text { R-2.3 + R-1.3 c.i. or } \\
\text { R-3.3 + R-0.9 c.i. }\end{array}$ & $\begin{array}{c}13+7.5 \text { c.i. or } \\
19+5 \text { c.i. }\end{array}$ \\
\hline \multirow[t]{2}{*}{$S B-10$} & & $U-0.261(0.046)$ & $2.3+1.8 \mathrm{ci}$ & $13+10.2$ c.i. \\
\hline & \multicolumn{4}{|l|}{ Wall, below Grade } \\
\hline ASHRAE 90.1 & \multirow{2}{*}{ Below Grade Wall } & $C-0.358(0.063)$ & $R-2.6$ c.i. & 15 c.i. \\
\hline \multirow[t]{2}{*}{$S B-10$} & & $C-0.284(0.050)$ & $3.5 \mathrm{ci}$ & 19.9 \\
\hline & \multicolumn{4}{|l|}{ Floors } \\
\hline ASHRAE 90.1 & \multirow{2}{*}{ Wood Framed and Other } & U-0.153 (0.027) & $R-6.7$ & 38 \\
\hline \multirow[t]{2}{*}{$S B-10$} & & $U-0.138(0.024)$ & $6.7+0.5 \mathrm{ci}$ & $38+2.8$ c.i. \\
\hline & \multicolumn{2}{|l|}{ Opaque Doors } & & \\
\hline ASHRAE 90.1 & \multirow{2}{*}{ Swinging } & $U-2.839(0.50)$ & - & - \\
\hline \multirow[t]{3}{*}{$S B-10$} & & $U-2.56(0.45)$ & - & - \\
\hline & \multicolumn{4}{|l|}{ Fenestration } \\
\hline & $\begin{array}{l}\text { Vertical Fenestration, } \\
0 \%-40 \% \text { of Wall }\end{array}$ & $\begin{array}{c}\text { Assembly } \\
\text { Max. U-value }\end{array}$ & $\begin{array}{c}\text { Assembly } \\
\text { Max. } \\
\text { SHGC }\end{array}$ & $\begin{array}{c}\text { Assembly } \\
\text { Min. } \\
\text { VT/SHGC }\end{array}$ \\
\hline ASHRAE 90.1 & \multirow{2}{*}{ Nonmetal framing, all } & $U-1.82(0.32)$ & \multirow{2}{*}{0.45} & \multirow{2}{*}{1.1} \\
\hline \multirow[t]{2}{*}{$S B-10$} & & $U-1.64(0.029)$ & & \\
\hline & \multicolumn{4}{|l|}{ Skylight, 0\%-3\% of Roof } \\
\hline ASHRAE 90.1 & \multirow{2}{*}{ All types } & $U-2.84(0.50)$ & - & - \\
\hline$S B-10$ & & $U-2.56(0.45)$ & - & - \\
\hline
\end{tabular}




\subsection{Constructional Approach to Wood-frame Walls and Roof Assemblies}

First, in order to determine how to comply with both the Prescriptive and the Trade-Off approaches of ASHRAE 90.1, it is necessary to assess the building envelope design options which present various assembly details. There are different construction methods for wood-framed walls and roof assemblies, the following figures present the common best practice assemblies. In this study, the baseline building is narrowed to one prescriptive design option.

\subsubsection{Character-defining elements and sections details}

When looking at a wall or roof assembly section detail, it is evident that the layer which has the potential to compromise the character-defining elements is the thickness of the insulation. Hence, the variable of interest is the thermal resistance requirements in relation to the insulation thickness. Another important aspect is the location of the insulation within the assembly and the configuration of the assembly itself. To narrow the scope, the vapour resistance and air barrier requirements are only considered as mandatory items without further investigation and analysis. The Guide for Designing Energy-Efficient Building Enclosures Table 2 presents typical insulation products with their thermal resistance (R-value) per unit of thickness. These values are important in order to assess all insulation configurations within an assembly. 
Table 2 Various insulation types with R-value range, vapour permeability, and air permeability [62].

\begin{tabular}{|c|c|c|c|c|}
\hline Insulation type & Typical use & $\begin{array}{l}\text { R-value/inch } \\
\text { [R-value (RSI)] }\end{array}$ & $\begin{array}{l}\text { Vapour } \\
\text { Permeability }\end{array}$ & $\begin{array}{c}\text { Air } \\
\text { Permeability }\end{array}$ \\
\hline \multicolumn{5}{|l|}{ Fibreglass } \\
\hline Batts & $\begin{array}{l}\text { Stud cavities, between } \\
\text { attic trusses }\end{array}$ & $\begin{array}{c}\text { R-3.0 to } 4.2 \\
\text { (0.53 to } 0.75 \text { ) }\end{array}$ & High & High \\
\hline Blown fibres & $\begin{array}{l}\text { Blown into stud cavities, } \\
\text { attic loose-fill }\end{array}$ & $\begin{array}{c}R-2.5 \text { to } 3.7 \\
(0.44 \text { to } 0.65)\end{array}$ & High & High \\
\hline Dense pack & Sprayed into stud cavities & $\begin{array}{l}R-3.5 \text { to } 4.0 \\
(0.62 \text { to } 0.70)\end{array}$ & High & High \\
\hline Semi-rigid board & $\begin{array}{l}\text { Exterior cavities exposed } \\
\text { to dampness, window } \\
\text { spandrel panels }\end{array}$ & $\begin{array}{l}R-3.5 \text { to } 4.2 \\
(0.62 \text { to } 0.75)\end{array}$ & High & High \\
\hline \multicolumn{5}{|l|}{ Mineral or rock fibre } \\
\hline Batts & Stud cavities & $\begin{array}{l}\text { R-3.0 to } 4.2 \\
\text { (0.53 to } 0.75)\end{array}$ & High & High \\
\hline $\begin{array}{l}\text { Rigid and semi-rigid } \\
\text { board }\end{array}$ & $\begin{array}{l}\text { Exterior cavities exposed } \\
\text { to dampness, window } \\
\text { spandrel } \\
\text { fire-stopping }\end{array}$ & $\begin{array}{l}\mathrm{R}-3.5 \text { to } 4.3 \\
(0.62 \text { to } 0.76)\end{array}$ & High & High \\
\hline \multicolumn{5}{|l|}{ Cellulose } \\
\hline Blown fibres & $\begin{array}{l}\text { Stud cavities, attic } \\
\text { loose-fill }\end{array}$ & $\begin{array}{l}\text { R-3.0 to } 3.8 \\
\text { (0.53 to } 0.67)\end{array}$ & High & High \\
\hline Dense pack & Sprayed into stud cavities & $\begin{array}{l}R-3.5 \text { to } R-3.8 \\
(0.62 \text { to } 0.67)\end{array}$ & High & Medium \\
\hline $\begin{array}{l}\text { Extruded polystyrene } \\
\text { (XPS): rigid board }\end{array}$ & $\begin{array}{l}\text { Sheathing, roofing (where } \\
\text { exposed to water), below } \\
\text { grade, below slab, cavities } \\
\text { exposed to dampness }\end{array}$ & $\begin{array}{l}\text { R-5.0 to } 5.6 \\
\text { - R-5.0 typical } \\
\text { (0.88 to } 1.0)\end{array}$ & Low & Low \\
\hline $\begin{array}{l}\text { Expanded polystyrene } \\
\text { (EPS): rigid board }\end{array}$ & $\begin{array}{l}\text { Sheathing, roofing (where } \\
\text { protected from water), } \\
\text { below grade, cavities, } \\
\text { EIFS, insulated concrete } \\
\text { forms (ICFs) }\end{array}$ & $\begin{array}{l}R-3.7 \text { to } 4.3 \\
(0.65 \text { to } 0.76)\end{array}$ & Low & Low \\
\hline $\begin{array}{l}\text { Polyisocyanurate: rigid } \\
\text { board, foil, or } \\
\text { fibreglass faced }\end{array}$ & $\begin{array}{l}\text { Roofing, sheathing, and } \\
\text { wall cavities (where } \\
\text { protected from water) }\end{array}$ & $\begin{array}{l}\text { R-5.0 to } 6.0 \text { aged } \\
\text { (0.88 to } 1.06)\end{array}$ & Low & Low \\
\hline \multicolumn{5}{|l|}{ Spray polyurethane foam } \\
\hline $\begin{array}{l}\text { 1/2-pound, low-density, } \\
\text { open-cell }\end{array}$ & $\begin{array}{l}\text { Stud cavities, attics below } \\
\text { sheathing }\end{array}$ & $\begin{array}{l}R-3.6 \text { to } 3.8 \\
(0.63 \text { to } 0.67)\end{array}$ & High & Low \\
\hline $\begin{array}{l}\text { 2-pound, high-density, } \\
\text { closed-cell }\end{array}$ & $\begin{array}{l}\text { Exterior of sheathing, } \\
\text { attics below sheathing, } \\
\text { below-grade, air ceiling } \\
\text { floor/roof joists, and other } \\
\text { difficult-to-insulate/seal } \\
\text { locations }\end{array}$ & $\begin{array}{l}\text { R-5.0 to } 6.0 \text { aged } \\
\text { (0.88 to } 1.06)\end{array}$ & Low & Low \\
\hline
\end{tabular}

\subsubsection{Wall Assembly}

The Guide for Designing Energy-Efficient Building Enclosures presents in Figure 34 typical above-grade wood-frame wall assemblies with different insulation types. For the purpose of this study, the standard $2 \times 6$ stud wall is considered as it represents the original design of the Banff Pavilion. Table 3 presents the thermal resistance for various installed insulation options in $2 \times 6$ wood frame walls and their corresponding minimum thickness to comply with the wood-frame wall prescriptive minimum requirements as stated in Table 1. 


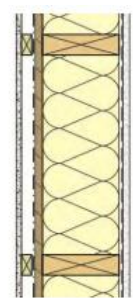

$2 \times 6$ stud wall

Interior-insulated wall assemblies

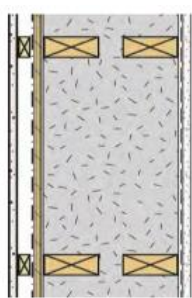

Double-stud wall

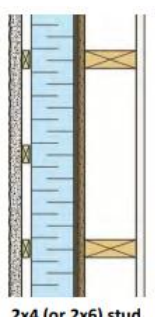

$2 \times 4$ (or $2 \times 6$ ) stud wall

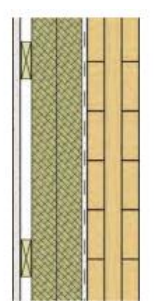

$\mathrm{CLT} / \mathrm{mass}$ timb

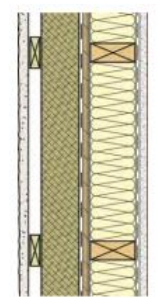

$2 \times 4$ (or $2 \times 6$ ) stud wall Split-insulated wall
assembly

Figure 34 Typical above-grade wood-frame wall assemblies with different insulation types [62].

As can be seen in Table 3, the total thickness of the insulation including both cavity and continuous insulation will require to be at a minimum of 7 inches (Polyisocyanurate is not considered since it is temperature dependant and the R-value may vary from one manufacturer to another) [63]. However, Figure 35 shows that the original design of the wall assembly is set to allow for a maximum of 6 inches of insulation. Figure 36 to Figure 39 show typical best practice wall assemblies for wood-frame construction applied to the original section details to the Banff Pavilion. These figures relate to the options presented in Table 3. The fiberglass $2 \times 6$ wall with XPS added continuous insulation shown in Figure 36 is considered moving forward for the energy modeling simulation. 
Table 3 The thermal resistance for various installed insulation options in $2 \times 6$ wood frame walls and their corresponding minimum thickness to comply with prescriptive requirements.

\begin{tabular}{|c|c|c|c|c|c|}
\hline $\begin{array}{l}\text { Cavity } \\
\text { Insulation }\end{array}$ & $\begin{array}{l}\text { Added } \\
\text { continuous } \\
\text { insulation }\end{array}$ & $\begin{array}{l}\text { Installed } \\
\text { R-value } \\
\text { for } 2 \times 6 \\
\text { stud cavity }\end{array}$ & $\begin{array}{l}\text { Continuous } \\
\text { insulation R-value }\end{array}$ & $\begin{array}{l}\text { Minimum added } \\
\text { c.i. thickness to } \\
\text { achieve R-5 } \\
\text { prescriptive } \\
\text { requirements } \\
\text { (in) }\end{array}$ & $\begin{array}{l}\text { Total } \\
\text { minimum } \\
\text { insulation } \\
\text { thickness } \\
\text { (in) }\end{array}$ \\
\hline \multicolumn{6}{|c|}{ SI units (IP units) } \\
\hline \multirow{3}{*}{$\begin{array}{l}\text { Fiberglass batt } \\
\text { or cellulose }\end{array}$} & EPS & \multirow{3}{*}{$\begin{array}{c}\text { RSI-3.35 to } \\
3.7 \\
\text { (R-19.0 to } \\
21)^{1}\end{array}$} & $\begin{array}{l}\text { RSI-0.28/cm } \\
\text { (R-4/inch) }^{1}\end{array}$ & $31.75(1.25)$ & $184.2(7.25)$ \\
\hline & XPS & & $\begin{array}{l}\text { RSI-0.35/cm } \\
\text { (R-5/inch) }^{1}\end{array}$ & $25.4(1.00)$ & $\begin{array}{l}177.8 \\
(7.0)\end{array}$ \\
\hline & Polyisocyanurate & & $\begin{array}{c}\mathrm{RSI}-0.45 / \mathrm{cm} \\
\text { (R-6.5/inch)* } 1\end{array}$ & $19.56(0.77)$ & $172.0(6.77)$ \\
\hline $\begin{array}{l}\text { Spray foam } \\
\text { (high density) }\end{array}$ & None & $\begin{array}{l}\text { RSI-5.28 } \\
(\mathrm{R}-30)^{2}\end{array}$ & $\begin{array}{l}\text { RSI-0.35/cm } \\
\text { (R-5/inch) }{ }^{1}\end{array}$ & $25.4(1.0)$ & $\begin{array}{l}177.8 \\
(7.0)\end{array}$ \\
\hline Cellulose & $\begin{array}{c}\text { Mineral Fiber } \\
\text { Bords }\end{array}$ & $\begin{array}{l}\text { RSI-3.52 } \\
(\mathrm{R}-20)^{3}\end{array}$ & $\begin{array}{l}\text { RSI-0.26-0.30/cm } \\
\left(\mathrm{R}-3.8-4.3 / \text { inch }^{3}\right.\end{array}$ & $\begin{array}{c}33.53-29.46 \\
(1.32-1.16)\end{array}$ & $\begin{array}{l}185.9-181.9 \\
(7.32-7.16)\end{array}$ \\
\hline $\begin{array}{l}\text { SIP with EPS } \\
\text { (Type 1) core }\end{array}$ & XPS & $\begin{array}{l}\text { RSI-3.7 } \\
(\mathrm{R}-21)^{4}\end{array}$ & $\begin{array}{l}\text { RSI-0.35/cm } \\
\text { (R-5/inch) }^{1}\end{array}$ & $25.4(1.0)$ & $\begin{array}{l}177.8 \\
(7.00)\end{array}$ \\
\hline $\begin{array}{l}\text { SIP with XPS } \\
\text { (Type 4-5) } \\
\text { core* }\end{array}$ & XPS & $\begin{array}{l}\text { RSI-5.28 } \\
(\mathrm{R}-30)^{4}\end{array}$ & $\begin{array}{c}\text { RSI-0.35/cm } \\
\text { (R-5/inch) }^{1}\end{array}$ & $25.4(1.0)$ & $\begin{array}{l}177.8 \\
(7.00)\end{array}$ \\
\hline $\begin{array}{l}\text { SIP with PU } \\
\text { core* }\end{array}$ & XPS & $\begin{array}{l}\text { RSI-7.22 } \\
(\mathrm{R}-41)^{4}\end{array}$ & $\begin{array}{l}\text { RSI-0.35/cm } \\
\text { (R-5/inch) }^{1}\end{array}$ & $25.4(1.0)$ & $\begin{array}{l}177.8 \\
(7.00)\end{array}$ \\
\hline
\end{tabular}

${ }^{*} \mathrm{R}$-values vary between manufacturers; tests must be done to reflect the effect of aging of the product.
1. [64]
2. [65]
3. [66]
4. [67] 


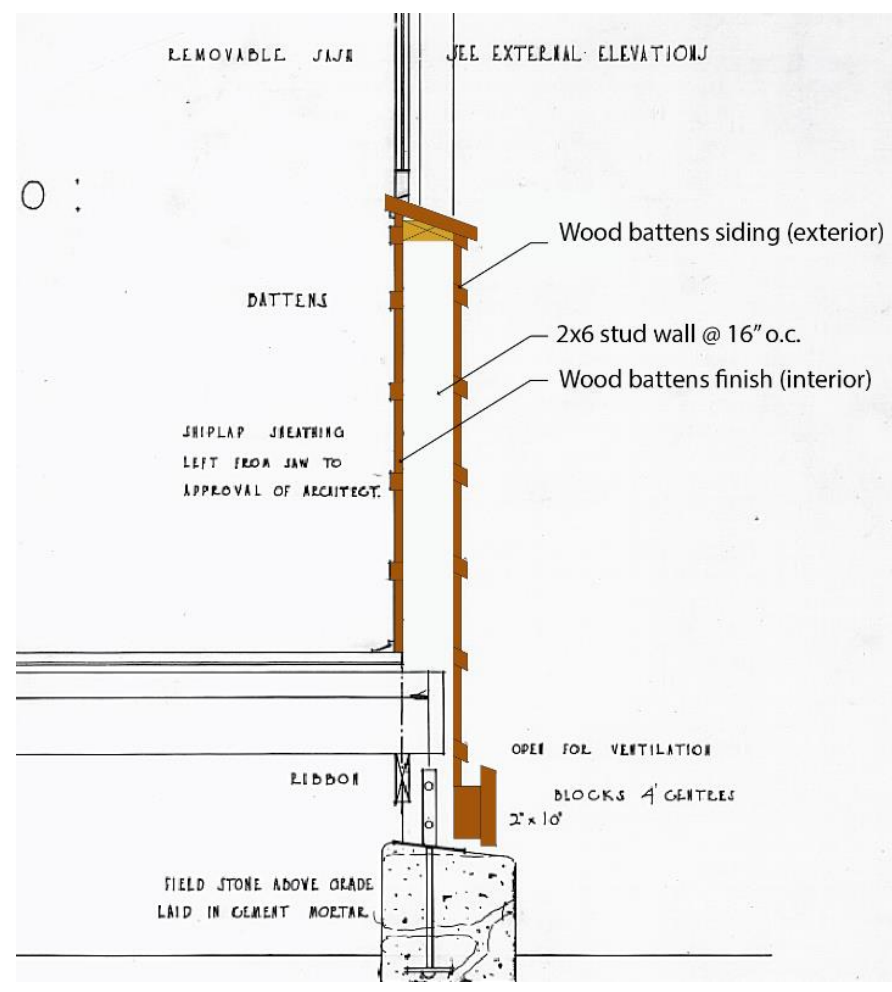

Figure 35 Original Banff Pavilion wall section detail [49].

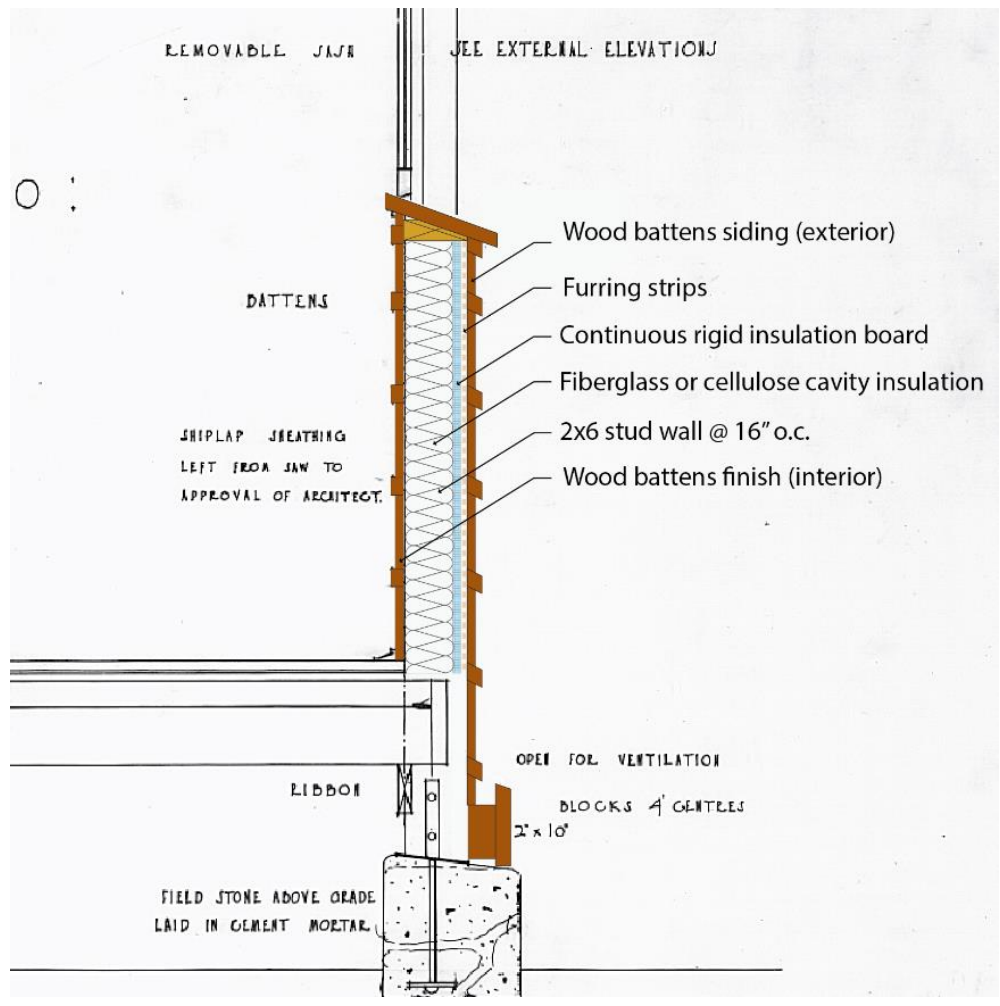

Figure 36 Overview summarizing XPS on $2 \times 6$ wood frame wall construction [64]. 


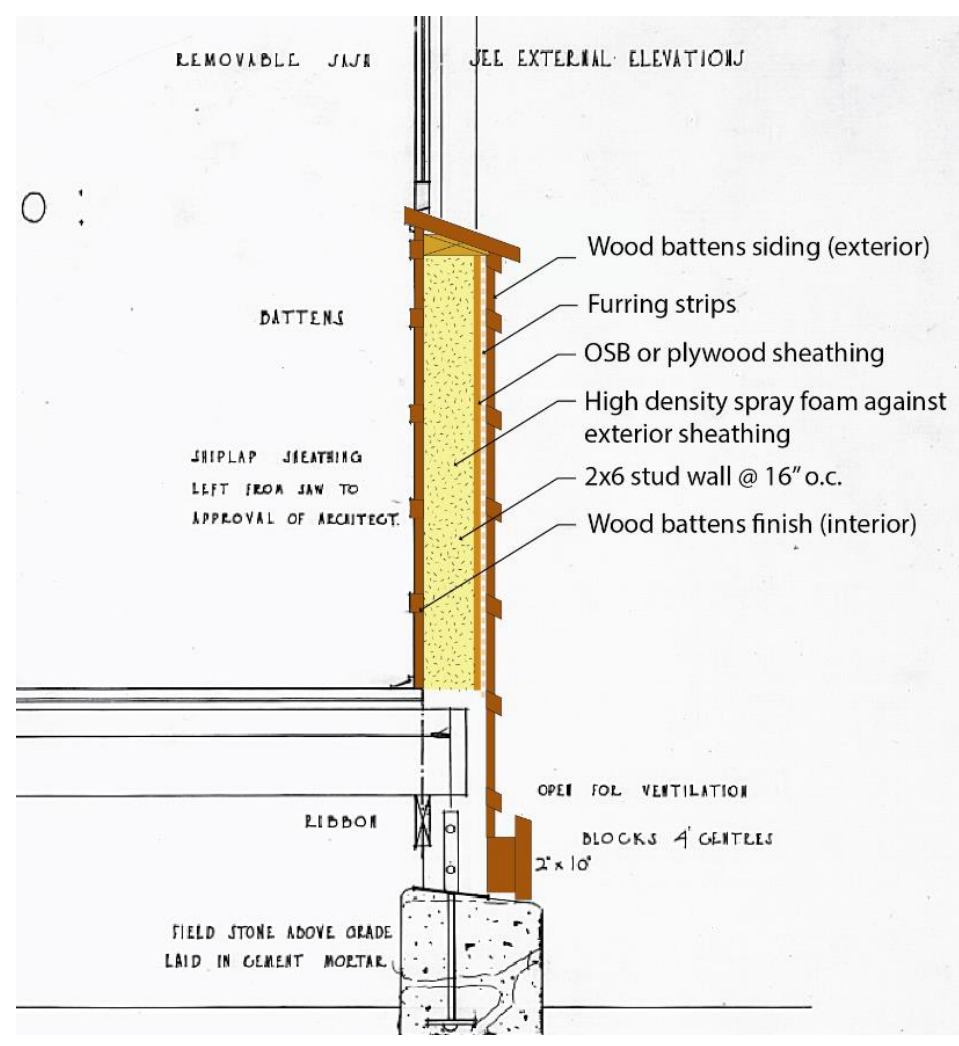

Figure 37 Overview summarizing spray foam on $2 \times 6$ wood frame wall construction [65].

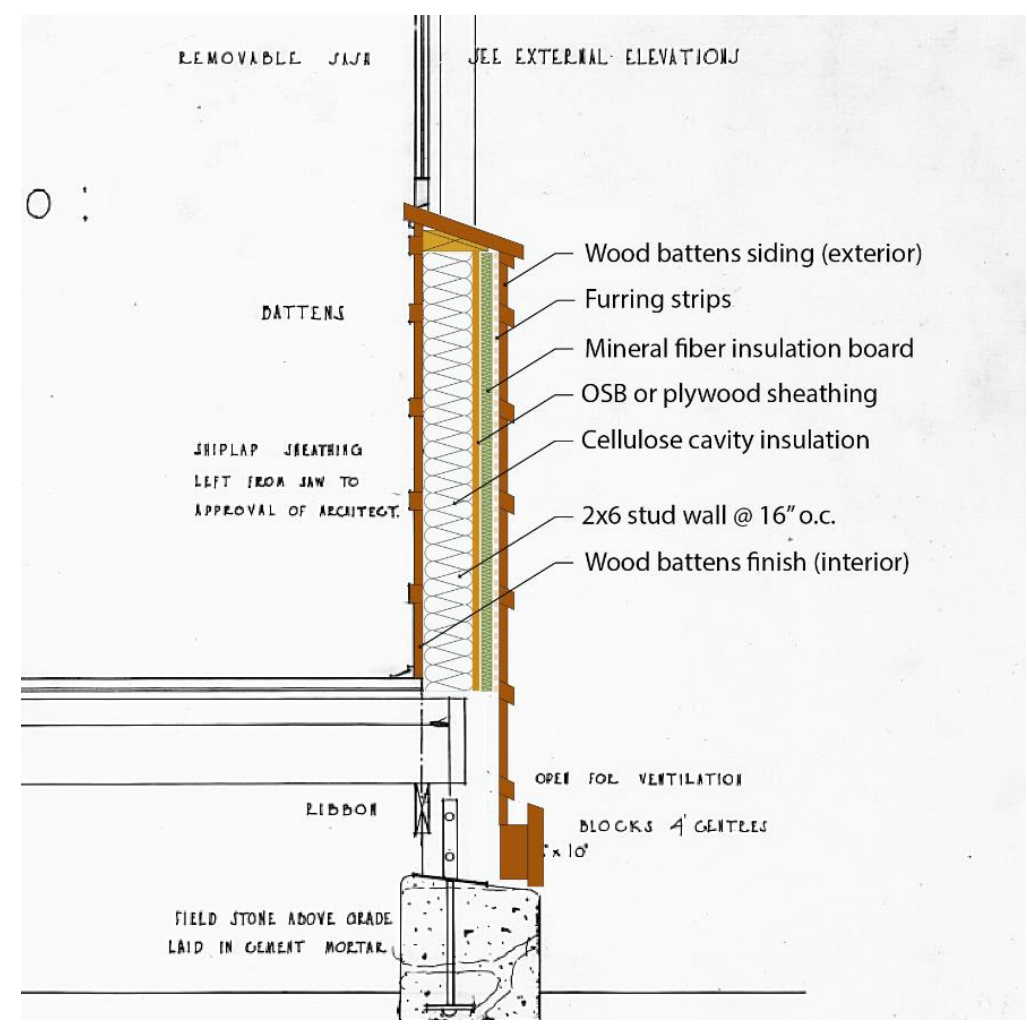

Figure 38 Overview summarizing $2 \times 6$ wood-frame wall assembly with mineral fiber insulation boards [66]. 


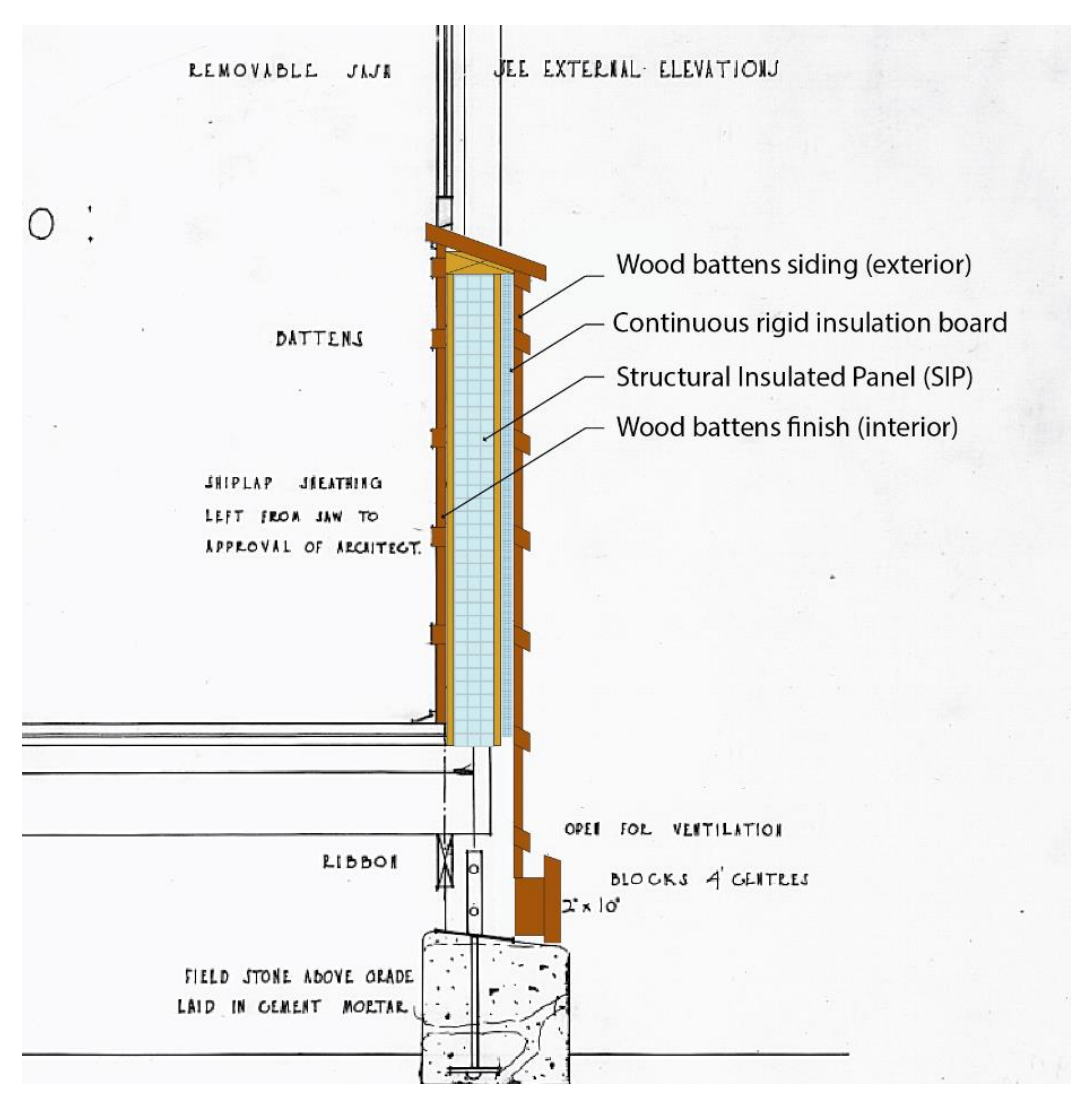

Figure 39 Overview summarizing SIPs wall construction [68].

\subsubsection{Sloped Roof Assembly}

The pitched roof assembly options are few. Two common pitched roof assemblies are the unvented assembly with insulation below and on top of the roof deck (Figure 41 and Figure 42) and the unvented assembly with insulation entirely above deck (Figure 43), where a vented space can be added to prevent ice-damming (Figure 44). As can be seen in Figure 40, the original 1900s design of the roof assembly shows that the ceiling (lath and plaster) is placed at 4 inches below the roof deck, which can be seen from the interior in Figure 29. This allows todays construction to incorporate cavity insulation in between the ceiling and the roof deck. However, given the current requirements for the roof assembly which prescribes R-35 of continuous insulation for insulation entirely above deck or R-60 for other types of assemblies, it is quite challenging to satisfy one of the requirements while preserving the character-defining elements retrieved in the roof assembly. Table 4 shows the thermal resistance for various installed insulation options in roof assemblies and their corresponding minimum thickness to comply with prescriptive requirements. These options are illustrated in Figure 40 to Figure 43. It can be concluded that Polyisocyanurate and XPS insulation that are placed entirely above deck will add the least intrusive thickness with values 
of 5.38 inches (6 inches nominal) and 7 inches respectively. The energy model will then use 6 inches of continuous Polyisocyanurate boards above deck.

Table 4 The thermal resistance for various installed insulation options in roof assemblies and their corresponding minimum thickness to comply with prescriptive requirements.

\begin{tabular}{|c|c|c|c|c|}
\hline Cavity Insulation & $\begin{array}{l}\text { Continuous } \\
\text { insulation above } \\
\text { roof deck }\end{array}$ & $\begin{array}{l}\text { Installed } \\
\text { R-value in the } \\
4 \text { inches rafter } \\
\text { cavity }\end{array}$ & $\begin{array}{l}\text { Continuous } \\
\text { insulation } \\
\text { R-value }\end{array}$ & $\begin{array}{l}\text { Minimum added } \\
\text { c.i. thickness to } \\
\text { achieve prescriptive } \\
\text { requirements }\end{array}$ \\
\hline \multicolumn{5}{|c|}{ SI units (IP units) } \\
\hline \multicolumn{5}{|c|}{ R-60 whole assembly requirement } \\
\hline \multirow{3}{*}{ Fiberglass batt } & EPS & \multirow{3}{*}{$\begin{array}{c}\text { RSI-2.11 to } 2.96 \\
\text { (R-12 to } 16.8)\end{array}$} & $\begin{array}{l}\text { RSI-0.28/cm } \\
\text { (R-4/inch) }\end{array}$ & $\begin{array}{c}304.8-10.8 \mathrm{~mm} \\
(12-10.8 \mathrm{in})\end{array}$ \\
\hline & XPS & & $\begin{array}{l}\text { RSI-0.35/cm } \\
\text { (R-5/inch) }\end{array}$ & $\begin{array}{l}243.8-8.64 \mathrm{~mm} \\
(9.60-8.64 \mathrm{in})\end{array}$ \\
\hline & Polyisocyanurate & & $\begin{array}{l}\text { RSI-0.45/cm } \\
\text { (R-6.5/inch)* }\end{array}$ & $\begin{array}{l}187.4-6.64 \mathrm{~mm} \\
(7.38-6.64 \mathrm{in})\end{array}$ \\
\hline $\begin{array}{l}\text { High density spray } \\
\text { foam }\end{array}$ & XPS & $\begin{array}{c}\text { RSI-3.52 to } 4.23 \\
\text { (R-20 to } 24)\end{array}$ & $\begin{array}{l}\text { RSI-0.35/cm } \\
\text { (R-5/inch) }\end{array}$ & $\begin{array}{l}203.2-7.2 \mathrm{~mm} \\
(8.00-7.20 \mathrm{in})\end{array}$ \\
\hline \multicolumn{5}{|c|}{ R-35 c.i. requirement for insulation entirely above deck } \\
\hline \multirow{3}{*}{ None } & EPS & - & $\begin{array}{c}\text { RSI-0.28/cm } \\
\text { (R-4/inch) }\end{array}$ & $\begin{array}{l}222.3 \mathrm{~mm} \\
(8.75 \mathrm{in})\end{array}$ \\
\hline & XPS & - & $\begin{array}{c}\text { RSI-0.35/cm } \\
\text { (R-5/inch) }\end{array}$ & $\begin{array}{c}177.8 \mathrm{~mm} \\
(7.00 \mathrm{in})\end{array}$ \\
\hline & Polyisocyanurate & - & $\begin{array}{l}\text { RSI-0.45/cm } \\
\text { (R-6.5/inch)* }\end{array}$ & $\begin{array}{l}136.7 \mathrm{~mm} \\
(5.38 \mathrm{in})\end{array}$ \\
\hline
\end{tabular}

*R-values vary between manufacturers; tests must be done to reflect the effect of aging of the product. 


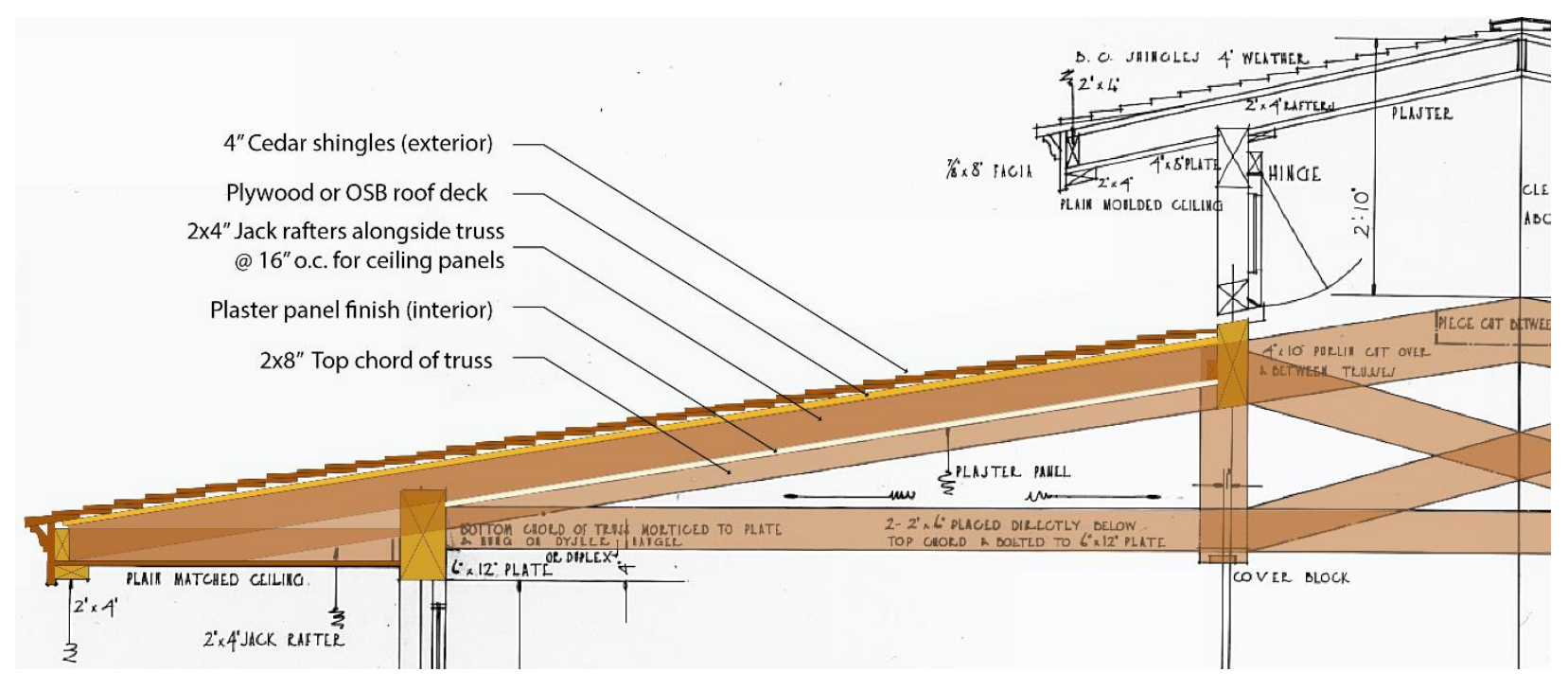

Figure 40 Original Banff Pavilion roof section detail [49].

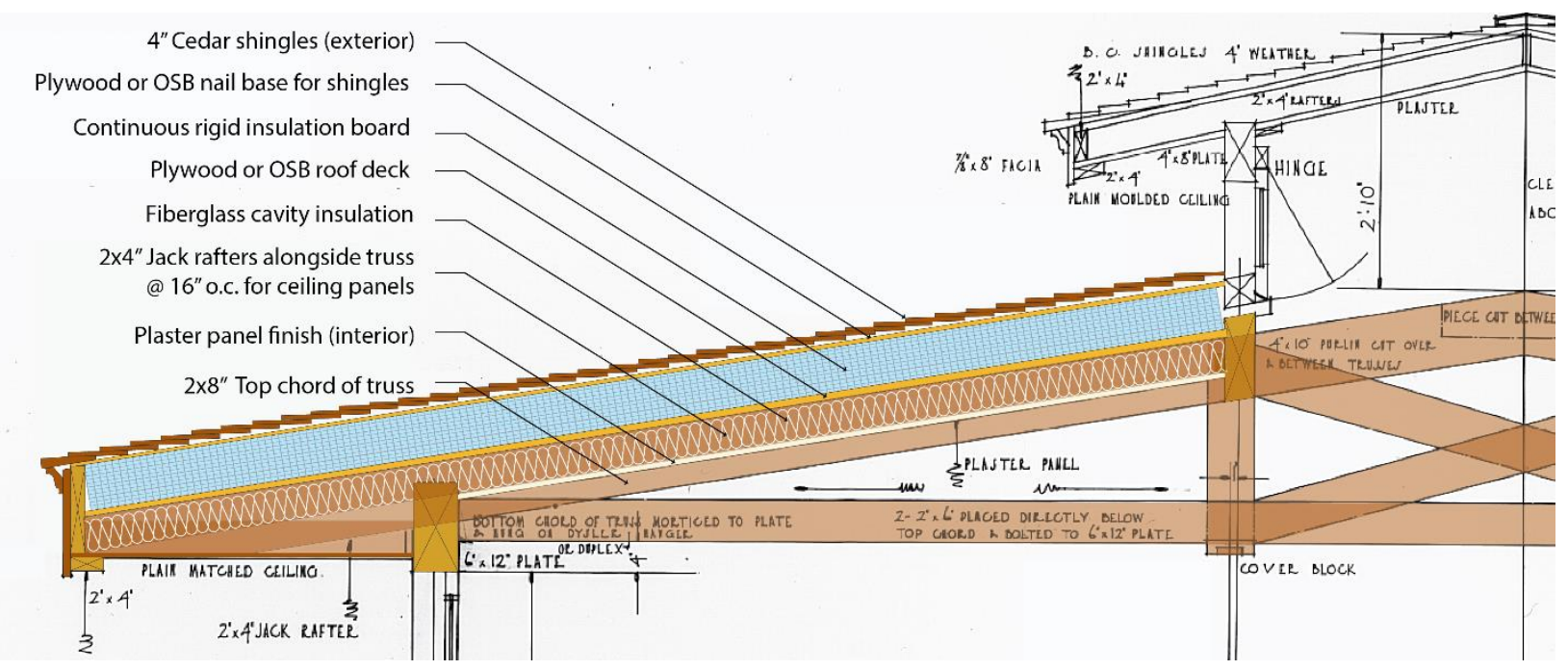

Figure 41 Compact unvented roof assembly using fiberglass cavity insulation and continuous rigid insulation above roof deck [69]. 


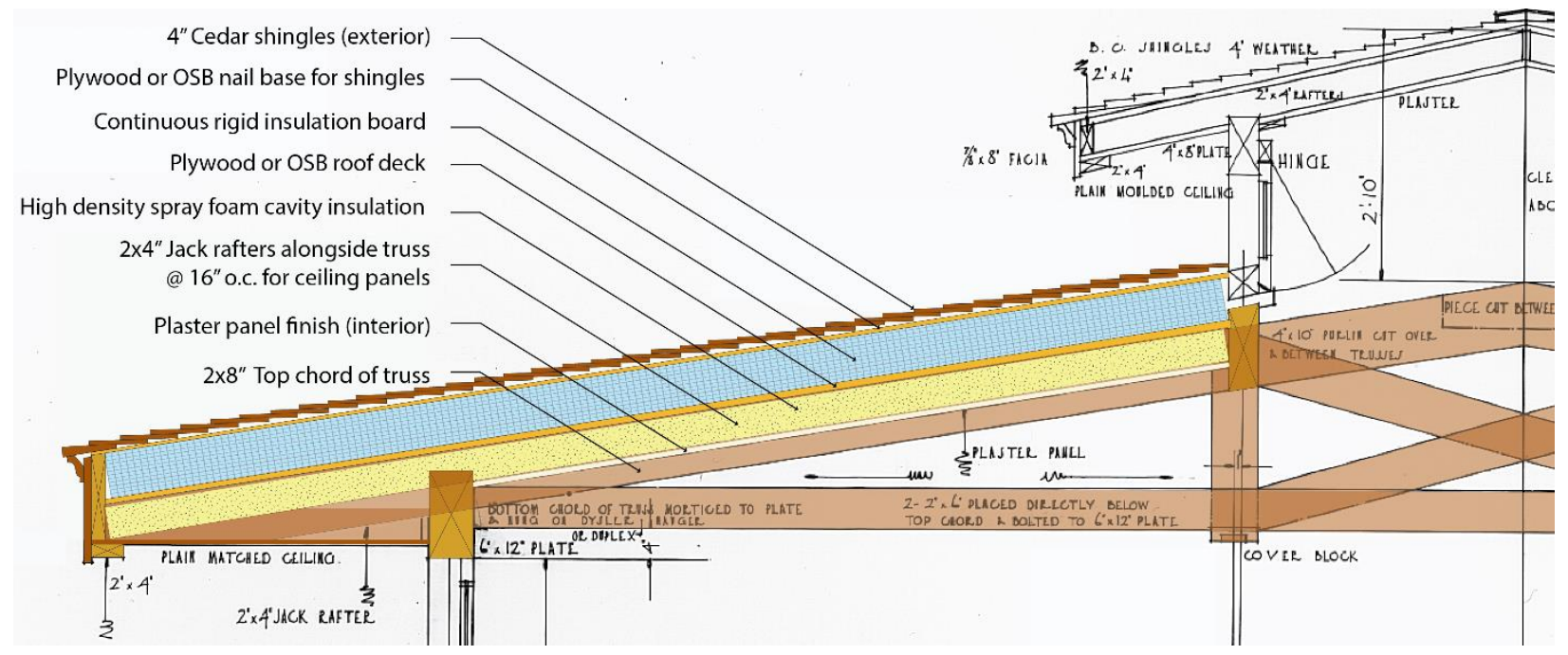

Figure 42 Compact unvented roof assembly using High density spray foam cavity insulation and continuous rigid insulation above roof deck [69].

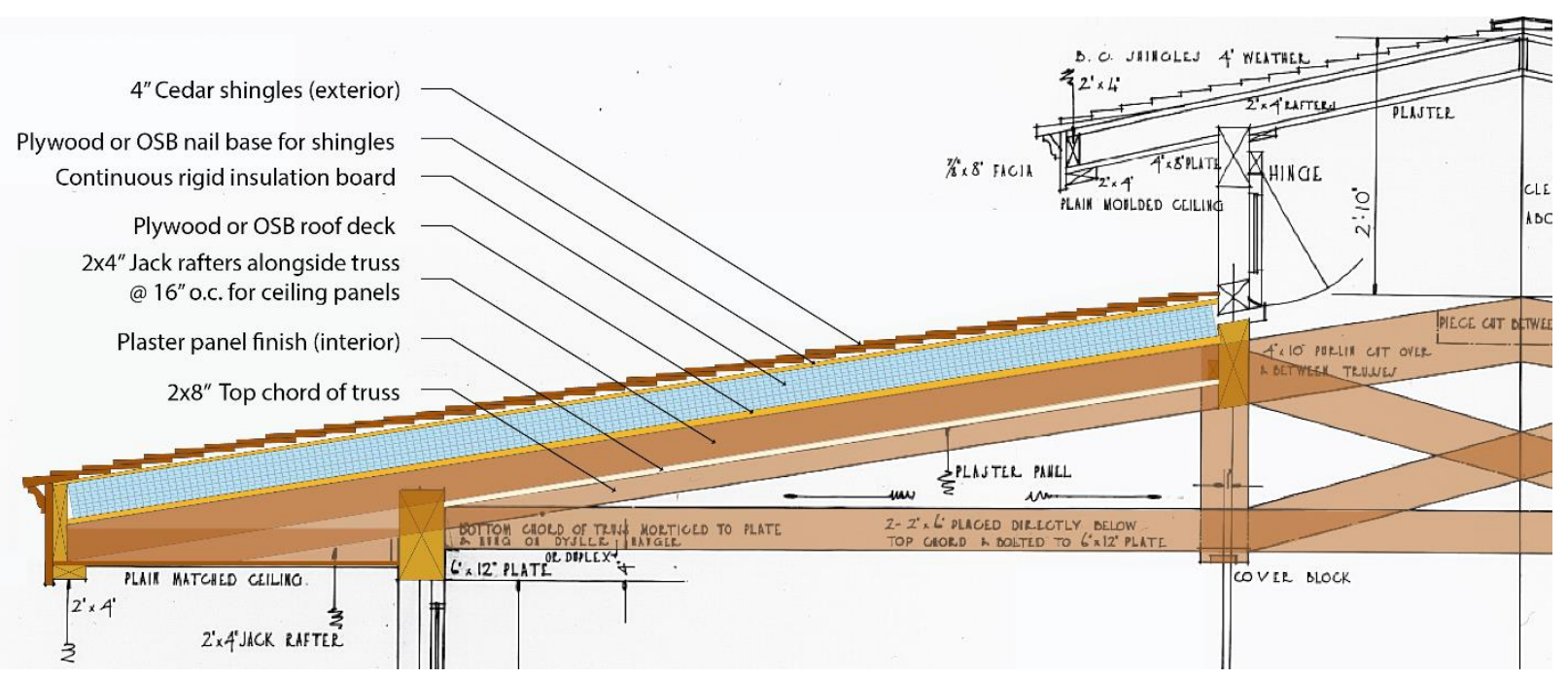

Figure 43 Compact unvented roof assembly with continuous rigid insulation entirely above roof deck [69]. 


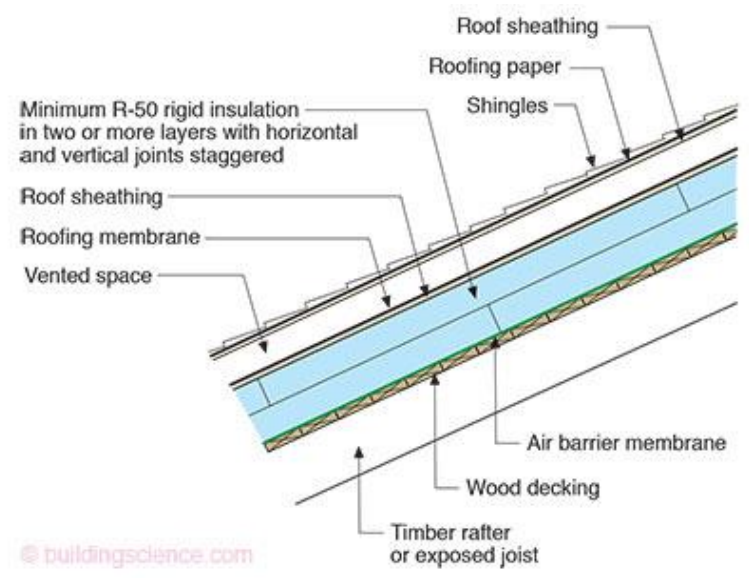

Figure 44 The unvented "under-roof" is topped with a vented "over-roof" to control ice-damming [70].

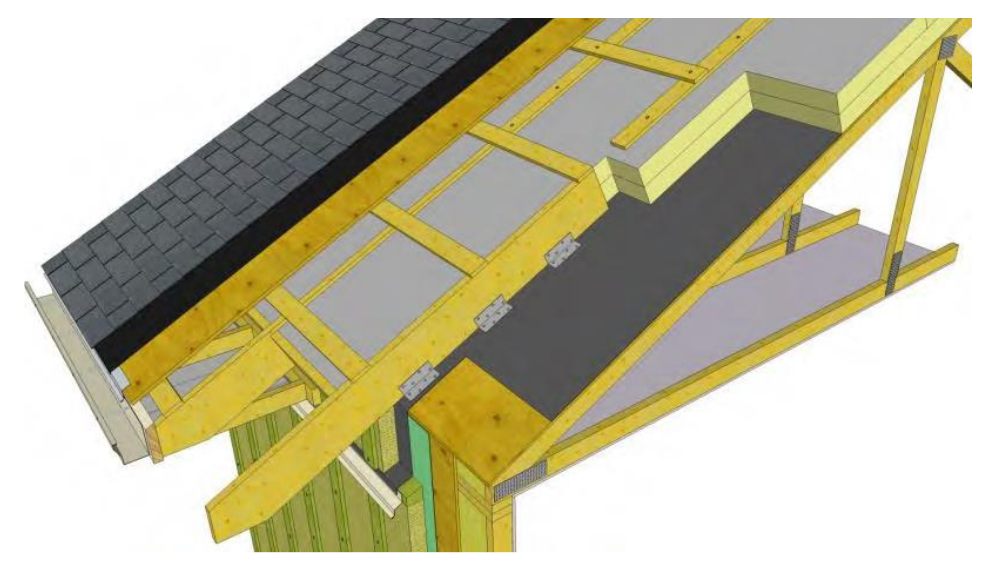

Figure 45 Pitched roof assembly with unvented "under-roof" is topped with a vented "over-roof" [62].

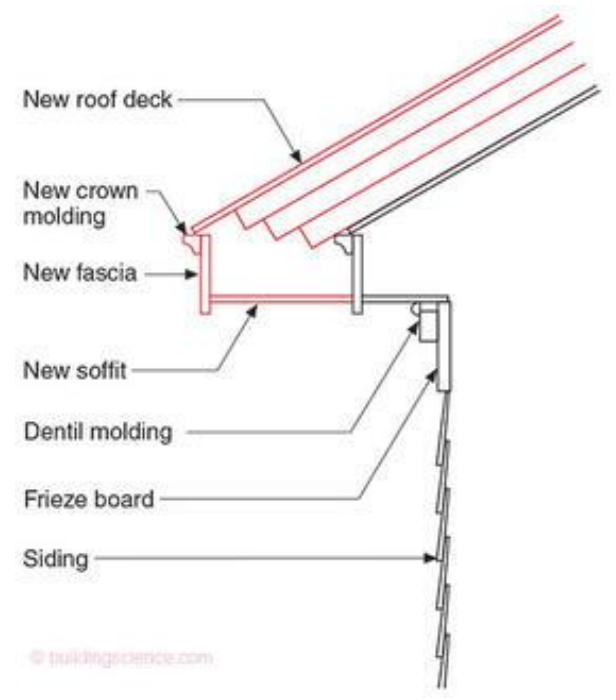

Figure 46 Pitched roof assembly showing the impact of the layers of insulation on the aesthetics of the roof edges [70]. 


\subsubsection{Addressing the CDE}

Since the control variables are the character-defining elements, this section discusses the impacted character-defining elements in the baseline prescriptive building design and how the building envelope need to be addressed in order to preserve the original character of the Banff Pavilion.

As described in section 11.1.3, the proportions and the shape of the building are two essential characters that define the prairie-style building design of FLW. On one side, adding one inch of additional insulation to the wall may be acceptable and not significantly intrusive for the CDE. However, the six-inch insulation addition to the roof assembly cannot be tolerated considering that the roofing system is distinguished by its flattened appearance which emphasises the horizontality of the whole building. Figure 46 shows how other aesthetic problems can arise when using above-deck insulation over a pitched roof.

\subsection{Building Envelope Trade-Off Option}

Based on the performance criteria set by the baseline design requirements, this section determines the proposed design of the assembly and openings for the walls and roof as stated in section 5.6 of ASHRAE 90.1. Also, Table 6 presents the minimum rated R-value for insulation and the maximum allowed assembly u-factor, which are determined by the procedure described in Appendix A of ASHRAE 90.1. In order to specify a proposed building design, all the elements that alter the original character are dismissed. It implies that the added insulation in the wall assembly (one inch of XPS) and in the roof assembly (six inches of polyisocyanurate) be removed to preserve the building shape and proportions. All other components stay the same for both buildings. Usually, when the proposed window to wall ratio is above $40 \%$, the baseline building would be limited to a maximum of $40 \%$. In this case, the window to wall ratio and the skylight to roof ratio were below the prescriptive requirement. Calculation of Baseline Envelope Performance Factor by Energy Modelling

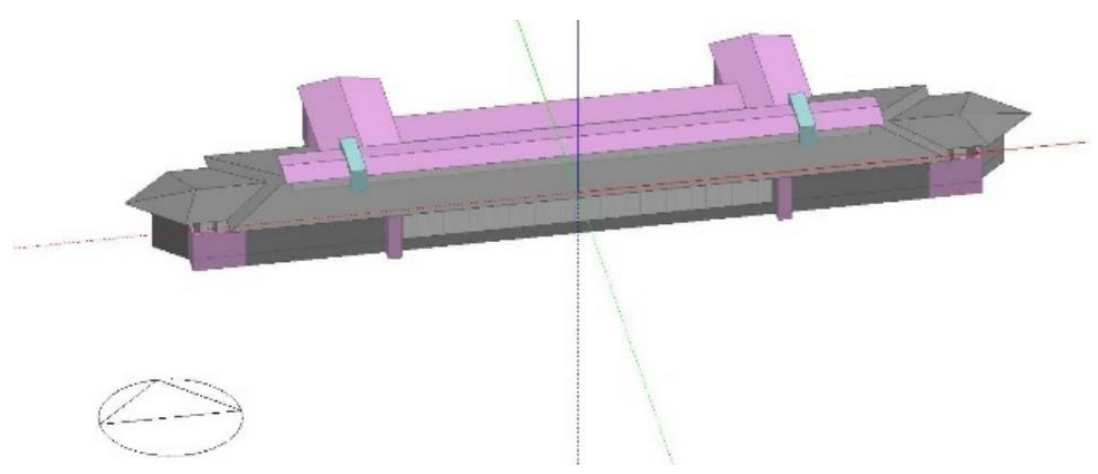

Figure 47 A 3D model of the Banff Pavilion original design which serves as trade-off proposed building. 


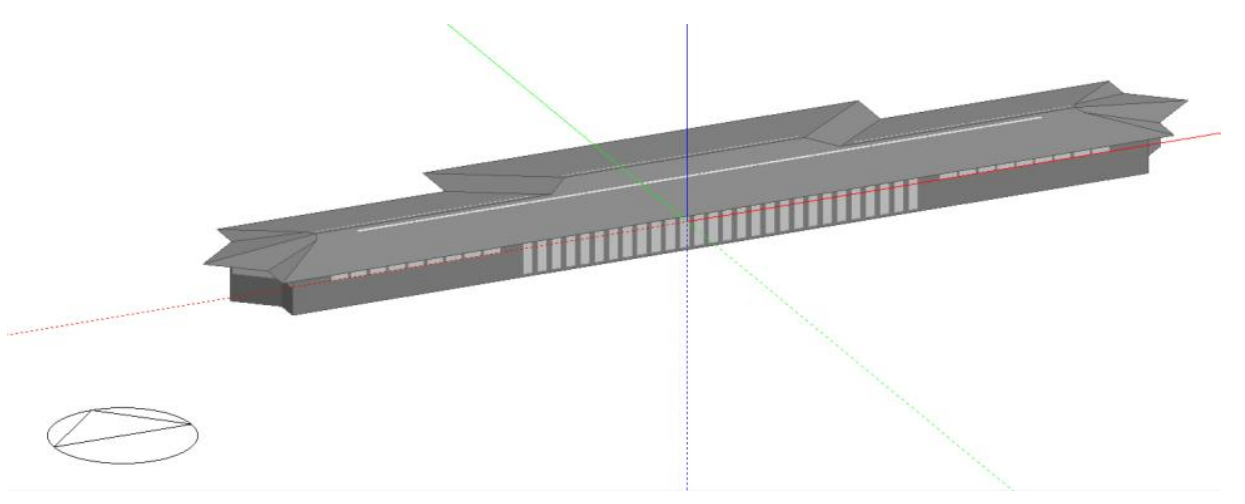

Figure 48 The 3D model of the Banff Pavilion original design after dimensions simplifications.

The following Table 5 to Table 11 present the properties of the energy model based on the original design plans and the minimum requirements of the Building Envelope section in ASHRAE 90.1

Table 5 Energy Model General Information.

\begin{tabular}{|c|c|}
\hline $\begin{array}{l}\text { Location of the building, including street address and climate } \\
\text { zone. }\end{array}$ & Near Sundance Rd, Banff, Alberta \\
\hline Coordinates (longitude, latitude) & $51.173348,-115.578210$ \\
\hline Location corresponding to the weather data used & Calgary, $A B$ \\
\hline Simulation program used to perform the simulation & $\begin{array}{l}\text { DesignBuilder (Energy+ } \\
\text { simulator) }\end{array}$ \\
\hline \multicolumn{2}{|l|}{ At the Building Level } \\
\hline Space conditioning category and building area type & Religious building \\
\hline Floor Area & $478.8 \mathrm{~m}^{2}\left(5153.45 \mathrm{ft}^{2}\right)$ \\
\hline \multicolumn{2}{|l|}{ At the Exterior Surface Level } \\
\hline Building envelope assembly type & wood-frame construction \\
\hline Gross area & $1634.6 \mathrm{~m}^{2}\left(17594.3 \mathrm{ft}^{2}\right)$ \\
\hline Orientation & $\begin{array}{l}\text { Horizontally in an East-West } \\
\text { direction }\end{array}$ \\
\hline Associated space-conditioning category & nonresidential conditioned space \\
\hline Building area type & Religious building \\
\hline
\end{tabular}


Table 6 3D Energy Modelling Information - Prescriptive Requirements based on Appendix A Rated values.

\begin{tabular}{|c|c|c|c|}
\hline & Roof & Above-Grade Walls & Floor \\
\hline & \multicolumn{3}{|c|}{ SI units (IP units) } \\
\hline Class of construction & Insulation Entirely Above Deck & Wood-framed walls & Wood-Joist Floor \\
\hline Opaque area & $807 \mathrm{~m}^{2}\left(8686.8 \mathrm{ft}^{2}\right)$ & $348.71 \mathrm{~m}^{2}\left(3753.48 \mathrm{ft}^{2}\right)$ & $478.8 \mathrm{~m}^{2}\left(5153.97 \mathrm{ft}^{2}\right)$ \\
\hline Assembly U-factor & $\begin{array}{c}0.16(0.028) \\
{[T A B L E \text { A2.2.3] }}\end{array}$ & $\begin{array}{c}0.27(0.047) \\
{[\text { TABLE A3.4.3.1] }}\end{array}$ & $\begin{array}{c}0.15(0.026) \\
{[\text { TABLE A5.4.3.1] }}\end{array}$ \\
\hline \multicolumn{4}{|l|}{ Heat Capacity } \\
\hline Insulation position & Entirely Above Deck & $\begin{array}{l}\text { Wood studs at } 600 \mathrm{~mm} \\
\text { (24 in), } 140 \mathrm{~mm} \text { (5.5 in) } \\
\text { deep wall cavities }\end{array}$ & $\begin{array}{c}\text { Wood joists } 286 \mathrm{~mm} \text { (11.25 } \\
\text { in) deep }\end{array}$ \\
\hline \multirow[t]{2}{*}{ Rated R-value } & R-6.2 c.i. (R-35) & $\begin{array}{l}\text { R-3.3 + R-0.9 c.i. } \\
\text { (R-19 + R-5 c.i.) }\end{array}$ & $\begin{array}{l}\text { Cavity filled R-6.7 (R-38) } \\
\text { with no c.i. }\end{array}$ \\
\hline & Skylights & Windows & Opaque Doors \\
\hline Width $x$ height $x$ depth & $\begin{array}{c}406 \times 310 \times 100 \mathrm{~mm} \\
(16 \times 12.24 \times 4 \mathrm{in})\end{array}$ & - & - \\
\hline Class of construction & $\begin{array}{c}\text { Double Glazing, } \mathrm{e}=0.40 \text { on } \\
\text { surface } 2 \text { or } 3 \text { with } \\
12.7 \mathrm{~mm}(0.5 \mathrm{in}) \text { airspace }\end{array}$ & $\begin{array}{l}\text { Vertical Double-Glazing } \\
\text { Fenestration }\end{array}$ & - \\
\hline Area & $19.6 \mathrm{~m}^{2}\left(211 \mathrm{ft}^{2}\right)$ & $154.4 \mathrm{~m}^{2}\left(1661.6 \mathrm{ft}^{2}\right)$ & - \\
\hline $\begin{array}{l}\text { Assembly U-factor in SI } \\
\text { units (IP units) }\end{array}$ & $4.39(0.77)$ & $3.4(0.60)$ & $3.4(0.6)$ \\
\hline SHGC & 0.62 & 0.59 & - \\
\hline Visible Transmittance & 0.63 & 0.64 & - \\
\hline Projection Factor & No external shades & No external shades & - \\
\hline
\end{tabular}


Table 7 Assembly properties of the modelled baseline wood-frame wall.

\begin{tabular}{|c|c|}
\hline \multicolumn{2}{|l|}{ Outermost layer } \\
\hline \&aterial & 0.75 in Siding(Wood, bevel, $9.8 \mathrm{in}$., lapped) \\
\hline Thickness (not used in thermal calcs) (in) & 0.750 \\
\hline \multicolumn{2}{|l|}{ Layer 2} \\
\hline Material & 6 in. depth cavity R-19 Insulation Mineral fiber (Effective framing/cavity R-value at 24 in. on center) \\
\hline Thickness (in) & 6.000 \\
\hline \multicolumn{2}{|l|}{$\square$ Bridged? } \\
\hline Material & 6 in. Wood, $2 \times 4$ at R-1.25/in. \\
\hline Percent bridging & 16 \\
\hline \multicolumn{2}{|l|}{ Layer 3} \\
\hline \&Material & XPS Extruded Polystyrene - HFC Blowing \\
\hline $\begin{array}{l}\text { Thickness (in) } \\
\square \text { Bridged? }\end{array}$ & 1 \\
\hline \multicolumn{2}{|l|}{ Innermost layer } \\
\hline$\&$ Material & $0.75 \mathrm{in} \mathrm{Siding(Wood,} \mathrm{bevel,} 9.8 \mathrm{in}$., lapped) \\
\hline Thickness (not used in thermal calcs) (in) & 0.750 \\
\hline
\end{tabular}

Table 8 Heat transfer properties of the modelled baseline wood-frame wall.

\begin{tabular}{|c|c|c|}
\hline Inner surface & & $\approx$ \\
\hline Convective heat transfer coefficient (Btu/h-ft2- $\left.{ }^{\circ} \mathrm{F}\right)$ & 0.492 & \\
\hline Radiative heat transfer coefficient (Btu/h-ft2- $\mathrm{F}$ ) & 0.976 & \\
\hline Surface resistance ( $\mathrm{ft} 2-\mathrm{F}-\mathrm{hr} / \mathrm{Btu})$ & 0.682 & \\
\hline Outer surface & & $\approx$ \\
\hline Convective heat transfer coefficient (Btu/h-ft2- $\left.{ }^{\circ} \mathrm{P}\right)$ & 4.895 & \\
\hline Radiative heat transfer coefficient (Btu/h-ft2- $\left.{ }^{\circ} \mathrm{F}\right)$ & 0.976 & \\
\hline Surface resistance ( $\mathrm{ft} 2-\mathrm{F}-\mathrm{hr} / \mathrm{Btu})$ & 0.170 & \\
\hline No Bridging & & $\approx$ \\
\hline U-Value surface to surface (Btu/h-ft2- $\left.{ }^{\circ} \mathrm{F}\right)$ & 0.032 & \\
\hline R-Value (tt2-F-hr/Btu) & 31.761 & \\
\hline U-Value (Btu/h-ft2-`F) & 0.032 & \\
\hline With Bridging (BS EN ISO 6946) & & 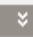 \\
\hline Thickness (in) & 8.500 & \\
\hline Km-Internal heat capacity (-) & 0.0000 & \\
\hline Upper resistance limit (ft2-F-hr/Btu) & 26.729 & \\
\hline Lower resistance limit (ft2-F-hr/Btu) & 24.901 & \\
\hline U-Value surface to surface $\left(B t u / h-f t 2-{ }^{\circ} \mathrm{F}\right)$ & 0.040 & \\
\hline R-Value (ft2-F-hr/Btu) & 25.815 & \\
\hline U-Value (Btu/h-ft2-`F) & 0.039 & \\
\hline
\end{tabular}

Table 9 Assembly properties of the modelled baseline roof.

\begin{tabular}{|c|c|}
\hline \multicolumn{2}{|l|}{ Outermost layer } \\
\hline SMaterial & $0.3 \mathrm{in}$. Shingles(Wood, plus ins. backer board) \\
\hline Thickness (not used in thermal calcs) (in) & 0.300 \\
\hline \multicolumn{2}{|l|}{ Layer 2} \\
\hline$\$$ Material & MRP Foam- polyisocyanate \\
\hline Thickness (in) & 6.000 \\
\hline \multicolumn{2}{|l|}{$\square$ Bridged? } \\
\hline \multicolumn{2}{|l|}{ Innermost layer } \\
\hline Material & Oriented strand board (OSB) \\
\hline Thickness (in) & 1.000 \\
\hline \multicolumn{2}{|l|}{$\square$ Bridged? } \\
\hline$\$$ Material & $8 \mathrm{in}$. Wood, $2 \times 4$ at R-1.25/in. \\
\hline Percent bridging & 20 \\
\hline
\end{tabular}

Table 10 Heat transfer properties of the modelled baseline roof. 


\begin{tabular}{|c|c|}
\hline \multicolumn{2}{|l|}{ Inner surface } \\
\hline Convective heat transfer coefficient $\left(\mathrm{Btu} / \mathrm{h}-\mathrm{ft} 2-^{\circ} \mathrm{F}\right)$ & 0.670 \\
\hline Radiative heat transfer coefficient (Btu/h-ft2- $\mathrm{F}$ ) & 0.976 \\
\hline Surface resistance (tt2-F-hr/Btu) & 0.608 \\
\hline \multicolumn{2}{|l|}{ Outer surface } \\
\hline Convective heat transfer coefficient $\left(\mathrm{Btu} / \mathrm{h}-\mathrm{ft} 2{ }^{\circ} \mathrm{P}\right)$ & 4.895 \\
\hline Radiative heat transfer coefficient (Btu/h-ft2- $\left.{ }^{*} \mathrm{~F}\right)$ & 0.976 \\
\hline Surface resistance (tt2-F-hr/Btu) & 0.170 \\
\hline \multicolumn{2}{|l|}{ No Bridging } \\
\hline U-Value surface to surface $\left(\mathrm{Btu} / \mathrm{h}-\mathrm{ft} 2 \mathrm{P}^{\circ} \mathrm{F}\right)$ & 0.024 \\
\hline R-Value (tt2-F-hr/Btu) & 42.342 \\
\hline U-Value (Btu/h-ft2-`F) & 0.024 \\
\hline \multicolumn{2}{|l|}{ With Bridging (BS EN ISO 6946) } \\
\hline Thickness (in) & 7.300 \\
\hline Km-Internal heat capacity $(-)$ & 33.0019 \\
\hline Upper resistance limit (ft2-F-hr/Btu) & 43.725 \\
\hline Lower resistance limit (tt2-F-hr/Btu) & 42.578 \\
\hline U-Value surface to surface $\left(\mathrm{Btu} / \mathrm{h}-\mathrm{ft} 2 \mathrm{P}^{\circ} \mathrm{F}\right)$ & 0.024 \\
\hline R-Value (tt2-F-hr/Btu) & 43.152 \\
\hline U-Value (Btu/h-ft2-`F) & 0.023 \\
\hline
\end{tabular}

Table 11 Modelled building window to wall area ratio and skylight to roof area ratio.

\begin{tabular}{|ll|}
\hline Proposed Building Vertical Window To Wall Area Ratio (WWR) \\
\hline Total gross wall area (ft2) & 3753.05 \\
Total window area (tt2) & 994.59 \\
\hline Total building window to wall area ratio (\%) & 26.50 \\
\hline \begin{tabular}{l} 
Window To Wall Area Ratio (WWR) For Each Elevation \\
\hline East elevation WWR (\%)
\end{tabular} & 12.85 \\
\hline South elevation WWR (\%) & 36.43 \\
\hline West elevation WWR (\%) & 11.57 \\
\hline North elevation WWR (\%) & 19.48 \\
\hline Proposed Building Skylight To Roof Area Ratio & \\
\hline Building skylight to roof area ratio (\%) & 4.12 \\
\hline Baseline Building Requirements & $\mathbf{2 6 . 5 0}$ \\
\hline Window to wall area ratio (\%) & $\mathbf{4 . 1 2}$ \\
\hline
\end{tabular}

\subsubsection{Proposed Building Design}

The proposed building design must incorporate the original Banff Pavilion CDEs with very little alteration.

The baseline building main added components are the continuous insulation in the wall and roof assemblies, the double glazing in the windows and skylights. The HVAC system is added to account for the heating and the cooling seasons, although the original Banff Pavilion was only functional during summer. Assuming the HVAC system can be completely hidden and unobtrusive, the other elements are modified to resemble the original Banff Pavilion design, as shown in Table 12. 
Table 12 Building envelope differences between the baseline building and the proposed building.

\begin{tabular}{|c|c|c|}
\hline & Baseline Building & Proposed Building \\
\hline & \multicolumn{2}{|c|}{ SI units (IP units) } \\
\hline \multicolumn{3}{|l|}{ Roofs } \\
\hline Insulation in 4 inches cavity & None & $\begin{array}{c}3.5 \text { in of sprayed PUR (R- } \\
17.5)\end{array}$ \\
\hline Insulation Entirely above Deck & R-6.2 c.i. (35 c.i.) & None \\
\hline Thickness of added continuous insulation & 6 in & None \\
\hline \multicolumn{3}{|l|}{ Walls, above Grade } \\
\hline Wood-frame $2 \times 6$ stud wall & $\begin{array}{l}\text { R-3.3 + R-0.9 c.i. } \\
(19+5 \text { c.i. })\end{array}$ & $\begin{array}{c}\text { R-3.3 (Fiberglass batt) } \\
\text { (R-19) }\end{array}$ \\
\hline Thickness of added continuous insulation & 1 in of XPS (R-5) & None \\
\hline \multicolumn{3}{|l|}{ Fenestration } \\
\hline Vertical Fenestration & $\begin{array}{l}\text { Double low-r (e2=.4) } \\
\text { clear } 3 \mathrm{~mm} / 13 \mathrm{~mm} \text { air }\end{array}$ & $\begin{array}{c}\text { Single low-r }(e 2=.4) \text { clear } \\
3 \mathrm{~mm}\end{array}$ \\
\hline U-value & $(0.402)$ & $(0.871)$ \\
\hline $0 \%-40 \%$ of Wall & $26.20 \%$ & $26.20 \%$ \\
\hline SHGC & 0.690 & 0.775 \\
\hline \multicolumn{3}{|l|}{ Skylight, $0 \%-3 \%$ of Roof } \\
\hline All types & ASHRAE 90.1 compliant & $\begin{array}{c}\text { Single low-r }(e 2=.4) \text { clear } \\
3 \mathrm{~mm}\end{array}$ \\
\hline U-value & $(0.60)$ & $(0.871)$ \\
\hline SHGC & 0.59 & 0.775 \\
\hline
\end{tabular}

\subsubsection{Simulation Results}

First, the results of the simulation (Figure 49) have shown that the Total Annual Energy Consumption of the baseline building is $284,615.53 \mathrm{kBtu}$ compared to $310,128.64 \mathrm{kBtu}$ for the proposed building, which represents a $9 \%$ difference that deems the proposed design not compliant. The Energy Per Total Building Area is at $45.09 \mathrm{kBtu} / \mathrm{ft}^{2}$ for the Proposed Building compared to $41.38 \mathrm{kBtu} / \mathrm{ft}^{2}$ for the baseline building. The missing insulation and the single glazing in the wall and roof assemblies for the proposed building explain the difference in performance. The next step is to upgrade the proposed building envelope design to compensate for the excess energy consumption compared to the baseline building. 


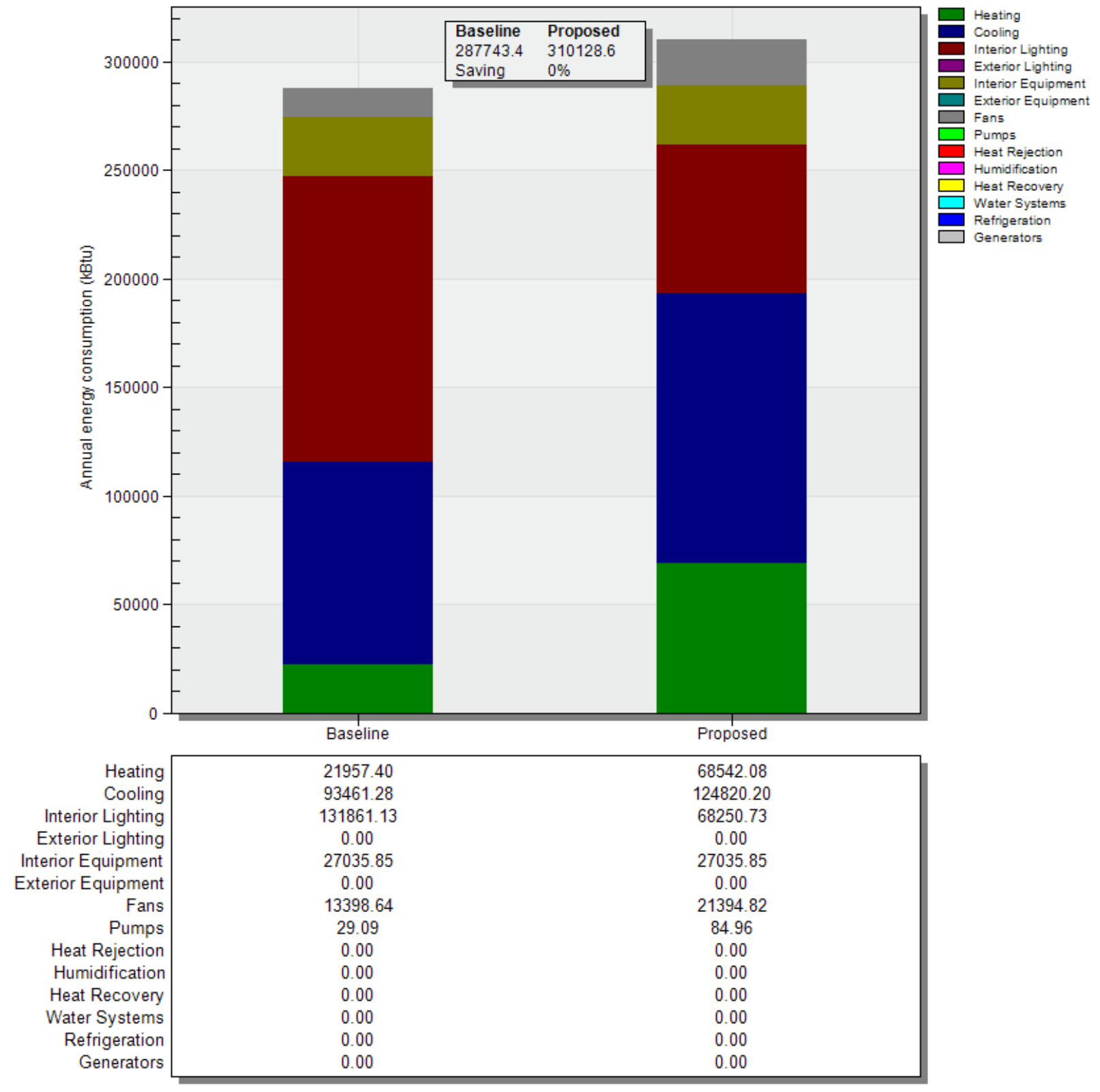

Figure 49 Energy consumption output for baseline and proposed building. 


\subsubsection{Envelope modification to the Proposed Design}

In order to preserve the character-defining elements, no added thickness can be incorporated in the original building envelope assemblies, except for the floors where the additional insulation thickness is not apparent. Acceptable solutions may involve incorporating double glazing windows and triple glazing skylights. Also, the use of better performing building envelope such as PUR cavity insulation or Structural Insulated Panels (SIPs) can achieve higher thermal resistance for the same cavity thickness. Therefore, a second simulation with upgrades to the proposed building envelope assembly is done in order to compensate for the loss of performance between the proposed and the baseline building design. Table 13 shows the differences in building envelope inputs into the second simulation. The upgrade considers the use of sprayed PUR for the walls and roof assemblies, which has a better thermal resistance per inch than the fiberglass batt. Also, the glazed areas are upgraded to triple glazing for the skylights and double glazing for the wall fenestration. The upgrade in glazing is assumed to be less intrusive to the CDEs than adding layers of insulation to the building assembly, which represents a fair compromise. The results of the second simulation are presented in Figure 50. The Total Annual Energy Consumption of the baseline building is $284,615.53 \mathrm{kBtu}$ compared to $291,113.4 \mathrm{kBtu}$ for the upgraded proposed building, which represents a $2 \%$ difference that deems the upgraded proposed design not compliant. The Energy Per Total Building Area is at $42.33 \mathrm{kBtu} / \mathrm{ft}^{2}$ for the Upgraded Proposed Building compared to $41.38 \mathrm{kBtu} / \mathrm{ft}^{2}$ for the baseline building. Although the upgraded has a better energy performance than the first proposed building simulation, the energy performance could not be compensated to achieve or surpass the baseline building performance. This simulation shows that the building envelope upgrades were efficient, and that compliance was almost achieved. 
Table 13 Building envelope differences between the baseline, proposed building, and the modified proposed building.

\begin{tabular}{|c|c|c|c|}
\hline & Baseline Building & Proposed Building & Upgraded Proposed Building \\
\hline & \multicolumn{3}{|c|}{ SI units (IP units) } \\
\hline \multicolumn{4}{|l|}{ Roofs } \\
\hline Insulation in 4 inches cavity & None & $\begin{array}{c}3.5 \text { in of sprayed } \\
\text { PUR (R-17.5) }\end{array}$ & $\begin{array}{c}3.5 \text { in of sprayed } \\
\text { PUR (R-17.5) }\end{array}$ \\
\hline Insulation Entirely above Deck & R-6.2 c.i. (R-35 c.i.) & None & None \\
\hline $\begin{array}{l}\text { Thickness of added } \\
\text { continuous insulation }\end{array}$ & 6 in & None & None \\
\hline \multicolumn{4}{|l|}{ Walls, above Grade } \\
\hline Wood-frame $2 \times 6$ stud wall & $\begin{array}{c}\text { R-3.3 (Fiberglass batt) } \\
\text { + R-0.9 c.i. (XPS) } \\
\text { (R-19 + R-5 c.i.) }\end{array}$ & $\begin{array}{c}\text { R-3.3 (Fiberglass } \\
\text { batt) } \\
\text { (R-19) }\end{array}$ & $\begin{array}{c}6 \text { in of sprayed } \\
\text { PUR (R-36) }\end{array}$ \\
\hline $\begin{array}{l}\text { Thickness of added } \\
\text { continuous insulation }\end{array}$ & 1 in & None & None \\
\hline \multicolumn{4}{|l|}{ Fenestration } \\
\hline Vertical Fenestration & $\begin{array}{l}\text { Double low-e }(\mathrm{e} 2=.4) \\
\text { clear } 3 \mathrm{~mm} / 13 \mathrm{~mm} \text { air }\end{array}$ & $\begin{array}{l}\text { Single low-e }(e 2=.4) \\
\text { clear } 3 \mathrm{~mm}\end{array}$ & $\begin{array}{c}\text { Double low-e }(\mathrm{e} 3=.1) \text { clear } \\
3 \mathrm{~mm} / 13 \mathrm{~mm} \text { arg }\end{array}$ \\
\hline U-value & $(0.402)$ & $(0.871)$ & $(0.267)$ \\
\hline $0 \%-40 \%$ of Wall & $26.20 \%$ & $26.20 \%$ & $26.20 \%$ \\
\hline SHGC & 0.690 & 0.775 & 0.647 \\
\hline \multicolumn{4}{|l|}{ Skylight, $0 \%-3 \%$ of Roof } \\
\hline All types & Double glazed & $\begin{array}{c}\text { Single low-e }(e 2=.4) \\
\text { clear } 3 \mathrm{~mm}\end{array}$ & $\begin{array}{c}\text { Triple glazed (e2=e5=0.1) Clear } \\
3 \mathrm{~mm} / 13 \mathrm{~mm} \text { argon }\end{array}$ \\
\hline U-value & $(0.60)$ & $(0.871)$ & $(0.138)$ \\
\hline SHGC & 0.59 & 0.775 & 0.47 \\
\hline
\end{tabular}




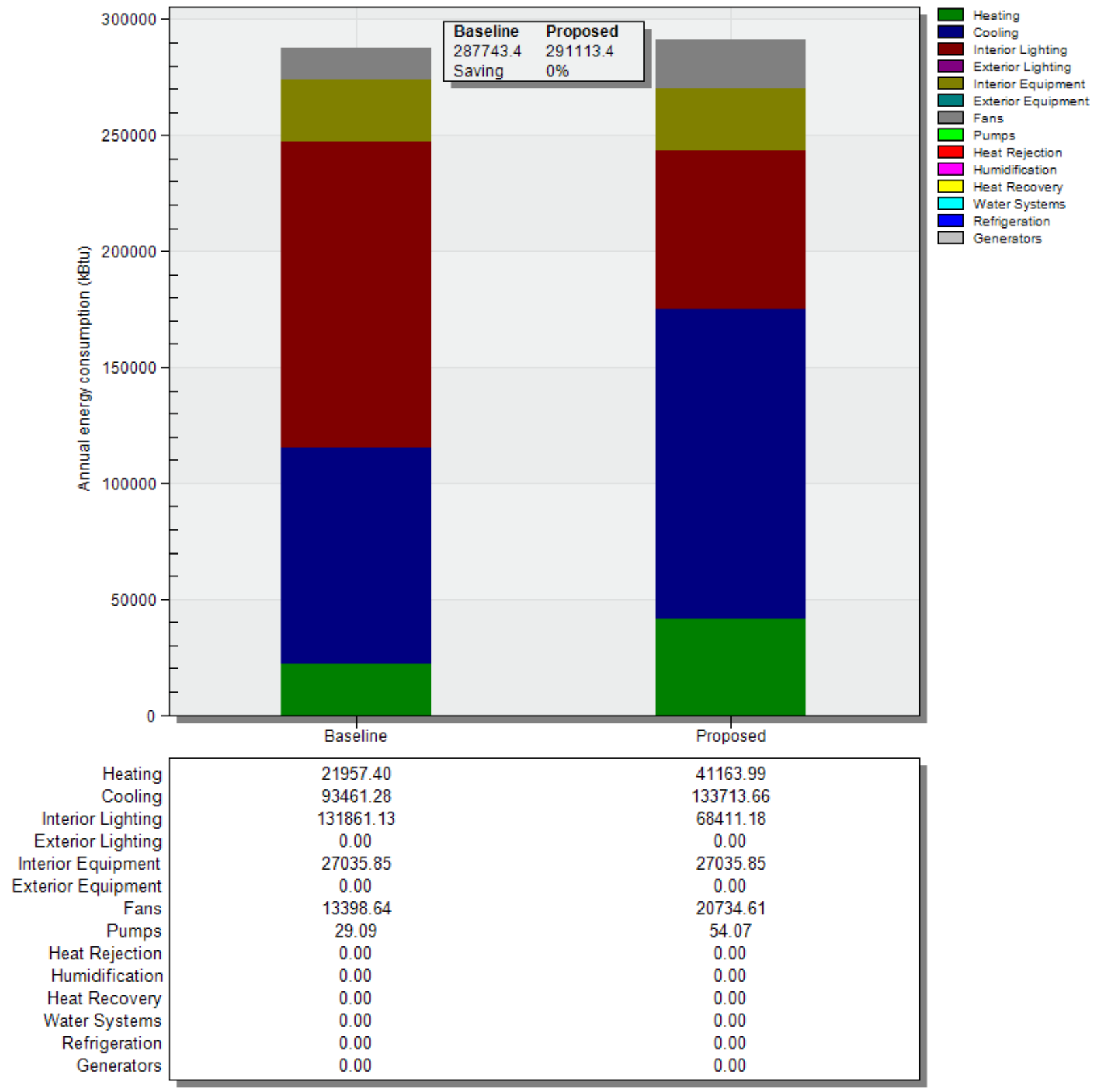

Figure 50 Energy consumption output for baseline and the upgraded proposed building. 


\subsection{Discussion over the Building Envelope Challenges}

The energy consumption simulation results affirm that, given the original design of the building envelope, the difference between the proposed building consumption and the baseline consumption is significant. The Building Envelope Trade-Off Method (BETM) is restricted to assembly solutions and glazing types. It is necessary to upgrade the proposed building envelope with features that do not alter the characterdefining elements (CDEs). However, these upgrades may not be sufficient to ensure compliance with the baseline performance requirement. Hence, the BETM is limited in options and has not proven its ability to preserve the heritage character while compensating for the energy performance lost in the envelope proposed design. Consequently, in order to preserve the CDEs without compromise, it will be necessary to compensate for the lack of performance of the building envelope by using other building systems, which means applying the Energy Cost Budget Method (ECM), as explained in section 11.2.4.2. Although more complex than the Building Envelope Trade-Off approach, the ECM provides more flexibility since all the building systems work simultaneously to achieve the baseline performance goals. This method is also practically convenient for the preservation of heritage character. The HVAC systems, for instance, can compensate for a significant energy load. From a constructional perspective, it is also possible to integrate the HVAC in a proposed building design without obstructing the architectural character by hiding its units and ducts in enclosed spaces and within assemblies.

Although out of the scope of this analysis, it is relevant to mention that the energy simulation software offers an optimized simulation involving performance objectives and variable parameters. In this case, the objective would be to minimize the energy consumption while the changeable variables represent the insulation in wall, roof and floor assemblies as well as the glazing type. The optimization will then choose the better building envelope trade-offs in order to meet the energy performance requirements. 


\section{PARTIAL CONCLUSION - PART 2}

The process of heritage building reconstruction is a challenging task for professionals who are willing to preserve the heritage aspects of a building while complying with current codes and standards. The first part of this study has shown the different reconstruction perspectives and approaches. It has shown that judgments about the heritage value cannot be universal or uniform, which means that no generic approach can be recognized world-widely since many cultural factors are involved. The first part however helped understanding how to approach the heritage value of a building from a qualitative perspective, which is effective at an early stage of the reconstruction process. The second part of this study helped evaluating the technical challenges of complying with codes and regulations by outlining a typical process of heritage building redesign and applying the process to the partial redesign of Frank Lloyd Wright's Banff Pavilion in Alberta.

First, one must assess the character-defining elements (CDEs) and their inherited value. Second, it is crucial to determine how the CDEs can be altered and by which specific parts of the Building Code. Third, it is essential to specify, through a constructional approach, which element within the requirements will be most restrictive and challenging. Finally, the study has demonstrated the process of complying with the Building Envelope section of the ASHRAE 90.1 standard. Among its compliance paths, the analysis determined the impacts of applying the prescriptive approach as well as the arising challenges of the Building Envelope Trade-Off option and its implications on the CDEs. It has shown that the building envelope trade-off option can be limited and may not provide an acceptable solution to the preservation of the heritage character, which eventually leads to adopting a more comprehensive compliance path such as the Energy Cost Budget Method. The use of more advanced software features such as optimized simulation can lead to more efficient trade-off scenarios.

Finally, the analysis was limited in scope and depth as it focused on one building element in a specific Building Code section. It only considered ASHRAE 90.1 requirements, whereas some supplementary standards such as SB-10 may apply under certain provinces law enforcement. Also, it has limited itself to the physical appearance of a building, without taking into account hidden characters or intangible aspects of heritage value. This study was restricted to the building science aspect of a building envelope, more investigation is needed in different areas of potential character-defining elements that could be found in buildings with heritage significance. Interestingly, there are sections of the Building Code where alternative compliance has to be demonstrated by a case by case evaluation, which leads to an indefinite number of paths and solutions. 


\section{Preserving a landmark}

The Farnsworth House, designed by Ludwig Mies van der Rohe, has suffered from multiple floods over the years because of its location in a high-risk flood zone. Its owner, a preservationist group, is considering three options to protect the house.
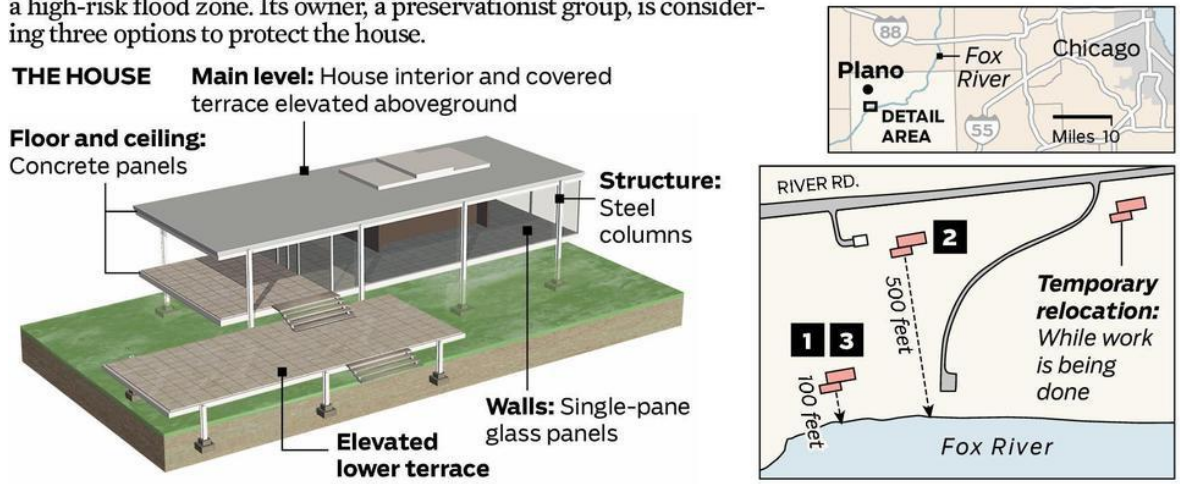

\section{OPTION 1: ELEVATE HOUSE IN PLACE}

Jack up house and demolish foundation. Temporarily move house. Add 9 feet of landfill above flood level. Set down building on new foundation.

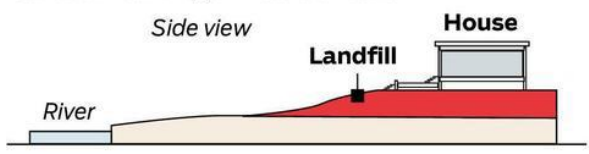

\section{OPTION 2: MOVE THE HOUSE}

Lift house from foundation and transport 400 feet north to a regraded area above flood level. Set down on new foundation with new utilities.

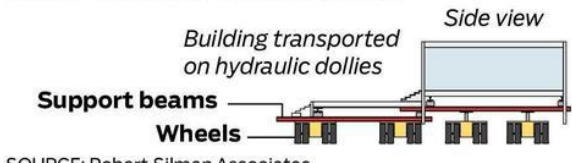

\section{OPTION 3: INSTALL LIFTING SYSTEM}

Temporarily move house and remove existing foundation. Integrate a permanent

hydraulic-and-steel-truss lift system into a concrete pit attached to a new foundation. The system would mechanically raise the house above flood lines prior to or during flooding.

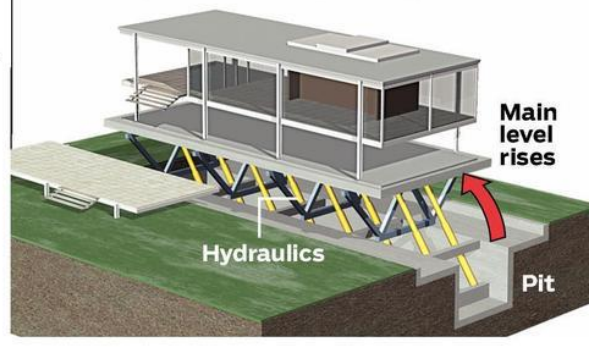

PHIL GEIB AND RICK TUMA/TRIBUNE

Figure A- 1 Floodproofing scenarios considered for the Farnsworth House in Chicago [71].

Table A- 1 Building envelope assembly minimum effective R-value by climate zone and heating degree day (HDD), as required by the 2011 National Energy Code for Buildings [62].

\begin{tabular}{|l|c|c|}
\hline Climate Zone and HDD $\left({ }^{\circ} \mathbf{C}\right)$ & Wood-frame, above-grade wall & Wood-frame roof, flat or sloped: \\
\hline Zone 4: $\mathbf{3 0 0 0}$ HDD & [R-value (RSI)] & 25.0 \\
& 18.0 & $(4.41)$ \\
\hline Zone 5: 3000 to 3999 HDD & $(3.17)$ & 31.0 \\
\hline Zone 6: $\mathbf{4 0 0 0}$ to 4999 HDD & 20.4 & $(5.46)$ \\
\hline Zone 7a: $\mathbf{5 0 0 0}$ to 5999 HDD & $(3.60)$ & 31.0 \\
& 23.0 & $(5.46)$ \\
\hline Zone 7b: $\mathbf{6 0 0 0}$ to 6999 HDD & $(4.05)$ & 35.0 \\
\hline Zone 8: $>$ 7000 HDD & 27.0 & $(6.17)$ \\
\hline
\end{tabular}


Table A- 2 High performance wood-frame building envelopes with effective R-value targets for compliance with energy standards [62].

\begin{tabular}{|c|c|c|c|}
\hline \multirow[b]{2}{*}{ Climate Zones } & Wood-frame, above-grade wall & $\begin{array}{l}\text { Wood-frame roof-insulation } \\
\text { entirely above deck: }\end{array}$ & $\begin{array}{l}\text { Wood-frame roof-attic and } \\
\text { other: }\end{array}$ \\
\hline & [R-value (RSI)] & [R-value (RSI)] & [R-value (RSI)] \\
\hline $\begin{array}{l}\text { Zones } 1 \text { to } 3 \text { : hot, } \\
\text { cooling dominated }\end{array}$ & $\begin{array}{l}\text { R-16 to R-22 } \\
\text { (2.8 to } 3.9 \text { ) }\end{array}$ & $\begin{array}{l}\mathrm{R}-25 \text { to } \mathrm{R}-30 \\
\text { (4.4 to } 5.3)\end{array}$ & $\begin{array}{l}\text { R-40 to } \mathrm{R}-50 \\
\text { (7.0 to } 8.8 \text { ) }\end{array}$ \\
\hline $\begin{array}{l}\text { Zones } 4 \text { to } 5 \text { : } \\
\text { mixed, heating } \\
\text { and cooling }\end{array}$ & $\begin{array}{c}\text { R-22 to R-28 } \\
\text { (3.9 to } 4.9 \text { ) }\end{array}$ & $\begin{array}{c}\text { R-30 to R-40 } \\
(5.3 \text { to } 7.0)\end{array}$ & $\begin{array}{l}\text { R-50 to R-60 } \\
\text { (8.8 to } 10.6 \text { ) }\end{array}$ \\
\hline $\begin{array}{l}\text { Zones } 6 \text { to } 8 \text { : cold, } \\
\text { heating } \\
\text { dominated }\end{array}$ & $\begin{array}{c}\mathrm{R}-28 \text { to } \mathrm{R}-40 \\
(4.9 \text { to } 7.0)\end{array}$ & $\begin{array}{c}\mathrm{R}-40 \text { to } \mathrm{R}-50 \\
(7.0 \text { to } 8.8)\end{array}$ & $\begin{array}{l}\text { R-60 to R-80 } \\
\text { (10.6 to } 14.1 \text { ) }\end{array}$ \\
\hline
\end{tabular}

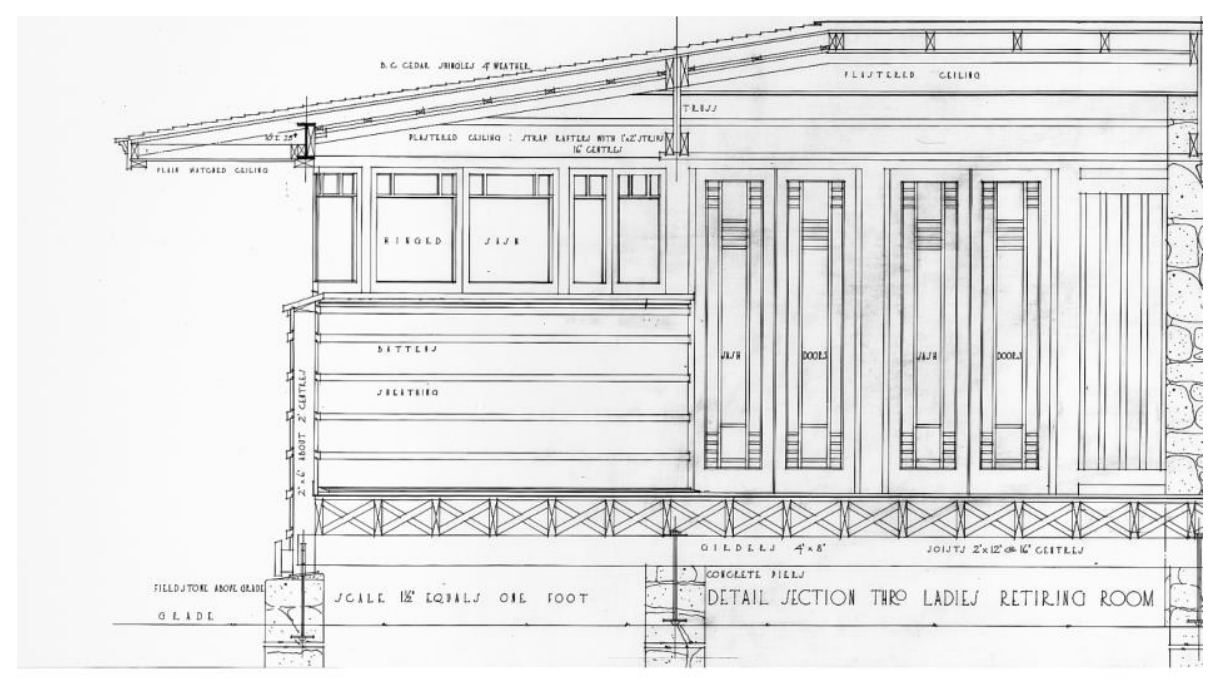

Figure A- 2 Original section drawing of the Banff Pavilion in an east-west axis [49].

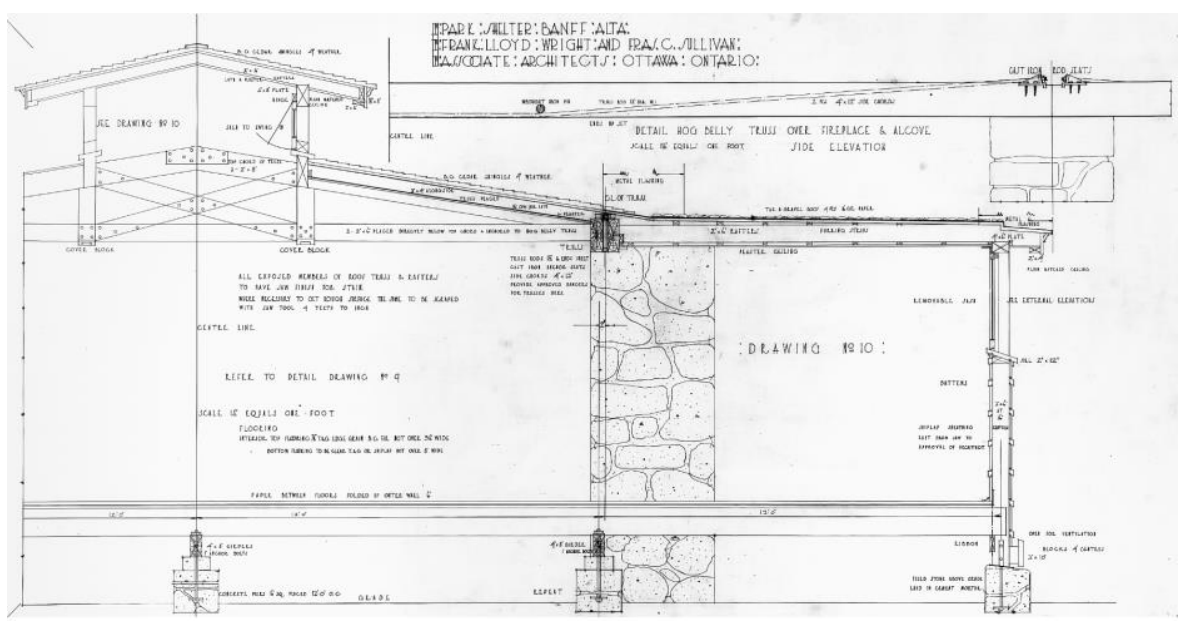

Figure A- 3 Original section drawing of the Banff Pavilion in a north-south axis [49]. 


\section{APPENDIX B}

\section{B1 Compliance with Part 3 - Fire Protection, Occupant Safety and Accessibility}

As it states in its Functional Statement, one aim of the Building Code is to "retard the effects of fire on facilities for notification, suppression and emergency response" [72]. Consequently, it requires that a building be of non combustible construction if occupants could encounter unprevented distress when evacuating the building in case of a fire [73]. Hence, non combustible construction is required for buildings exceeding a certain height or area [73]. In this study, it is assumed that combustible construction is permitted since the studied building is only one storey in building height with no basement and has a building area not more than $2400 \mathrm{~m}^{2}$. Also, in order to preserve the main character of the building, using wood frame construction is an essential and obvious aspect.

Table B- 1 Compliance with Part 3 - Fire Protection, Occupant Safety and Accessibility

\begin{tabular}{|c|c|c|c|c|}
\hline $\begin{array}{l}\text { Character- } \\
\text { defining } \\
\text { element (CDE) }\end{array}$ & $\begin{array}{l}\text { Code section reference in Acceptable } \\
\text { Solutions of Division B }\end{array}$ & Implications affecting the character & Impact and challenges & $\begin{array}{l}\text { Code alternative compliance } \\
\text { path }\end{array}$ \\
\hline $\begin{array}{l}\text { CDE 3.1 Site } \\
\text { Location and } \\
\text { Building } \\
\text { Orientation }\end{array}$ & $\begin{array}{l}\text { 3.1.1.3. Building constructed on Flood Plains } \\
\text { shall: } \\
\text { withstand anticipated vertical and } \\
\text { horizontal hydrostatic pressures acting on } \\
\text { the structure } \\
\text { incorporate floodproofing measures that } \\
\text { will preserve the integrity of exits and } \\
\text { means of egress }\end{array}$ & $\begin{array}{l}\text { Requires the exits to be designed as } \\
\text { flood proof which would either } \\
\text { require an elevate the ground in the } \\
\text { entrance/exit stairs height. It may also } \\
\text { require floodgates placed at the } \\
\text { entrances/exits. } \\
\text { Option 1: Elevate the ground level by } \\
\text { adding landfill. } \\
\text { Option 2: Relocating the building to a } \\
\text { Option 3: Install a hydraulic } \\
\text { foundation mechanism. } \\
\text { (See Figure A- 1) }\end{array}$ & $\begin{array}{l}\text { The proportions play an essential role in the so } \\
\text { called "horizontality" of the building that is a main } \\
\text { character-defining element in FLW prairie style } \\
\text { design. Any design that would change the } \\
\text { horizontal shape of the building or the horizontal } \\
\text { aspect of the site itself would go against the } \\
\text { architect's intent and philosophy. Hence, option } 1 \text { is } \\
\text { not a viable solution. } \\
\text { The site location is essential both for the view that } \\
\text { the occupants get from the surrounding but also for } \\
\text { its function as a shelter. Its proximity to the Bow } \\
\text { River is also required where occupants enjoy the } \\
\text { Banff Park activities such as canoeing. Another } \\
\text { aspect is its proximity to the bridge crossing the } \\
\text { Bow River on Banff Ave, which provides accessibility } \\
\text { to the building. Hence, option } 2 \text { is not a viable } \\
\text { solution. } \\
\text { As extravagant as option } 3 \text { is, it may be a great } \\
\text { engineering challenges, but it is an option that } \\
\text { preserves the building in case of flood. This option } \\
\text { affects the floor structural design as it needs } \\
\text { stiffness to withhold lifting. }\end{array}$ & $\begin{array}{l}\text { Incorporate a hydraulic } \\
\text { mechanism for foundations } \\
\text { that lifts itself that would uplift } \\
\text { the whole structure and } \\
\text { provide both protection of the } \\
\text { building entrances and the } \\
\text { wood structure and assembly } \\
\text { components. }\end{array}$ \\
\hline $\begin{array}{l}\text { CDE } 3.2 \\
\text { Building Shape } \\
\text { and Elevation }\end{array}$ & N/A & N/A & $\mathrm{N} / \mathrm{A}$ & N/A \\
\hline
\end{tabular}


Table B- 1 Compliance with Part 3 - Fire Protection, Occupant Safety and Accessibility (Continued)

\begin{tabular}{|c|c|c|c|c|}
\hline $\begin{array}{l}\text { CDE } 3.3 \text { Building } \\
\text { Layout and } \\
\text { Spaces }\end{array}$ & $\begin{array}{l}\text { 3.3.1.5. Egress Doorways } \\
\text { According to Table 3.3.1.5.A., two egress } \\
\text { doorways are required if the building is not } \\
\text { sprinkled and where the travel distance within } \\
\text { the room to the nearest egress doorway is } \\
\text { more } 15 \mathrm{~m} \text {. }\end{array}$ & $\begin{array}{l}\text { It may be required to add an egress } \\
\text { doorway. }\end{array}$ & $\begin{array}{l}\text { Since the layout is something that is crucial to the } \\
\text { design and doors cannot be moved or added. Also, an } \\
\text { alternative path to preserve the layout would be by } \\
\text { decreasing the areas of some spaces in order to comply } \\
\text { with the travel distance maximum value, but this path } \\
\text { will affect the proportions and hence is not permissible. }\end{array}$ & N/A \\
\hline $\begin{array}{l}\text { CDE } 3.4 \\
\text { Proportions }\end{array}$ & Refer to Table B- 2. & N/A & N/A & N/A \\
\hline $\begin{array}{l}\text { CDE } 3.5 \\
\text { Connection to } \\
\text { Outdoor }\end{array}$ & $\mathrm{N} / \mathrm{A}$ & N/A & N/A & N/A \\
\hline $\begin{array}{l}\text { CDE } 3.6 \\
\text { Materials } \\
\text { (wood, stone, } \\
\text { glass, concrete) }\end{array}$ & $\begin{array}{l}\text { 3.1.4. Combustible Construction } \\
\text { 3.1.4.5. Fire-Retardant Treated Wood Requires } \\
\text { a fire- resistance rating not less than } 45 \mathrm{~min} \text {. }\end{array}$ & Installing a sprinklers system. & $\begin{array}{l}\text { The sprinkler system pipework would need to be non- } \\
\text { apparent. The sprinklers heads would still be visible. }\end{array}$ & Division C Art. 1.3.2 \\
\hline $\begin{array}{l}\text { CDE } 3.7 \text { Roofing } \\
\text { (structure, } \\
\text { assembly) }\end{array}$ & $\begin{array}{l}\text { 3.2.2.16. Heavy Timber Roof Permitted } \\
\text { (1) a roof assembly is permitted to be of heavy } \\
\text { timber construction if the building is } \\
\text { sprinklered. } \\
\text { (2) Structural members permitted to be of } \\
\text { heavy timber construction. } \\
\text { 3.1.4.7. Heavy Timber Construction } \\
\text { 1. Minimum dimensions of wood elements } \\
\text { should comply with Table 3.1.4.7. Item } 1 . \\
\text { Column 3. The minimum dimensions for solid } \\
\text { sawn elements for beams, girders and trusses } \\
\text { are } 89 \mathrm{~mm} \text { width by } 140 \mathrm{~mm} \text { depth. } \\
\text { 2. The splice plates used on roof trusses in } \\
\text { heavy timber construction should be not less } \\
\text { than } 64 \mathrm{~mm} \text { thick. }\end{array}$ & $\begin{array}{l}\text { The original design of the roof truss } \\
\text { uses two sides of } 50.8 \times 152.4 \mathrm{~mm} \\
\text { ( } 2 \times 6 \text { in) for the bottom chord and } \\
50.8 \times 203.2 \mathrm{~mm}(2 \times 8 \mathrm{in}) \text { for the top } \\
\text { chord as well as } 50.8 \times 101.6 \mathrm{~mm} \\
\text { ( } 2 \times 4 \text { in) for the intersection webs. } \\
\text { The minimum dimension required } \\
\text { by the code is larger than the } \\
\text { original design, which means all } \\
\text { wood trusses members would } \\
\text { need to be thicker. (See Figure } 29)\end{array}$ & $\begin{array}{l}\text { Having thicker wood members would affect the interior } \\
\text { spaces and make it look narrow. As seen in the RFTC } \\
\text { building, FLW is said to have intentionally drawn optical } \\
\text { illusions on the roof trusses that would make the space } \\
\text { appear wider. }\end{array}$ & $\begin{array}{l}\text { An alternative solution } \\
\text { that implies another } \\
\text { issue: } \\
\text { 3.1.4.7.(12) The roof } \\
\text { truss is permitted to be } \\
\text { not less than } 64 \mathrm{~mm} \text { wide } \\
\text { if : } \\
\text { (a) the trusses are spaced } \\
\text { and blocked by a } \\
\text { continuous plate of } 38 \\
\text { mm secured to the } \\
\text { underside of the } \\
\text { members. } \\
\text { (b) the space is sprinkled. } \\
\text { (implies another issue) }\end{array}$ \\
\hline CDE 3.8 Ceiling & $\begin{array}{l}\text { 3.1.5.2. Minor Combustible Components } \\
\text { (1) (a) paint is a minor combustible component } \\
\text { that is permitted for a building required to be } \\
\text { of noncombustible construction. }\end{array}$ & $\begin{array}{l}\text { The interior look of the ceiling will } \\
\text { not be affected. }\end{array}$ & N/A & N/A \\
\hline
\end{tabular}




\section{Table B- 1 Compliance with Part 3 - Fire Protection, Occupant Safety and Accessibility (Continued)}

\begin{tabular}{|c|c|c|c|c|}
\hline $\begin{array}{l}\text { CDE } 3.9 \\
\text { Chimneys and } \\
\text { Fireplaces }\end{array}$ & $\mathrm{N} / \mathrm{A}$ & $\mathrm{N} / \mathrm{A}$ & $\mathrm{N} / \mathrm{A}$ & $\mathrm{N} / \mathrm{A}$ \\
\hline $\begin{array}{l}\text { CDE } 3.10 \\
\text { Mechanical and } \\
\text { electrical } \\
\text { equipment }\end{array}$ & N/A & N/A & N/A & N/A \\
\hline CDE 3.11 Lighting & $\begin{array}{l}\text { 3.1.13.2: Light diffusers and lenses should } \\
\text { have a maximum flame spread rating of } 150 \\
\text { for a sprinkled space and } 75 \text { for a non- } \\
\text { sprinkled space. }\end{array}$ & May affect the original lighting sets. & Forbids the use of plastic lenses or light diffusers. & N/A \\
\hline $\begin{array}{l}\text { CDE 3.12 Natural } \\
\text { Ventilation }\end{array}$ & N/A & $\mathrm{N} / \mathrm{A}$ & $\mathrm{N} / \mathrm{A}$ & $\mathrm{N} / \mathrm{A}$ \\
\hline $\begin{array}{l}\text { CDE } 3.13 \\
\text { Windows and } \\
\text { Openings } \\
\text { (including the } \\
\text { clerestory) }\end{array}$ & N/A & $\mathrm{N} / \mathrm{A}$ & N/A & $\mathrm{N} / \mathrm{A}$ \\
\hline $\begin{array}{l}\text { CDE 3.14 Fire } \\
\text { Safety Systems }\end{array}$ & $\begin{array}{l}\text { 3.2.2.27. Group A, Division 2, up to } 2 \text { Storeys, } \\
\text { Sprinklered } \\
\text { (1) A building classified as Group A, Division } 2 \\
\text { is permitted to be of combustible } \\
\text { construction or noncombustible construction } \\
\text { used singly or in combination, provided, } \\
\text { (a) except as permitted by Sentence } \\
\text { 3.2.2.7.(1), the building is sprinklered, } \\
\text { 3.2.2.23. Group A, Division 2, Any Height, Any } \\
\text { Area, Sprinklered } \\
\text { 3.2.2.28. Group A, Division 2, } 1 \text { Storey } \\
\text { (1) A building classified as Group A, Division } 2 \\
\text { is permitted to be of combustible } \\
\text { construction or noncombustible construction } \\
\text { used singly or in combination }\end{array}$ & Effects of item CDE 3.6. & Effects of item CDE 3.6. & $\begin{array}{l}\text { Effects of item CDE } \\
\text { 3.6. }\end{array}$ \\
\hline
\end{tabular}

Note: The need of fire, smoke, and heat detectors, manual pull stations portable fire extinguishers connected to a fire alarm system under 3.2.4.11, 3.2.4.12,3.2.4.18 and 3.2.5.17. Also, under 3.2.4.21, visual alert and alarm signals are required in some spaces of the building. Although quite small, these fixtures can greatly affect the feeling and interior look of a space especially that they are designed to be as much obstructive as possible in order to be easily located. 


\section{B2 Compliance with Part 5 - Environmental Separation}

Table B- 2 Compliance with Part 5 - Environmental Separation

\begin{tabular}{|c|c|c|c|c|}
\hline $\begin{array}{l}\text { Character- } \\
\text { defining } \\
\text { element (CDE) }\end{array}$ & Code section reference in Acceptable Solutions of Division B & $\begin{array}{l}\text { Implications affecting the } \\
\text { character }\end{array}$ & $\begin{array}{l}\text { Impact and } \\
\text { challenges }\end{array}$ & $\begin{array}{l}\text { Code alternative compliance } \\
\text { path }\end{array}$ \\
\hline $\begin{array}{l}\text { CDE 5.1 Site } \\
\text { Location and } \\
\text { Building } \\
\text { Orientation }\end{array}$ & $\begin{array}{l}\text { 5.7.1. Protection from Surface Water } \\
\text { 5.7.1.1. Prevention of Accumulation and Ingress } \\
\text { (1) Except as provided in Sentence (3), the building } \\
\text { shall be located, the building site shall be graded or catch basins shall be installed } \\
\text { so that surface water will not accumulate against the building. } \\
\text { (2) Except as provided in Sentence (3), the foundation walls shall be constructed } \\
\text { so that surface water will not, } \\
\text { (a) enter the building, or } \\
\text { (b) damage moisture susceptible materials. }\end{array}$ & Refer to Table B- 1. & Refer to Table B- 1. & Refer to Table B- 1. \\
\hline $\begin{array}{l}\text { CDE } 5.2 \\
\text { Building Shape } \\
\text { and Elevation }\end{array}$ & N/A & N/A & N/A & N/A \\
\hline $\begin{array}{l}\text { CDE } 5.3 \\
\text { Building Layout } \\
\text { and Spaces }\end{array}$ & N/A & N/A & N/A & N/A \\
\hline $\begin{array}{l}\text { CDE } 5.4 \\
\text { Proportions }\end{array}$ & $\begin{array}{l}\text { 5.3.1.2. Properties to Resist Heat Transfer } \\
\text { (1) Materials and components installed to provide the required resistance to heat } \\
\text { transfer or the means implemented to dissipate heat shall, } \\
\text { (a) provide sufficient resistance or dissipation, } \\
\text { (i) to minimize surface condensation on the warm side of the component or } \\
\text { assembly, } \\
\text { (ii) in conjunction with other materials and components in the assembly, to } \\
\text { minimize condensation within the component or assembly, } \\
\text { (iii) in conjunction with systems installed for space conditioning, to meet the } \\
\text { interior design thermal conditions for the intended occupancy, } \\
\text { and } \\
\text { (iv) to minimize ice damming on sloped roofs, and } \\
\text { (b) take into account the conditions on either side of the environmental separator. }\end{array}$ & $\begin{array}{l}\text { The envelope assembly } \\
\text { components needed to } \\
\text { ensure meeting adequate } \\
\text { properties in an envelope } \\
\text { assembly for heat transfer } \\
\text { resistance, air barrier } \\
\text { system, vapour barrier } \\
\text { system. The heat transfer } \\
\text { resistance layers are the } \\
\text { layers that could affect the } \\
\text { character because of their } \\
\text { thickness. The walls } \\
\text { assembly should comply with } \\
\text { a minimum thermal } \\
\text { resistance (R-value). }\end{array}$ & $\begin{array}{l}\text { A wall assembly with } \\
\text { a minimum thermal } \\
\text { resistance will be } \\
\text { thicker than the } \\
\text { original walls which } \\
\text { did not have any } \\
\text { insulation. }\end{array}$ & $\begin{array}{l}\text { Compensate the overall EUI by } \\
\text { putting heating loads on the } \\
\text { HVAC system. } \\
\text { Use insulation material which } \\
\text { provides the same thermal } \\
\text { resistance for less thickness (such } \\
\text { as XPS insulation). However, it } \\
\text { would need to conform with the } \\
\text { protection of foamed plastic in } \\
\text { Art. 3.1.4.2. }\end{array}$ \\
\hline $\begin{array}{l}\text { CDE } 5.5 \\
\text { Connection to } \\
\text { Outdoor }\end{array}$ & N/A & N/A & N/A & N/A \\
\hline
\end{tabular}


Table B- 2 Compliance with Part 5 - Environmental Separation (Continued)

\begin{tabular}{|c|c|c|c|c|}
\hline $\begin{array}{l}\text { CDE } 5.6 \\
\text { Materials } \\
\text { (wood, stone, } \\
\text { glass, concrete) }\end{array}$ & $\begin{array}{l}\text { 5.1.4.2. Resistance to Deterioration } \\
\text { (1) Except as provided in Sentence (2), materials used in building components and } \\
\text { assemblies that separate dissimilar environments, or in assemblies exposed to the } \\
\text { exterior, shall be, } \\
\text { (a) compatible with adjoining materials, and } \\
\text { (b) resistant to any mechanisms of deterioration that may reasonably be expected } \\
\text { given, } \\
\text { (i) the nature and function of the materials, } \\
\text { (ii) the exposure of the materials, and } \\
\text { (iii) the climatic conditions in which the materials } \\
\text { will be installed. } \\
\text { (2) Material compatibility and deterioration resistance are not required where it } \\
\text { can be shown that incompatibility or uncontrolled deterioration will not adversely } \\
\text { affect any of, } \\
\text { (a) the health or safety of building users, } \\
\text { (b) the intended use of the building, or } \\
\text { (c) the operation of building services. }\end{array}$ & $\begin{array}{l}\text { Materials which are sensitive } \\
\text { to water exposure such as } \\
\text { wood may be prone to } \\
\text { deterioration, which requires } \\
\text { to change either the material } \\
\text { itself or the type of material } \\
\text { used. } \\
\text { The material such as wood } \\
\text { may also require special } \\
\text { coating (varnishing) in order } \\
\text { to ensure its durability. } \\
\text { Requires glazed openings } \\
\text { assembly that prevent } \\
\text { surface condensation. } \\
\text { Taking into account the } \\
\text { outer side of the } \\
\text { environmental separator } \\
\text { would lead to choosing } \\
\text { materials that are more } \\
\text { durable for harsh winters. } \\
\text { For example, wood framed } \\
\text { windows are better with a } \\
\text { combination of vinyl exterior } \\
\text { cladding to protect the } \\
\text { frame from weather } \\
\text { damage. }\end{array}$ & $\begin{array}{l}\text { The materials used } \\
\text { are definitely } \\
\text { characters that } \\
\text { cannot be altered on } \\
\text { a FLW prairie style } \\
\text { design. } \\
\text { Wright's advice to } \\
\text { "strip the wood of } \\
\text { varnish and let it } \\
\text { alone- stain it". This } \\
\text { entails that } \\
\text { protection of } \\
\text { exterior wood was } \\
\text { not his motivation } \\
\text { to stain wood. Also, } \\
\text { the stain should be } \\
\text { transparent and } \\
\text { restrain from hiding } \\
\text { the wood grain. } \\
\text { It would be } \\
\text { unacceptable to } \\
\text { replace wood frame } \\
\text { doors and windows } \\
\text { with a vinyl cladding } \\
\text { on the exterior side. }\end{array}$ & $\begin{array}{l}\text { The floor to wall assembly can be } \\
\text { designed in a way to prove its } \\
\text { ability to withstand temporary } \\
\text { wetting by means of water } \\
\text { barriers. The challenge here is to } \\
\text { enhance these barriers in order to } \\
\text { withstand the hydrostatic } \\
\text { pressure. }\end{array}$ \\
\hline
\end{tabular}


Table B- 2 Compliance with Part 5 - Environmental Separation (Continued)

\begin{tabular}{|c|c|c|c|c|}
\hline $\begin{array}{l}\text { CDE } 3.7 \text { Roofing } \\
\text { (structure, } \\
\text { assembly) }\end{array}$ & $\begin{array}{l}\text { 5.3.1.2. Properties to Resist Heat Transfer } \\
\text { (1) Materials and components installed to provide the required resistance to heat } \\
\text { transfer or the means implemented to dissipate heat shall, } \\
\text { (a) provide sufficient resistance or dissipation, } \\
\text { (i) to minimize surface condensation on the warm side of the component or assembly, } \\
\text { (ii) in conjunction with other materials and components in the assembly, to minimize } \\
\text { condensation within the component or assembly, } \\
\text { (iii) in conjunction with systems installed for } \\
\text { space conditioning, to meet the interior design } \\
\text { thermal conditions for the intended occupancy, } \\
\text { and } \\
\text { (iv) to minimize ice damming on sloped roofs, and } \\
\text { (b) take into account the conditions on either side of the environmental separator. } \\
\text { 5.6.2.2. Accumulation and Disposal } \\
\text { (1) Where water, snow or ice can accumulate on a } \\
\text { building, provision shall be made to minimize the likelihood of hazardous conditions } \\
\text { arising from such accumulation. } \\
\text { (2) Where precipitation can accumulate on sloped or horizontal assemblies, provision } \\
\text { shall be made for drainage conforming with Section } 7.4 \text {. } \\
\text { (4) Junctions between vertical assemblies, and sloped or horizontal assemblies, shall } \\
\text { be designed and constructed to minimize the flow of water from the sloped or } \\
\text { horizontal assembly onto the vertical assembly. }\end{array}$ & $\begin{array}{l}\text { Requires a roof assembly } \\
\text { that has the specific heat } \\
\text { resistance to prevent ice } \\
\text { damming, which means its } \\
\text { thickness and slope are } \\
\text { subject to design } \\
\text { specifications. }\end{array}$ & $\begin{array}{l}\text { The slope of the roof plays } \\
\text { an essential role in the so } \\
\text { called "horizontality" of the } \\
\text { building that is a main } \\
\text { character-defining element } \\
\text { in FLW prairie style design. } \\
\text { Any design that would } \\
\text { change the horizontal shape } \\
\text { of the building would go } \\
\text { against the architect's intent } \\
\text { and philosophy. }\end{array}$ & N/A \\
\hline CDE 3.8 Ceiling & N/A & N/A & N/A & N/A \\
\hline $\begin{array}{l}\text { CDE 3.9 Chimneys } \\
\text { and Fireplaces }\end{array}$ & N/A & N/A & N/A & N/A \\
\hline $\begin{array}{l}\text { CDE } 5.10 \\
\text { Mechanical and } \\
\text { electrical } \\
\text { equipment }\end{array}$ & N/A & N/A & N/A & N/A \\
\hline CDE 5.11 Lighting & N/A & N/A & N/A & N/A \\
\hline $\begin{array}{l}\text { CDE } 5.12 \text { Natural } \\
\text { Ventilation }\end{array}$ & N/A & N/A & N/A & N/A \\
\hline $\begin{array}{l}\text { CDE } 5.13 \\
\text { Windows and } \\
\text { Openings } \\
\text { (including the } \\
\text { clerestory) }\end{array}$ & N/A & N/A & $\mathrm{N} / \mathrm{A}$ & N/A \\
\hline
\end{tabular}




\section{B3 Compliance with Part 6 - Heating, Ventilating and Air-Conditioning}

Table B- 3 Compliance with Part 6 Heating, Ventilating and Air-Conditioning

\begin{tabular}{|c|c|c|c|c|}
\hline $\begin{array}{l}\text { Character-defining } \\
\text { element (CDE) }\end{array}$ & Code section reference in Acceptable Solutions of Division B & $\begin{array}{l}\text { Implications } \\
\text { affecting the } \\
\text { character }\end{array}$ & $\begin{array}{l}\text { Impact and } \\
\text { challenges }\end{array}$ & $\begin{array}{l}\text { Code alternative compliance } \\
\text { path }\end{array}$ \\
\hline $\begin{array}{l}\text { CDE } 6.1 \text { Site Location } \\
\text { and Building } \\
\text { Orientation }\end{array}$ & N/A & $\mathrm{N} / \mathrm{A}$ & N/A & N/A \\
\hline $\begin{array}{l}\text { CDE 6.2 Building Shape } \\
\text { and Elevation }\end{array}$ & N/A & $\mathrm{N} / \mathrm{A}$ & N/A & N/A \\
\hline $\begin{array}{l}\text { CDE 6.3 Building Layout } \\
\text { and Spaces }\end{array}$ & N/A & N/A & N/A & N/A \\
\hline CDE 6.4 Proportions & $\begin{array}{l}\text { 6.2.1.1. Good Engineering Practice } \\
\text { (1) Heating, ventilating and air-conditioning systems, including related mechanical } \\
\text { refrigeration systems, shall be designed, constructed and installed to conform to good } \\
\text { engineering practice appropriate to the circumstances such as described in, } \\
\text { (a) the ASHRAE Handbooks as follows: } \\
\text { (i) Fundamentals, } \\
\text { (ii) Refrigeration, } \\
\text { (iii) HVAC Applications, } \\
\text { (iv) HVAC Systems and Equipment, and } \\
\text { (v) ANSI/ASHRAE/IESNA 90.1, "Energy Standard for Buildings Except Low-Rise } \\
\text { Residential Buildings" } \\
\text { ANSI/ASHRAE/IESNA 90.1 } \\
\text { 5. BUILDING ENVELOPE } \\
\text { 5.2 Compliance Paths } \\
\text { 5.2.1 Compliance. For the appropriate climate, space-conditioning category, and class } \\
\text { of construction, the building envelope shall comply with Section 5.1, "General"; } \\
\text { Section 5.4, "Mandatory Provisions"; Section 5.7, "Submittals"; Section 5.8, "Product } \\
\text { Information and Installation Requirements"; } \\
\text { and either } \\
\text { a. Section 5.5, "Prescriptive Building Envelope Option," provided that the fenestration } \\
\text { area does not exceed the maximum allowed by Section 5.5.4.2, or } \\
\text { b. Section 5.6, "Building Envelope Trade-Off Option." }\end{array}$ & $\begin{array}{l}\text { The building } \\
\text { envelope shall } \\
\text { comply with the } \\
\text { Prescriptive Option } \\
\text { of Section } 5.5 \text { of } \\
\text { ANSI/ASHRAE/IESNA } \\
90.1 \text { "Energy } \\
\text { Standard for } \\
\text { Buildings Except } \\
\text { Low-Rise Residential } \\
\text { Buildings". These } \\
\text { requirements } \\
\text { contain thermal } \\
\text { resistance values for } \\
\text { the roof, floor, and } \\
\text { walls. }\end{array}$ & $\begin{array}{l}\text { The impact of heat } \\
\text { transfer resistance } \\
\text { for envelope } \\
\text { requirements will } \\
\text { dictate the } \\
\text { assemble } \\
\text { components of the } \\
\text { roof, floor and } \\
\text { walls. These } \\
\text { components such as } \\
\text { insulation may } \\
\text { exceed the original } \\
\text { thickness of the } \\
\text { walls and therefore } \\
\text { affect both the } \\
\text { building interior } \\
\text { spaces, the building } \\
\text { exterior shape and } \\
\text { the proportions } \\
\text { found all around the } \\
\text { building. }\end{array}$ & $\begin{array}{l}\text { By the complying to Section } \\
\text { 5.6, "Building Envelope Trade- } \\
\text { Off Option." of ASHRAE } 90.1 \\
\text { 5.6 Building Envelope Trade- } \\
\text { Off Option } \\
5.6 .1 \text { The building envelope } \\
\text { complies with the standard if } \\
\text { a. the proposed building } \\
\text { satisfies the provisions of } \\
\text { Sections 5.1, 5.4, 5.7, and } 5.8 \\
\text { and } \\
\text { b. the envelope performance } \\
\text { factor of the proposed } \\
\text { building is less than or equal } \\
\text { to the envelope performance } \\
\text { factor of the budget building. }\end{array}$ \\
\hline $\begin{array}{l}\text { CDE } 6.5 \text { Connection to } \\
\text { Outdoor }\end{array}$ & $N / A$ & N/A & N/A & N/A \\
\hline
\end{tabular}


Table B- 3 Compliance with Part 6 Heating, Ventilating and Air-Conditioning (Continued)

\begin{tabular}{|c|c|c|c|c|}
\hline $\begin{array}{l}\text { CDE 6.6 Materials } \\
\text { (wood, stone, glass, } \\
\text { concrete) }\end{array}$ & N/A & N/A & N/A & N/A \\
\hline $\begin{array}{l}\text { CDE 6.7 Roofing } \\
\text { (structure, assembly) }\end{array}$ & N/A & N/A & N/A & N/A \\
\hline CDE 6.8 Ceiling & N/A & N/A & $\mathrm{N} / \mathrm{A}$ & N/A \\
\hline $\begin{array}{l}\text { CDE } 6.9 \text { Chimneys and } \\
\text { Fireplaces }\end{array}$ & N/A & N/A & N/A & N/A \\
\hline $\begin{array}{l}\text { CDE 6.10 Mechanical } \\
\text { and electrical } \\
\text { equipment }\end{array}$ & N/A & N/A & N/A & N/A \\
\hline CDE 6.11 Lighting & N/A & N/A & N/A & N/A \\
\hline $\begin{array}{l}\text { CDE 6.12 Natural } \\
\text { Ventilation }\end{array}$ & $\begin{array}{l}\text { 6.2.2.1. Required Ventilation } \\
\text { (1) Except as provided in Sentence (3), all buildings shall be ventilated in accordance } \\
\text { with this Part. } \\
\text { (2) Except in storage garages and repair garages covered by Article 6.2.2.3., the rates } \\
\text { at which outdoor air is supplied in buildings by ventilation systems shall be not less } \\
\text { than the rates required by ANSI/ASHRAE 62.1, "Ventilation for Acceptable Indoor Air } \\
\text { Quality". } \\
\text { 6.2.2.2. Natural Ventilation } \\
\text { (1) Except as permitted by Sentence (2), the ventilation required by Article 6.2.2.1. } \\
\text { shall be provided by mechanical ventilation except that it can be provided by natural } \\
\text { ventilation or a combination of natural and mechanical } \\
\text { ventilation in, } \\
\quad \text { (a) buildings of other than residential occupancy having an occupant load of } \\
\quad \text { not more than one person per } 40 \mathrm{~m}^{2} \text { during normal use, } \\
\text { 6.3.1.2. Masonry or Concrete Chimneys } \\
\text { (1) Rectangular masonry or concrete chimneys not more than } 12 \mathrm{~m} \text { in height shall } \\
\text { conform to Part } 9 \text { if they serve, } \\
\text { (a) appliances with a combined total rated heat output of } 120 \mathrm{~kW} \text { or less, or } \\
\text { (b) fireplaces. }\end{array}$ & $\begin{array}{l}\text { Natural ventilation } \\
\text { is in itself an } \\
\text { architectural } \\
\text { philosophy that FLW } \\
\text { used in the Banff } \\
\text { Pavilion design. It is } \\
\text { important to } \\
\text { integrate natural } \\
\text { ventilation in the } \\
\text { building as a } \\
\text { character-defining } \\
\text { element. }\end{array}$ & $\mathrm{N} / \mathrm{A}$ & N/A \\
\hline $\begin{array}{l}\text { CDE } 6.13 \text { Windows and } \\
\text { Openings (including the } \\
\text { clerestory) }\end{array}$ & N/A & N/A & N/A & N/A \\
\hline
\end{tabular}




\section{B4 Compliance with Part 9 - Housing and Small Buildings}

Table B- 4 Compliance with Part 9 - Housing and Small Buildings

\begin{tabular}{|c|c|c|c|c|}
\hline $\begin{array}{l}\text { Character-defining } \\
\text { element (CDE) }\end{array}$ & $\begin{array}{l}\text { Code section reference in Acceptable Solutions of } \\
\text { Division B }\end{array}$ & $\begin{array}{l}\text { Implications affecting the } \\
\text { character }\end{array}$ & Impact and challenges & $\begin{array}{l}\text { Code alternative } \\
\text { compliance path }\end{array}$ \\
\hline $\begin{array}{l}\text { CDE } 9.1 \text { Site } \\
\text { Location and } \\
\text { Building } \\
\text { Orientation }\end{array}$ & $\begin{array}{l}\text { 9.1.1.8. Building in Flood Plains } \\
\text { (1) Buildings constructed on flood plains shall, } \\
\text { (a) be designed and constructed in accordance with } \\
\text { good engineering practice to withstand anticipated } \\
\text { vertical and horizontal hydrostatic pressures acting on } \\
\text { the structure, and } \\
\text { (b) incorporate floodproofing measures that will } \\
\text { preserve the integrity of exits and means of egress } \\
\text { during times of flooding. }\end{array}$ & See CDE 3.1 in Table B- 1. & See CDE 3.1 in Table B- 1. & See CDE 3.1 in Table B- 1. \\
\hline $\begin{array}{l}\text { CDE } 9.2 \text { Building } \\
\text { Shape and } \\
\text { Elevation }\end{array}$ & N/A & N/A & N/A & N/A \\
\hline $\begin{array}{l}\text { CDE } 9.3 \text { Building } \\
\text { Layout and Spaces }\end{array}$ & N/A & N/A & N/A & N/A \\
\hline $\begin{array}{l}\text { CDE } 9.4 \\
\text { Proportions }\end{array}$ & N/A & N/A & N/A & N/A \\
\hline $\begin{array}{l}\text { CDE } 9.5 \\
\text { Connection to } \\
\text { Outdoor }\end{array}$ & N/A & N/A & N/A & N/A \\
\hline $\begin{array}{l}\text { CDE } 9.6 \text { Materials } \\
\text { (wood, stone, } \\
\text { glass, concrete) }\end{array}$ & N/A & $\mathrm{N} / \mathrm{A}$ & N/A & N/A \\
\hline $\begin{array}{l}\text { CDE } 9.7 \text { Roofing } \\
\text { (structure, } \\
\text { assembly) }\end{array}$ & $\begin{array}{l}\text { 9.23.13. Roof and Ceiling Framing } \\
\text { [...] } \\
\text { 9.26.3. Slope of Roof Surfaces } \\
\text { 9.26.3.1. Slope } \\
\text { (1) Except as provided in Sentences (2) and (3), the } \\
\text { slopes on which roof coverings may be applied shall } \\
\text { conform to Table 9.26.3.1. }\end{array}$ & $\begin{array}{l}\text { According to Table } 9.26 .3 .1 . \text {, } \\
\text { wood shingles roof covering } \\
\text { should have a minimum slope } \\
\text { of } 1 \text { in } 4 .\end{array}$ & $\begin{array}{l}\text { The current slope of the roof is approximately } 1 / 6 \\
\text { based on the plans which is less than the minimum } \\
\text { requirement. (See Figure } 32 \text { and Figure } 33 \text { ) An } \\
\text { increase in the slope of the roof will change the } \\
\text { horizontality and shape of the building. }\end{array}$ & N/A \\
\hline CDE 9.8 Ceiling & N/A & N/A & N/A & N/A \\
\hline $\begin{array}{l}\text { CDE } 9.9 \text { Chimneys } \\
\text { and Fireplaces }\end{array}$ & $\begin{array}{l}\text { 9.21.2.5. Fireplace Chimneys } \\
\text { (1) The size of a chimney flue serving a masonry } \\
\text { fireplace shall be within the allowable range specified } \\
\text { in Table 9.21.2.5.A. or Table 9.21.2.5.B. }\end{array}$ & $\begin{array}{l}\text { Changing the layout or size of } \\
\text { components will affect the } \\
\text { original character. }\end{array}$ & $\begin{array}{l}\text { The impact is seen on the proportions, shape and } \\
\text { layout of the building as well as the interior look. }\end{array}$ & N/A \\
\hline
\end{tabular}


Table B- 4 Compliance with Part 9 - Housing and Small Buildings (Continued)

\begin{tabular}{|c|c|c|c|c|}
\hline $\begin{array}{l}\text { CDE } 9.10 \\
\text { Mechanical and } \\
\text { electrical } \\
\text { equipment }\end{array}$ & N/A & N/A & N/A & N/A \\
\hline CDE 9.11 Lighting & N/A & N/A & N/A & N/A \\
\hline $\begin{array}{l}\text { CDE } 9.12 \text { Natural } \\
\text { Ventilation }\end{array}$ & N/A & N/A & N/A & N/A \\
\hline $\begin{array}{l}\text { CDE } 9.13 \text { Windows } \\
\text { and Openings } \\
\text { (including the } \\
\text { clerestory) }\end{array}$ & $\begin{array}{l}\text { 9.7.3.3. Thermal Characteristics of Windows, Doors } \\
\text { and Skylights } \\
\text { (3) Windows, doors and skylights, with or without } \\
\text { storm doors or sash, that are installed in buildings } \\
\text { where the intended use of the interior space will not } \\
\text { result in high moisture generation shall have a } \\
\text { maximum thermal transmittance (U-value) or } \\
\text { minimum temperature index (I) in accordance with } \\
\text { Table 9.7.3.3. } \\
\text { Where the U-value in this Table differs from the U- } \\
\text { value provided in MMAH Supplementary Standard SB- } \\
\text { 10, "Energy Efficiency Requirements" or MMAH } \\
\text { Supplementary Standard SB-12, "Energy Efficiency for } \\
\text { Housing", the most restrictive U-value shall apply. }\end{array}$ & $\begin{array}{l}\text { The U-value which requires } \\
\text { sometimes double or triple } \\
\text { pane windows will affect the } \\
\text { glass design that is typical to } \\
\text { FLW windows. }\end{array}$ & $\begin{array}{l}\text { The design of the patterns is important to } \\
\text { characterize a specific FLW building. The ability of } \\
\text { glass to modify light was, in his view, the root of its } \\
\text { beauty as a visible substance [54]. Double and } \\
\text { triple pane glazing will essentially modify the glass } \\
\text { look. }\end{array}$ & $\begin{array}{l}\text { Try to avoid having double } \\
\text { or triple pane by } \\
\text { compensating energy in } \\
\text { another building system. }\end{array}$ \\
\hline
\end{tabular}




\section{REFERENCES}

[1] A. Huang and Y.-T. Leong, "Banff Pavilion Architectural Modelling," Toronto, 2020.

[2] International Council on Monuments and Sites (ICOMOS), "The Nara Document on Authenticity (1994)," p. 3, 1994, [Online]. Available: https://www.icomos.org/charters/nara-e.pdf.

[3] International Council on Monuments and Sites (ICOMOS), "International Charter For The Conservation And Restoration Of Monuments And Sites (The Venice Charter 1964)," Venice, 1964. [Online]. Available: https://www.icomos.org/charters/venice_e.pdf.

[4] H. Stovel, "The Riga Charter on Authenticity and Historical Reconstruction in Relationship to Cultural Heritage: Riga, Latvia, October 2000," Conserv. Manag. Archaeol. Sites, vol. 4, no. 4, pp. 241-244, 2001, doi: 10.1179/135050301793138173.

[5] International Council on Monuments and Sites (ICOMOS), International Charters for Conservation and Restoration. Paris: Monuments et Sites, 2004.

[6] International Council on Monuments and Sites (ICOMOS), "The Burra Charter: The Australia ICOMOS Charter for Places of Cultural Significance," p. 12, 2013, [Online]. Available: https://australia.icomos.org/publications/charters/.

[7] Canada's Historic Places, "Standards and Guidelines for the Conservation of Historic Places in Canada," 2010. doi: R62-343/2010E-PDF.

[8] J. Bold and R. Pickard, "Reconstructing Europe: The Need for Guidelines," Hist. Environ. Policy Pract., vol. 4, no. 2, pp. 105-128, 2013, doi: 10.1179/1756750513z.00000000030.

[9] J. Bold, P. Larkham, and R. Pickard, Authentic Reconstruction: Authenticity, Architecture and the Built Heritage. London: Bloomsbury Academic, 2017.

[10] National Research Council Canada (NRCC), "National Building Code - 2019 Alberta Edition, NBC(AE)," 2019. https://nrc.canada.ca/en/certifications-evaluations-standards/codescanada/codes-canada-publications/national-building-code-2019-alberta-edition-nbcae (accessed Apr. 20, 2020).

[11] J. M. Fitch, Historic Preservation: Curatorial Management of the Built World. Charlottesville: London : University of Virginia Press, 1990. 
[12] Anne E. Grimmer, "The Secretary of the Interior's Strandards for the Treatment of Historic Properties With Guidelines For Preserving, Rehabilitating, Restoring \&amp; Reconscructing Historic Buildings," Washington D.C., 2017. [Online]. Available: https://www.nps.gov/tps/standards/treatment-guidelines-2017.pdf.

[13] J. Jokilehto, "Reconstruction in the Word Heritage Context," Eur. Assoc. Archit. Educ., pp. 1-13, 2013, [Online]. Available: https://engagingconservationyork.files.wordpress.com/2014/02/reconstruction-in-wh-contextrev.pdf.

[14] K. Weiler, Authenticity In Architectural Heritage Conservation: Discourses, Opinions, Experiences In Europe, South and East Asia. Springer-Verlag/Sci-Tech/Trade, 2016.

[15] J. Ruskin, "The Lamp of Memory," in The Seven Lamps of Architecture, London: Smith, Elder, and Co., 1849, pp. $162-182$.

[16] UNESCO, "Recommendation concerning the Safeguarding and Contemporary Role of Historic Areas," 1976. URL_ID=13133\&URL_DO=DO_TOPIC\&URL_SECTION=201.html (accessed Apr. 20, 2020).

[17] ICOMOS New Zealand, "ICOMOS New Zealand Charter for the Conservation of Places of Cultural Heritage Value," Auckland, 2010. [Online]. Available: http://icomos.org.nz/wpcontent/uploads/2016/08/NZ_Charter.pdf.

[18] ICOMOS National Committees of the Americas, "The Declaration of San Antonio (1996)," 2011. https://www.icomos.org/en/charters-and-texts/179-articles-en-francais/ressources/chartersand-standards/188-the-declaration-of-san-antonio (accessed Apr. 20, 2020).

[19] D. Spurr, "Architecture and Modern Literature - Figures of Ruin and Restoration: Ruskin and Violletle-Duc," Univ. Michigan Press, no. 2012, 1994, [Online]. Available: https://www.jstor.org/stable/j.ctt1qv5nb5.9.

[20] The American Heritage Dictionary of the English Language, "au-then·tic," Houghton Mifflin Harcourt Publishing Company, 2020. https://ahdictionary.com/word/search.html?q=authentic (accessed Apr. 20, 2020).

[21] D. Mersom, "Story of cities \#28: how postwar Warsaw was rebuilt using 18th century paintings," 
2016. https://www.theguardian.com/cities/2016/apr/22/story-cities-warsaw-rebuilt-18thcentury-paintings (accessed Apr. 20, 2020).

[22] S. J. Chung, "East Asian Values in Historic Conservation," J. Archit. Conserv., vol. 11, no. 1, pp. 5570, 2005, doi: 10.1080/13556207.2005.10784935.

[23] UNESCO, "The Yamato Declaration on Integrated Approaches for Safeguarding Tangible and Intangible Cultural Heritage," Paris, 2004. [Online]. Available: https://unesdoc.unesco.org/ark:/48223/pf0000137634.

[24] D. Lowenthal, The Heritage Crusade and the Spoils of History. 1998.

[25] B. Li, "Stone Sutra Ravine," 2012. https://www.flickr.com/photos/boshun_li/13840276544 (accessed Apr. 20, 2020).

[26] J. Miranda, "Grand Shrine of Ise," 2018. https://www.spacesmith.com/blog/grand-shrine-of-ise (accessed Apr. 20, 2020).

[27] Z. Aygen, International heritage and historic building conservation: Saving the world's past. 2013.

[28] M. Gray, “Djenne, Mali,” 2018. https://sacredsites.com/africa/mali/djenne.html (accessed Apr. 20, 2020).

[29] H. Stovel, "Origins and Influence of the Nara Document on Authenticity," APT Bull. J. Preserv. Technol., vol. 39, no. 2, pp. 9-17, 2008.

[30] D. Adams and M. Carwardine, Last Chance To See. 2013.

[31] T. Bricker, "Golden Pavilion Temple in Kyoto, Japan," 2017. https://www.travelcaffeine.com/golden-pavilion-temple-kyoto-japan-tips/ (accessed Apr. 20, 2020).

[32] MIMOA, “Bauhaus Masters' Houses: Gropius House, Dessau, 1926," 2019. https://www.pinterest.ca/pin/738801513841060057/?autologin=true\&nic=1a (accessed Apr. 20, 2020).

[33] J. Cooper, "Staircase, Kandinsky/Klee Masters' house, Dessau, July 2010," 2010. https://www.flickr.com/photos/eastgermanpics/4866979898 (accessed Apr. 20, 2020).

[34] Merriam-Webster Dictionary, “Definition of authentic," 2020. https://www.merriam- 
webster.com/dictionary/authentic (accessed Apr. 20, 2020).

[35] National Board of Antiquities, "Can we learn from the heritage lost in a fire ? Experiences and practises on the fire protection of historic buildings in Finland, Norway and Sweden," p. 80, 2004.

[36] N. Mafi, "11 Beautiful Examples of When Historic and Modern Architecture Come Together," 2020. https://www.architecturaldigest.com/gallery/beautiful-examples-historic-modern-architecturecome-together (accessed Apr. 20, 2020).

[37] T. Parmenter, "York Minster shows how cathedrals can be restored after fires," 2019. https://news.sky.com/story/york-minster-shows-how-cathedrals-can-be-restored-after-fires11695738 (accessed Apr. 20, 2020).

[38] WEB Gallery of Art, "Architectural works (13th century, Britain)," 2020. https://www.wga.hu/html_m/zzzarchi/13c/4/4york02.html (accessed Apr. 20, 2020).

[39] C. W. D. Green, "Records of Buildings. Supplement IV. The Roofs of York Minster," J. Soc. Archit. Hist. Gt. Britain, vol. 8, pp. 105-124, 1965, doi: 10.2307/1568277.

[40] A. M. Thomson, "South Transept Vault, York Minster," 2014. https://www.flickr.com/photos/amthomson/15759775596 (accessed Apr. 20, 2020).

[41] J. Hammond, "The Story of Uppark," National Trust Images, 2020. https://www.nationaltrust.org.uk/uppark-house-and-garden/features/the-story-of-uppark (accessed Apr. 20, 2020).

[42] E. E. Hocker, C. Rowell, and J. M. Robinson, "Uppark Restored," APT Bull., 1998, doi: $10.2307 / 1504549$.

[43] R. Truman and A. von Einsiedel, "The fire at Uppark," National Trust Images, 2020. https://www.nationaltrust.org.uk/uppark-house-and-garden/features/the-fire-at-uppark (accessed Apr. 20, 2020).

[44] P. Pintos, "Battersea Arts Centre / Haworth Tompkins," 2018. https://www.archdaily.com/910491/battersea-arts-centre-haworth-tompkins (accessed Apr. 20, 2020).

[45] F. Howarth, "RETURNING OF BATTERSEA ARTS CENTRE ORGAN MARKS THE END OF $\begin{array}{llll}\text { TRANSFORMATION } & \text { BY HAWORTH } & \end{array}$ 
https://www.metalocus.es/en/news/returning-battersea-arts-centre-organ-marks-endtransformation-haworth-tompkins (accessed Apr. 20, 2020).

[46] J. G. Soriano, C. L. Albert, and C. L. Albert, "Building Repetition Through History Motivations And Implications," 2020. https://www.mascontext.com/issues/21-repetition-spring-14/buildingrepetition-through-history-motivations-and-implications/ (accessed Apr. 20, 2020).

[47] THE MILLION IMAGE DATABASEUP, “Introducing 3D," 2020. https://www.millionimage.org.uk/introducing-3d/ (accessed Apr. 20, 2020).

[48] A. Klingbeil, "Team of professors join effort to rebuild Frank Lloyd Wright pavilion in Banff," 2017. http://calgaryherald.com/news/local-news/revival-of-frank-lloyd-wright-pavilion-in-banffmoving-forward-with-help-from-ryerson-university-professors (accessed Apr. 20, 2020).

[49] Public Archives Canada, "Frank Lloyd Wright's Banff Pavilion Original Plans (0017150).," Ottawa, 2020.

[50] River Forest Tennis Club, "Historical Timeline," 2020. https://www.rftc.org/historical-timeline (accessed Apr. 20, 2020).

[51] T. Lambert, "Banff considers rebuilding pavilion designed by Frank Lloyd Wright," 2016. http://calgaryherald.com/news/local-news/banff-considers-rebuilding-pavilion-designed-byfrank-lloyd-wright (accessed Apr. 20, 2020).

[52] D. Maddex, Wright-Sized Houses: Frank Lloyd Wright's Solutions for Making Small Houses Feel Big. Harry N. Abrams Inc., 2003.

[53] K. Smith, "Rebuilding the Frank Lloyd Wright Pavilion: A Collaborative Approach," p. 15, 2018.

[54] T. L. Patterson, Frank Lloyd Wright and the Meaning of Materials. Van Nostrand Reinhold, 1994.

[55] Canadian Architect, "Frank Lloyd Wright Revival Initiative proceeds with next phase of Banff Pavilion rebuild," 2016. https://www.canadianarchitect.com/frank-Illoyd-wright-initiative-banff/ (accessed Apr. 20, 2020).

[56] Government of Alberta, "Building," 2016. http://municipalaffairs.gov.ab.ca/cp_building (accessed Apr. 20, 2020).

[57] Government of Alberta, "Building codes and standards," 2020. https://www.alberta.ca/building- 
codes-and-standards.aspx (accessed Apr. 20, 2020).

[58] Ontario's Ministry of Municipal Affairs and Housing, "Building Code Act, 1992, S.O. 1992, c. 23," 2019. https://www.ontario.ca/laws/statute/92b23\#BK25 (accessed Apr. 20, 2020).

[59] American Society of Heating Refrigerating and Air-Conditioning Engineers (ASHRAE), "Energy Standard for Buildings Except Low-Rise Residential Buildings (90.1)," 2013. doi: ISSN 1041-2336.

[60] National Research Council Canada (NRCC), "National Energy Code for Buildings (NECB) Overview," p. 152, [Online]. Available: https://www.alberta.ca/assets/documents/ma-national-energy-codefor-buildings-overview.pdf.

[61] Ontario's Ministry of Municipal Affairs and Housing, "Energy Efficiency Requirements Supplementary Standard SB-10," 2012.

[62] G. Finch, J. Wang, and D. Ricketts, "Guide for Designing Energy-Efficient Building Enclosures for Wood-Frame Multi-Unit Residential Buildings in Marine to Cold Climate Zones in North America," 2011.

[63] Building Science Corporation, "Info-502: Temperature Dependence of R-values in Polyisocyanurate Roof Insulation," 2013. .

[64] Building Science Corporation, "ETW: Wall - 2x6 Advanced Frame Wall Construction," 2014. https://www.buildingscience.com/documents/enclosures-that-work/high-r-value-wallassemblies/advanced-frame-wall-construction (accessed Apr. 20, 2020).

[65] Building Science Corporation, "ETW: Wall - Spray Foam Wall Construction," 2014. https://www.buildingscience.com/documents/enclosures-that-work/high-r-value-wallassemblies/high-r-wall-spray-foam-wall-construction (accessed Apr. 20, 2020).

[66] Building Science Corporation, "ETW: Wall - 2x6 Advanced Frame Wall Construction with Mineral Fiber Insulation Board," 2014. https://www.buildingscience.com/documents/enclosures-thatwork/high-r-value-wall-assemblies/high-r-wall-advanced-frame-mineral-fiber-board (accessed Apr. 20, 2020).

[67] Structural Insulated Panel Association, "SIP R-Values (Calculated R-Values)," 2020. .

[68] Building Science Corporation, "ETW: Wall - SIPs Wall Construction," 2014. https://www.buildingscience.com/documents/enclosures-that-work/high-r-value-wall- 
assemblies/high-r-wall-sips-wall-construction (accessed Apr. 20, 2020).

[69] J. Lstiburek, "RR-0404: Roof 2004. https://www.buildingscience.com/documents/reports/rr-0404-roof-design/view.

[70] J. Lstiburek, "BSI-083: Mea Culpa Roofs *," 2014. .

[71] Chicago Tribune, "Options considered for preserving Mies van der Rohe's iconic Farnsworth House from flooding.," 2014. https://www.pinterest.ca/pin/420523683928521959/ (accessed Apr. 20, 2020).

[72] Government of Ontario, “Ontario Building Code 2012," no. 1, pp. 9-10, 2014.

[73] Mehaffey J.R., "Combustibility of Building Materials," NRC Publ. Arch. Rec., 1987, doi: https://doi.org/10.4224/20328410. 